\title{
Work Plan for Focused Feasibility Study of the Toxic Burning Pits Area at J-Field, Aberdeen Proving Ground, Maryland
}

Environmental Assessment Division Argonne National Laboratory

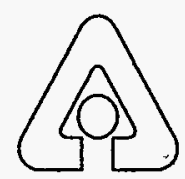

Operated by The University of Chicago, under Contract W-31-109-Eng-38, for the'

- United States Department of Energy 


\section{Argonine National Laboratory}

Argonne National Laboratory, with facilities in the states of Illinois and Idaho, is owned by the United States. Govemment, and operated by the University of Chicago under the provisions of a contract with the Department of Energy.

This technical memo is a product of Argonne's Environmental Assessment Division (EAD). For information on the division's scientific and engineering activities, contact:

Director, Environmental Assessment Division

Argonne National Laboratory

Argonne, Illinois 60439-4815

Telephone (708) 252-3107

Presented in this technical memo are preliminary results of ongoing work or work that is more limited in scope and depth than that described in formal reports issued by the EAD.

\section{Publishing Support Services}

Publishing support services próvided by Argonne's information and Publishing Division.

\section{Disclaimer}

This report was prepared as an account of work sponsored by an agency of the United States Govemment. Neither the United States Government nor

any agency thereof, nor any of their employees, makes any warranty, express or implied, or assumes any legal liability'or responșibility for the accuracy, completeness, or usefulness of any information, apparatus, product, or process disclosed, or represents that its use would not jifringe privately owned rights. Reference herein to any specific commercial. product, process, or serviçe by trade name, trademark, manufacturer, or ótherwise, does not necessarily constitute or imply its endorsement, recommendation, or favoring by the United States Govemment or any agency thereof. The views and opinions of authors expressed herein do not necessarily state or reflect those of the United'States Government or any agency thereof.

Reproduced directly from the best available copy.

Available to DOE and DOE contractors from the Office - of Scientific and Technical Information, P.O. Box 62, Oák Ridge, TN 37831; prices available from (615) 576-8401.

Available-to the public from the National Technical Information Service, U.S. Department of Commerce, '5285, Port Royal Road, Springfield, VA 22161. 


\section{Work Plan for Focused Feasibility Study of the Toxic Burning Pits Area at J-Field, Aberdeen Proving Ground, Maryland}

by C. Biang, P. Benioff, L. Martino, and T. Patton

Environmental Assessment Division,

Argonne National Laboratory, 9700 South Cass Avenue, Argonne, Illinois 60439

March 1995

Work sponsored by U.S. Army Aberdeen Proving Ground, Directorate of Safety, Health, and Environment

UISTRIBUTION OF THIS DOCUMENT IS UNLIMITEO 
This report is printed on recycled paper. 


\section{DISCLAIMER}

Portions of this document may be illegible in electronic image products. Images are produced from the best available original document. 


\section{CONTENTS}

FOREWORD $\ldots \ldots \ldots \ldots \ldots \ldots \ldots \ldots \ldots \ldots \ldots \ldots \ldots \ldots \ldots \ldots$ vii

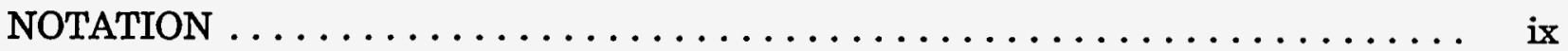

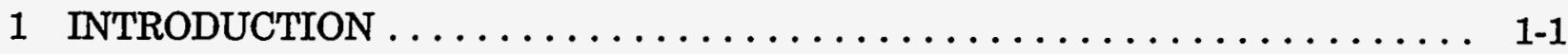

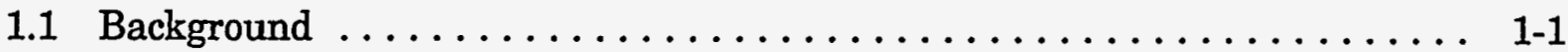

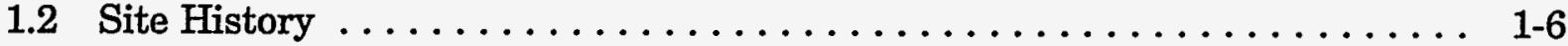

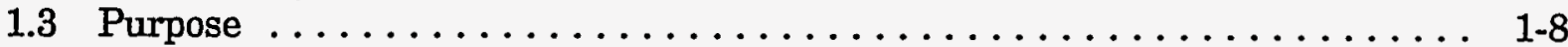

1.4 Report Organization . . . . . . . . . . . . . . . . . . . . . 1-9

2 ENVIRONMENTAL CONDITIONS $\ldots \ldots \ldots \ldots \ldots \ldots \ldots \ldots \ldots \ldots \ldots \ldots$

2.1 Environmental Setting . . . . . . . . . . . . . . . . . . . $2-1$

2.1.1 Surface Features ....................... 2-1

2.1 .2 Climate ............................. $2-1$

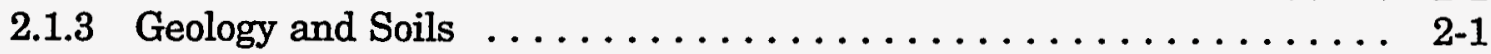

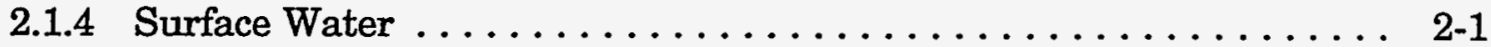

2.1 .5 Groundwater .......................... $2-4$

2.1 .6 Ecology ............................... $2-6$

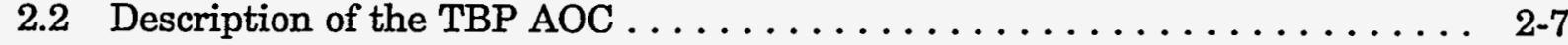

2.3 Preliminary Evaluation of the TBP AOC $\ldots \ldots \ldots \ldots \ldots \ldots \ldots \ldots$

2.3.1 Types of Waste Present . . . . . . . . . . . . . . . . . 2-9

2.3.2 Types of Contaminants Present . . . . . . . . . . . . . . . . 2-9

2.3.3 Potential Pathways of Contaminant Migration . . . . . . . . . . 2 2-39

3 FOCUSED FEASIBILITY STUDY TASKS . . . . . . . . . . . . . . 3-1

3.1 Task 1: Development of Remedial Action Objectives

and Response Actions . . . . . . . . . . . . . . . . . . . . . 3-1

3.1.1 Development of Remedial Action Objectives . . . . . . . . . . . . 3-1

3.1.2 Development of General Response Actions . . . . . . . . . . . . . . 3-2

3.2 Task 2: Identification of Remedial Action

Technologies and Assembly of Alternatives . . . . . . . . . . . . . 3-5

3.3 Task 3: Screening of Remedial Action Alternatives . . . . . . . . . . 3-7

3.4 Task 4: Performance of Treatability Studies . . . . . . . . . . . . 3-8

3.5 Task 5: Detailed Analysis of Alternatives $\ldots \ldots \ldots \ldots \ldots \ldots \ldots \ldots$

3.5.1 Subtask 5.1: Detailed Development of Remaining

Alternatives ........................... 3-8

3.5.2 Subtask 5.2: Evaluation of Alternatives against

Regulatory Criteria . . . . . . . . . . . . . . . . . . . . . 3-9

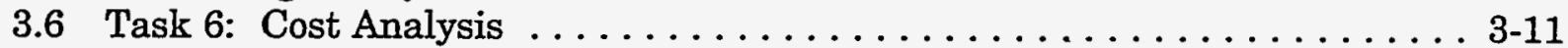

3.6.1 Subtask 6.1: Capital Costs . . . . . . . . . . . . . . . . 3-11

3.6.2 Subtask 6.2: Operating and Maintenance Costs . . . . . . . . . 3-12

3.6.3 Subtask 6.3: Present-Worth Analysis . . . . . . . . . . . . . 3-13

3.6.4 Subtask 6.4: Sensitivity Analysis . . . . . . . . . . . . . . . 3-13

3.6.5 Subtask 6.5: Cost Analysis Summary . . . . . . . . . . . . 3-13 


\section{CONTENTS (Cont.)}

3.7 Task 7: Selection of Preferred Alternative $\ldots \ldots \ldots \ldots \ldots \ldots \ldots \ldots .13$

3.8 Task 8: Report Preparation . . . . . . . . . . . . . . . . . . 3-14

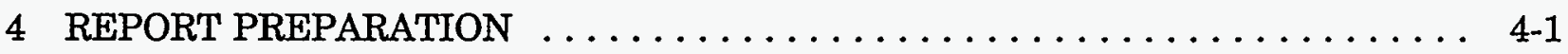

4.1 Draft Focused Feasibility Study Report $\ldots \ldots \ldots \ldots \ldots \ldots \ldots \ldots$ 4 4

4.1.1 Section 1: Introduction $\ldots \ldots \ldots \ldots \ldots \ldots \ldots \ldots \ldots \ldots, 4-1$

4.1.2 Section 2: Site Background . . . . . . . .

4.1.3 Section 3: Remedial Action Objectives .............. 4-1

4.1.4 Section 4: Identification and Screening of Technologies . . . . . 4 4-1

4.1.5 Section 5: Development and Screening of Preliminary

Alternatives . ....................... $4-1$

4.1.6 Section 6: Detailed Analysis of Alternatives ............ 4-3

4.1.7 Section 7: Comparative Analysis of Alternatives . . . . . . . . . 4-4

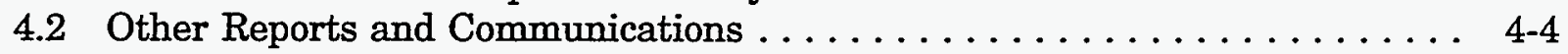

4.2.1 Monthly Progress Reports . . . . . . . . . . . . . . . .

4.2.2 Responsiveness Summary $\ldots \ldots \ldots \ldots \ldots \ldots \ldots \ldots \ldots \ldots$ 4-5

5 REFERENCES . . . . . . . . . .

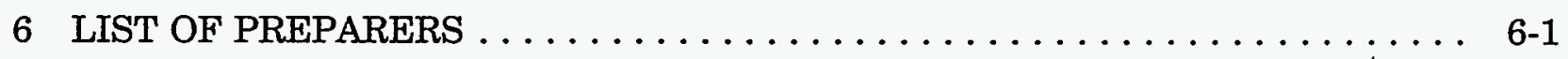

\section{TABLES}

1.1 Summary of Disposal Activities at J-Field $\ldots \ldots \ldots \ldots \ldots \ldots \ldots \ldots \ldots$

2.1 Summary of Previous Investigations at J-Field $\ldots \ldots \ldots \ldots \ldots \ldots \ldots \ldots$

2.2 Analytical Results for Analysis of Soil Samples from the Toxic Burning Pits AOC Main Burning Pits, January $1983 \ldots \ldots \ldots \ldots \ldots .2-17$

2.3 Analytical Results for Analysis of Soil Samples J1-J20 from the Toxic Burning Pits, 1986 . . . . . . . . . . . . . . . . . . . . . . 2-19

2.4 Analytical Results for Analysis of Soil Samples from the Toxic Burning Pits Area, April 1991

2.5 Analytical Results for Target Compound List Analytes in Selected Soil Samples from the Toxic Burning Pits, 1992

2.6 Analytical Results for Target Analyte List Analytes in Selected Soil Samples from the Toxic Burning Pits, $1992 \ldots \ldots \ldots \ldots \ldots \ldots \ldots .2-26$

2.7. Analytical Results for Surface Water Samples from the Toxic Burning Pits Area, 1986 


\section{TABLES (Cont.)}

2.8 Analytical Results for Groundwater from the P-Series

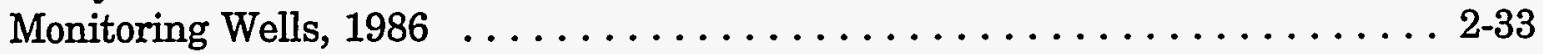

2.9 Analytical Results for Selected Inorganic Compounds, TOC, and

Metals in Groundwater from the Toxic Burning Pits, 1990 . . . . . . . . . 2-34

2.10 Analytical Results for Selected VOCs in Groundwater from the

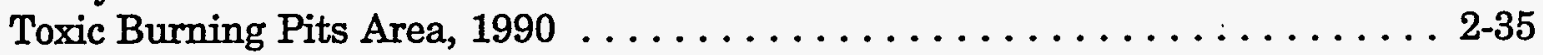

2.11 Analytical Results for Organosulfur and Explosives-Related

Compounds in Groundwater from the Toxic Burning Pits Area, 1990 . . . . . 2 2-37

2.12 Analytical Results for Selected VOCs in Groundwater Samples from

the Toxic Burning Pits Area, $1992 \ldots \ldots \ldots \ldots \ldots \ldots \ldots \ldots \ldots \ldots .2-38$

3.1 Response Action Categories and Associated Technologies and

Process Options . . . . . . . . . . . .

3.2 Site Characteristics That May Affect Response Actions $\ldots \ldots \ldots \ldots \ldots$ 3-5

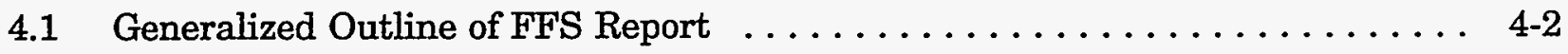

\section{FIGURES}

1.1 Location of J-Field in the Edgewood Area at APG $\ldots \ldots \ldots \ldots \ldots \ldots \ldots$ 1-2

1.2 Location of J-Field and Major Associated Features on the

Gunpowder Neck Peninsula ....................... 1-4

1.3 Locations of Areas of Concern and Principal Site Features at J-Field . . . . 1-5

2.1 Topography of the J-Field Area $\ldots \ldots \ldots \ldots \ldots \ldots \ldots \ldots \ldots \ldots \ldots \ldots \ldots \ldots .2$

2.2 Locations of Woods, Marshes, Ponds, Open Fields, and Streams

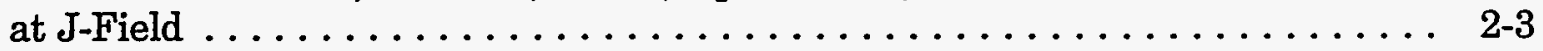

2.3 Groundwater Flow in the Surficial Aquifer, November $1989 \ldots \ldots \ldots \ldots$. . . 2-5

2.4 The Toxic Burning Pits AOC at J-Field $\ldots \ldots \ldots \ldots \ldots \ldots \ldots \ldots \ldots .2-8$

2.5 Relative Contours for all Soil-Gas Parameters at the

Toxic Burning Pits Area ........................... 2-13

2.6 Relative Contours for Alkanes in Soil Gas from the

Toxic Burning Pits Area ......................... 2-14 


\section{FIGURES (Cont.)}

2.7 Relative Contours for Combined TRCLE and TCLEE at the Toxic

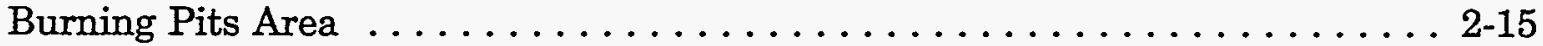

2.8 Relative Contours for Heavy Aromatics in Soil Gas from the Toxic Burning Pits Area ............................ 2-16

2.9 Locations in the Toxic Burning Pits Area where Surface Soil and Surface Water Samples Were Collected during the 1986 RCRA

Facility Assessment . . . . . . . . . . . . . . . . . . . $2-18$

2.10 Locations where Soil Samples Were Collected by the USGS in $1991 \ldots \ldots \ldots$. 2-21

2.11 Locations of Soil Sampling Conducted by Weston in 1992 in the Toxic Burning Pits AOC ............................. 2-23

2.12 Locations of Surface Water Samples Collected at J-Field in $1988 \ldots \ldots \ldots \ldots$. . .28

2.13 Locations of Surface Water and Sediment Samples Collected at

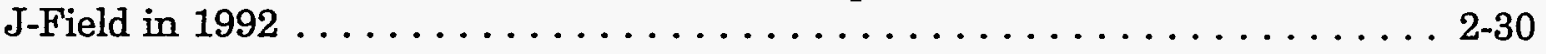

2.14 Locations of All Wells Installed at J-Field $\ldots \ldots \ldots \ldots \ldots \ldots \ldots \ldots .2-31$

2.15 Contours of TRCLE Concentrations in the Surficial Aquifer $\ldots \ldots \ldots \ldots \ldots 2-36$ 


\section{FOREWORD}

This document presents the Work Plan for the Focused Feasibility Study of the Toxic Burning Pits Area at J-Field for the field work to be conducted as part of a remedial investigation/feasibility study (RI/FS) to be carried out at J-Field, Aberdeen Proving Ground, Maryland, pursuant to the Comprehensive Environmental Response, Compensation, and Liability Act, as amended. The RI/FS is to be conducted for the U.S. Army under the direction of the Directorate of Safety, Health, and Environment, Aberdeen Proving Ground. This report is one in a series of documents being prepared to define the plans for RI/FS activities at J-Field. Other documents in this series include a Remedial Investigation Work Plan (Benioff et al. 1995a); a Field Sampling Plan (Benioff et al. 1995b); and a Quality Assurance Project Plan (Prasad et al. 1995). Two other documents - an Ecological Risk Assessment Work Plan and a Work Plan for the Feasibility Study - are in preparation. 


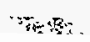




\section{NOTATION}

\section{ACRONYMS AND ABBREVIATIONS}

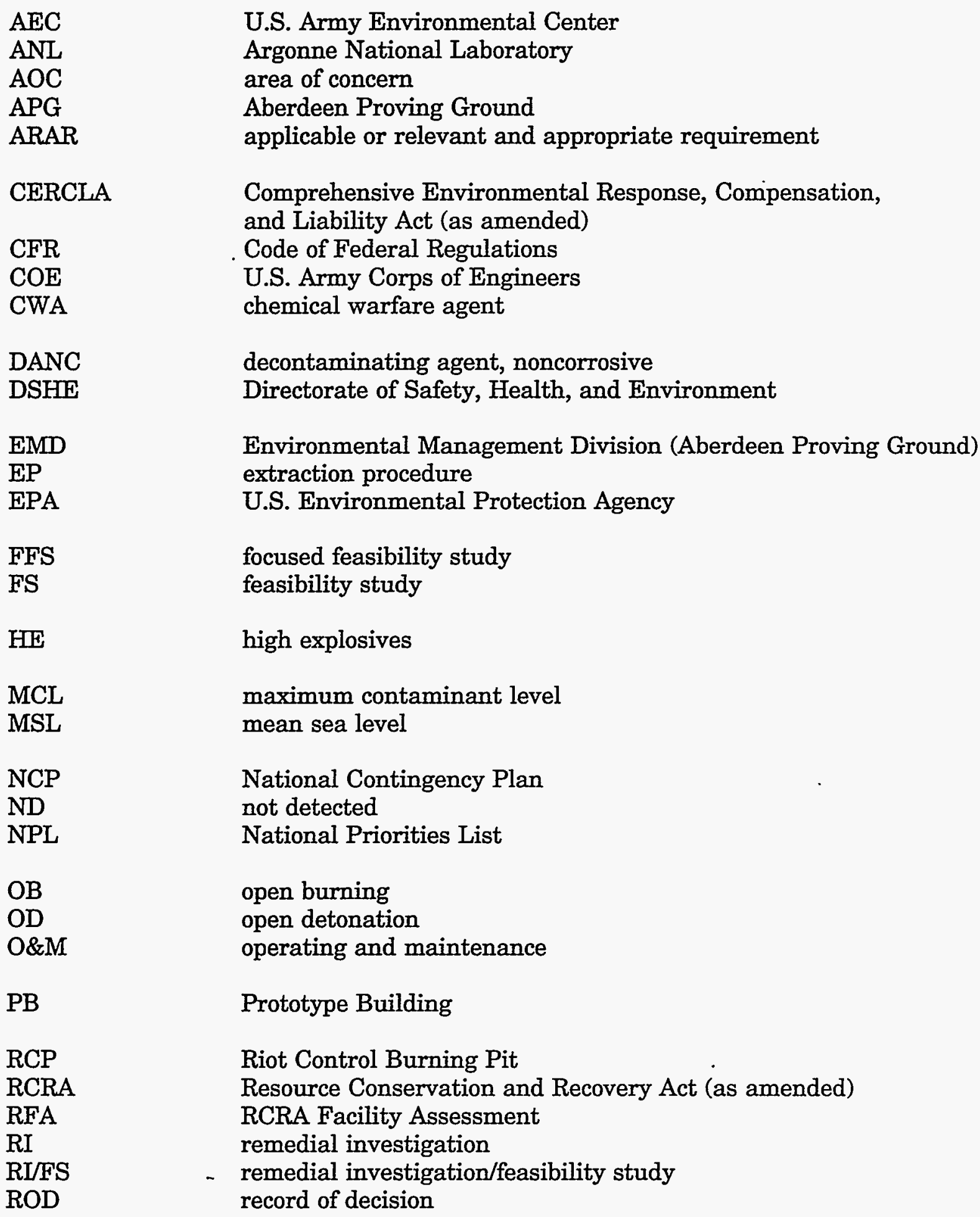




$\begin{array}{ll}\text { RPDG } & \begin{array}{l}\text { Robins Point Demolition Ground } \\ \text { Robins Point Tower Site }\end{array} \\ \text { SARA } & \begin{array}{l}\text { Superfund Amendments and Reauthorization Act } \\ \text { SBDG }\end{array} \\ \text { SBT } & \begin{array}{l}\text { South Beach Demolition Ground } \\ \text { South Beach Trench } \\ \text { SWMU }\end{array} \\ \text { solid waste management unit } \\ \text { TAL } & \text { Target Analyte List } \\ \text { TBD } & \text { to be determined } \\ \text { TBP } & \text { Toxic Burning Pits } \\ \text { TCL } & \text { Target Compound List } \\ \text { USAEHA } & \text { U.S. Army Environmental Hygiene Agency } \\ \text { USATHAMA } & \text { U.S. Army Toxic and Hazardous Materials Agency } \\ \text { USGS } & \text { U.S. Geological Survey } \\ \text { UXO } & \text { unexploded ordnance } \\ \text { WPP } & \text { White Phosphorus Burning Pits }\end{array}$

\section{ABBREVIATIONS FOR CHEMICALS}

BNA

C2H3CL

$\mathrm{C} 6 \mathrm{H} 6$

CHCL3

CN

CS

DCE

11DCE

12DCE

DDD

DDE

DDT

DNT

FM

FS

PCB

PETN

PWP

RDX- base neutral and acid extractable organic compounds

vinyl chloride

benzene

chloroform

chloroacetophenone

o-chlorobenzylidene malononitrile/orthochlorobenzalmalononitrile

dichloroethylene

1,1-dichloroethylene

1,2-dichloroethylene

dichlorodiphenyldichloroethane

dichlorodiphenyldichloroethylene

dichlorodiphenyltrichloroethane

dinitrotoluene

titanium tetrachloride

sulfur trioxide/chlorosulfonic acid

polychlorinated biphenyl

penta-erythritol tetranitrate

plasticized white phosphorus

hexahydro-1,3,5-trinitro-1,3,4-triazine 
TCE

$111 \mathrm{TCE}$

112TCE

TCLEA

TCLEE

TKN

TOC

TOX

trans-12DCE

TRCLE

VOC

$\mathrm{VX}$ trichloroethane

1,1,1-trichloroethane

1,1,2-trichloroethane

1,1,2,2-tetrachloroethane

tetrachloroethylene

total Kjeldahl nitrogen

total organic carbon

total organic halogens

trans-1,2-dichloroethylene

trichloroethylene

volatile organic compound

o-ethyl S-(2-diisopropylaminoethyl methylphosphonothioate) = methylphosphonothioic acid, a nerve agent

\section{UNITS OF MEASURE}

$\begin{array}{llll}{ }^{\circ} \mathrm{C} & \text { degree(s) Celsius } & \text { in. } & \text { inch(es) } \\ \mathrm{d} & \text { day(s) } & \mathrm{L} & \text { liter(s) } \\ { }^{\circ} \mathrm{F} & \text { degrees Fahrenheit } & \mathrm{lb} & \text { pound(s) } \\ \mathrm{ft} & \text { foot (feet) } & \mathrm{m} & \text { meter(s) } \\ \mathrm{ft}^{2} & \text { square foot (feet) } & \mathrm{mi} & \text { mile(s) } \\ \mathrm{g} & \text { gram(s) } & \mathrm{pCi} & \text { picocurie(s) } \\ \mathrm{kg} & \text { kilogram(s) } & \mathrm{ppb} & \text { part(s) per billion } \\ \mathrm{\mu g} & \text { microgram(s) } & \mathrm{ppm} & \text { part(s) per million } \\ \mathrm{mg} & \text { milligram(s) } & \mathrm{yd} & \text { yard(s) } \\ \mathrm{gal} & \text { gallon(s) } & & \end{array}$




\section{INTRODUCTION}

\subsection{BACKGROUND}

The Environmental Management Division (EMD) of Aberdeen Proving Ground (APG), Maryland, is conducting a remedial investigation and feasibility study (RI/FS) of the J-Field area at APG pursuant to the Comprehensive Environmental Response, Compensation, and Liability Act, as amended (CERCLA). J-Field is within the Edgewood Area of APG in Harford County, Maryland (Figure 1.1). Since World War II, activities in the Edgewood Area have included the development, manufacture, testing, and destruction of chemical agents and munitions. These materials were destroyed at J-Field by open burning ${ }^{1}$ and open detonation (OB/OD).

Considerable archival information about $J$-Field exists as a result of efforts by APG staff to characterize the hazards associated with the site. Contamination of J-Field was first detected during an environmental survey of the Edgewood Area conducted in 1977 and 1978 by the U.S. Army Toxic and Hazardous Materials Agency (USATHAMA) (predecessor to the U.S. Army Environmental Center [AEC]). As part of a subsequent USATHAMA environmental survey, 11 wells were installed and sampled at J-Field. Contamination at J-Field was also detected during a munitions disposal survey conducted by Princeton Aqua Science in 1983. The Princeton Aqua Science investigation involved the installation and sampling of nine wells and the collection and analysis of surficial and deep composite soil samples. In 1986, a Resource Conservation and Recovery Act (RCRA) permit (MD3-21-0021355) requiring a basewide RCRA Facility Assessment (RFA) and a hydrogeologic assessment of J-Field was issued by the U.S. Environmental Protection Agency (EPA). In 1987, the U.S. Geological Survey (USGS) began a two-phased hydrogeologic assessment in which data were collected to model groundwater flow at J-Field. Soil gas investigations were conducted, several well clusters were installed, a groundwater flow model was developed, and groundwater and surface water monitoring programs were established that continue today.

While APG was pursuing the investigation of J-Field under RCRA corrective action, the Edgewood Area was added to the National Priorities List (NPL) on February 21, 1990. Because of that listing, an RIFS is required for the entire Edgewood Area pursuant to Modification 2 of the RCRA Permit and a March 1990 Federal Facility Agreement between EPA Region III and the Department of the Army. The corrective action requirements of RCRA have been preempted, and J-Field is being evaluated under CERCLA.

1 Pursuant to Title 40, Code of Federal Regulations (40 CFR), Part 260.10, "open burning" means the combustion of any material without the following characteristics:

(1) Control of combustion air to maintain adequate temperature for efficient combustion,

(2) Containment of the combustion-reaction in an enclosed device to provide sufficient residence time and mixing for complete combustion, and

(3) Control of emission of the gaseous combustion products. 


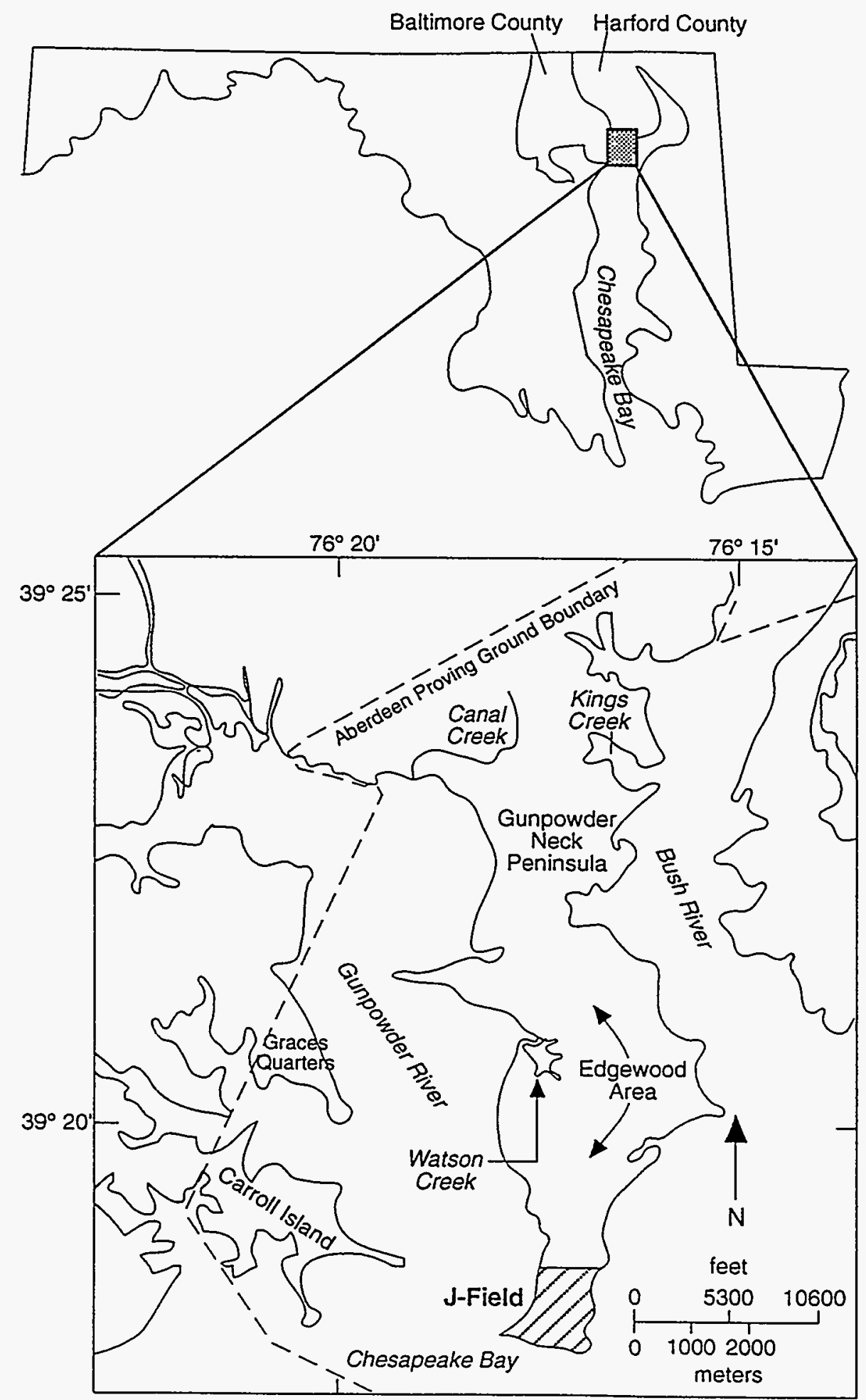

FIGURE 1.1 Location of J-Field in the Edgewood Area at APG (Source: Adapted from Hughes 1993) 
J-Field is almost flat and is covered by open fields, woods, and nontidal marshes. It encompasses about 460 acres at the southern end of the Gunpowder Neck Peninsula (Figure 1.2). The peninsula is surrounded by tidal estuaries on three sides - Gunpowder River to the west, Chesapeake Bay to the south, and Bush River to the east. For the purposes of the RI/FS, J-Field has been divided into eight geographic areas or features that are designated in this report as areas of concern (AOCs): the Toxic Burning Pits (TBP), the White Phosphorus Burning Pits (WPP), the Riot Control Burning Pit (RCP), the Robins Point Demolition Ground (RPDG), the Robins Point Tower Site (RPTS), the South Beach Demolition Ground (SBDG), the South Beach Trench (SBT), and the Prototype Building (PB) (Figure 1.3). These AOCs correspond to the eight solid waste management units (SWMUs) identified in the RCRA Facility Assessment, Edgewood Area, Aberdeen Proving Ground, MD (Nemeth 1989). Several subareas within these AOCs could represent discrete sources of contamination. The AOCs and their associated subareas are as follows:

- Toxic Burning Pits (TBP) AOC

- Main Burning Pits (consisting of a northern burning pit and a southern burning pit)

- Methylphosphonothioic Acid (VX) Burning Pit

- Mustard Burning Pit

- Pushout Area

- Liquid Smoke Disposal Pit

- Demolition Area

- Storage/Unloading Area

- Square Pit

- White Phosphorus Burning Pits (WPP) AOC

- Principal Burning Pits (consisting of a northern burning pit, a southern burning pit, and an associated bermed depression that received runoff from the northern burning pit)

- Pushout Area

- Mounded Areas

- Historic White Phosphorus Disposal Area (located south to southeast of the existing principal burning pits)

- Riot Control Burning Pit (RCP) AOC

- Burning Pit

- Pushout Area

- Robins Point Demolition Ground (RPDG) AOC

- Active Area

- Inactive Area

- Robins Point Tower Site (RPTS) AOC 


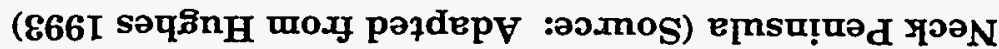

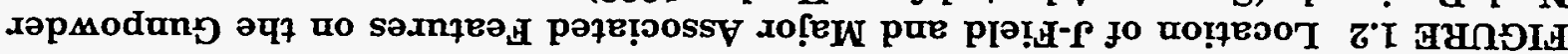

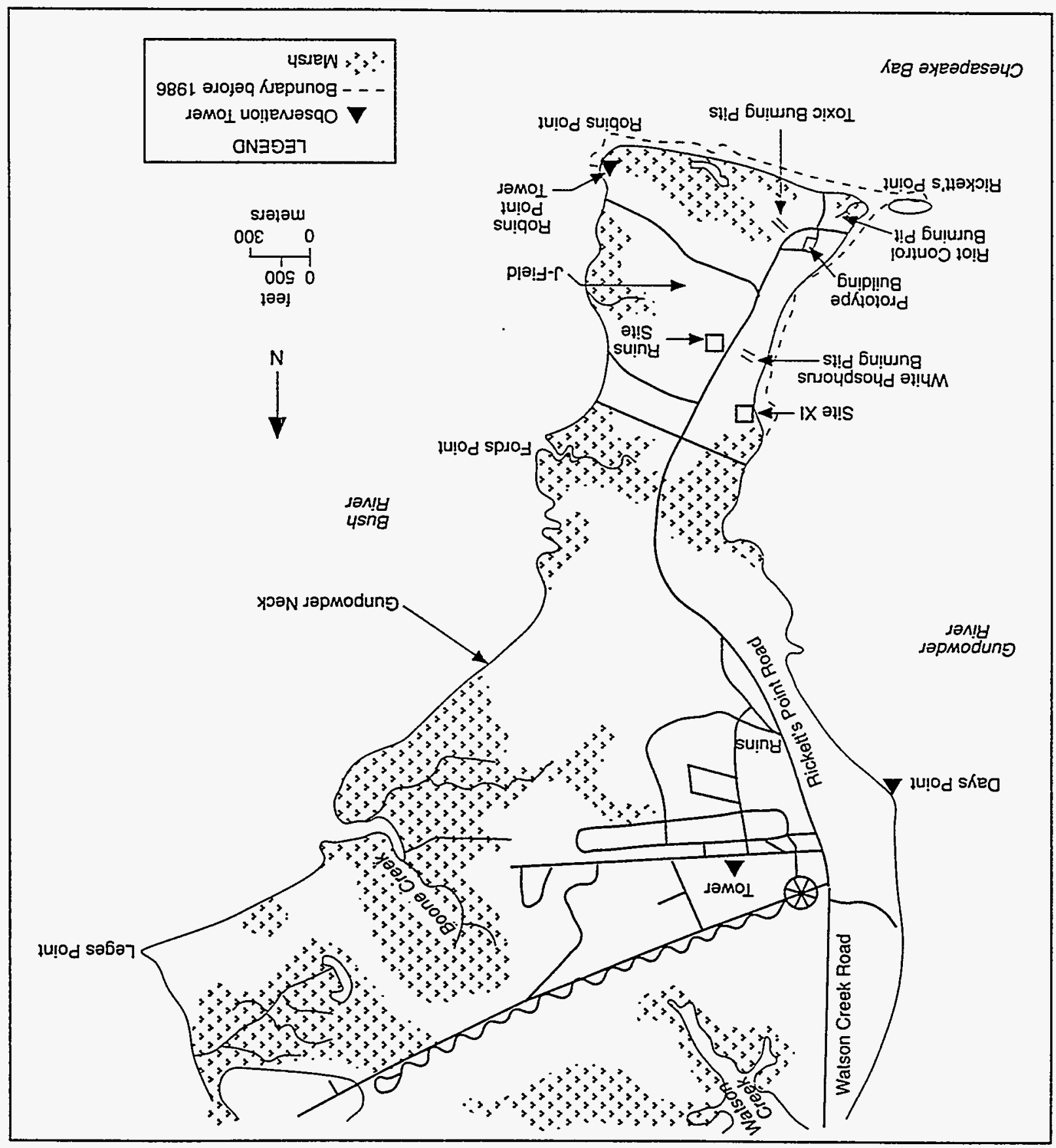




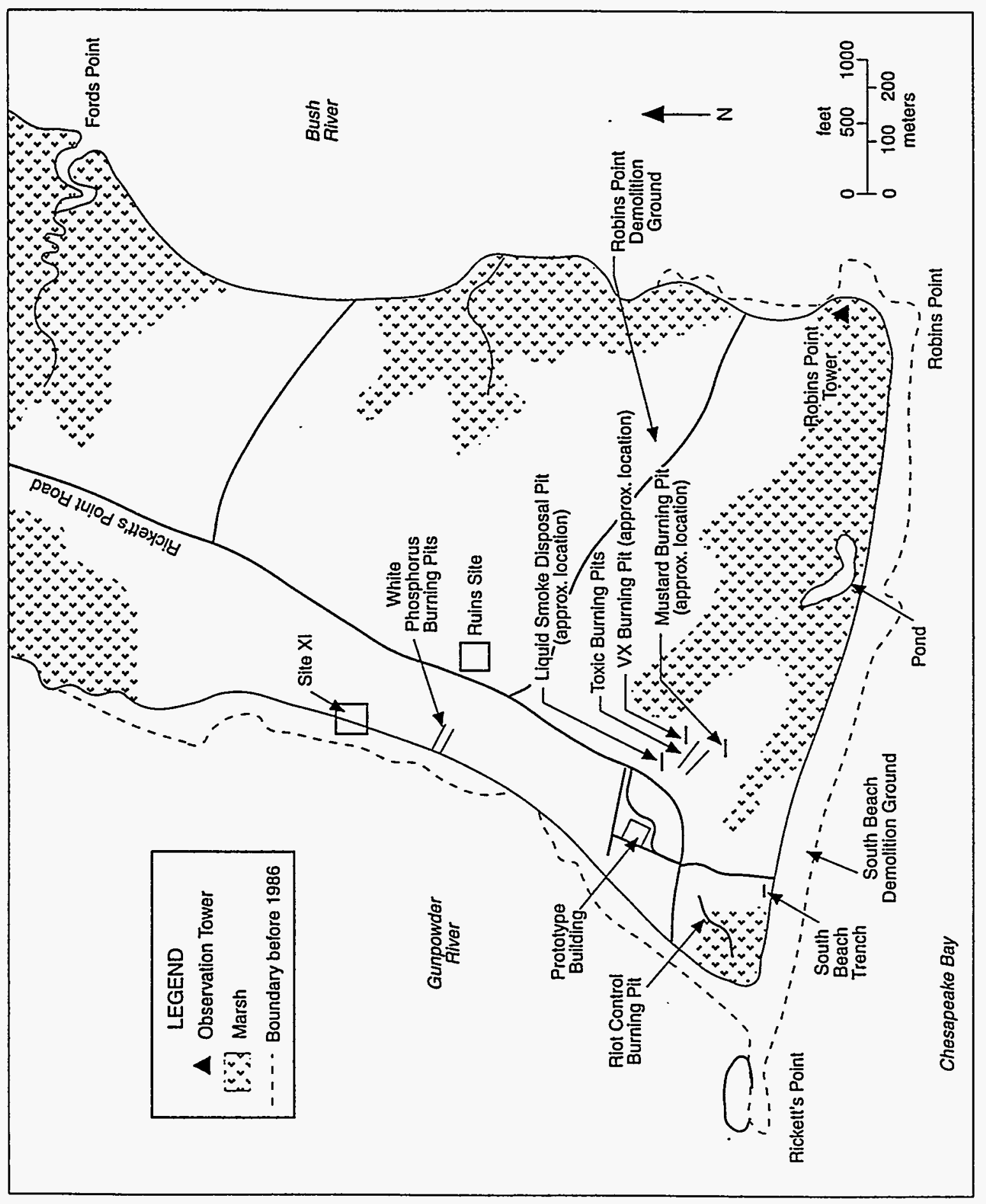

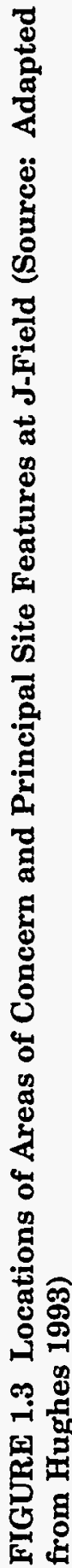


- South Beach Trench (SBT) AOC

- South Beach Demolition Ground (SBDG) AOC

- Prototype Building (PB) AOC

Although most of the AOCs are no longer used for OB/OD, a portion of the RPDG is currently active and is operating with interim status under RCRA. A RCRA Part B permit application was submitted in November 1988. An amended permit application is being prepared to update the November 1988 submittal. An open burning pan located $50 \mathrm{~m}$ west of the PB and an open detonation area at the WPP AOC are also being used for emergency disposal operations.

\subsection{SITE HISTORY}

The extent of activities at J-Field before World War II is unknown; however, a terrain map from the 1920s-1930s era indicates that some areas of J-Field were cleared at that time. These cleared areas may have been used for test activities (Nemeth 1989; U.S. Army Corps of Engineers [COE] 1923). During World War II, J-Field was used to test high explosives (HE) and chemical munitions. In addition, chemical agents, chemical wastes, and $\mathrm{HE}$ were burned or detonated in open pits or buried under several feet of soil. The depths of the pits were maintained by pushing burned soil and ash out toward the nearby marshes. In the case of the TBP AOC, this procedure moved the edge of the adjacent marsh eastward more than $100 \mathrm{ft}$ (Sonntag 1991). Also during World War II, steel-reinforced structures (such as bunkers, buildings, and slab walls) were built at J-Field to use as targets for conventional munitions.

Available information indicates that chemicals disposed of at J-Field have included nerve agents (such as VX), blister agents, riot control agents, white phosphorus, chlorinated solvents, and drummed chemical wastes generated by research laboratories, process laboratories, pilot plants, and machine and maintenance shops. Between 1946 and 1971, limited testing of lethal chemical agents continued at J-Field (Nemeth 1989). Open-air testing of lethal chemical agents stopped in 1969 (Nemeth 1989). Disposal activities at various J-Field locations are summarized in Table 1.1.

Procedures for open burning in J-Field pits involved placing 3-4 $\mathrm{ft}$ of wood dunnage in a pit, placing the materials to be burned on top of the dunnage, adding fuel oil, and igniting it. Scrap metal items were removed and reburned in the same manner in a reburn pit. Large metal items were recovered and disposed of as scrap.

Decontamination procedures included the use of a chlorinating agent known as "decontaminating agent, noncorrosive" (DANC). DANC is an organic $N$-chloroamide compound in solution with 1,1,2,2-tetrachloroethane (TCLEA) that was used to decontaminate 
TABLE 1.1 Summary of Disposal Activities at J-Field

\begin{tabular}{|c|c|c|}
\hline Site Name & Period of Use & Activity \\
\hline $\begin{array}{l}\text { Toxic Burning Pits } \\
\text { (originally } 5 \\
\text { separate pits; only } \\
2 \text { remain) }\end{array}$ & $1940-1980$ & $\begin{array}{l}\text { OB/OD of HE in southeastern portion. } \\
\text { Disposal of HE-filled munitions, nerve } \\
\text { agents, mustard, liquid smoke, } \\
\text { chlorinated solvents, and radioactive } \\
\text { chemicals. }\end{array}$ \\
\hline $\begin{array}{l}\text { White Phosphorus } \\
\text { Burning Pits }\end{array}$ & $\begin{array}{l}\text { Late } 1940 \text { s-1980; } \\
\text { occasional emergency disposal } \\
\text { of white phosphorus }\end{array}$ & $\begin{array}{l}\mathrm{OB} / \mathrm{OD} \text { of white phosphorus, } \mathrm{PWP}, \\
\text { other chemicals. Potential for disposal } \\
\text { of } \mathrm{CN}^{\mathrm{b}} \text { and trichloroethylene. }\end{array}$ \\
\hline $\begin{array}{l}\text { Riot Control } \\
\text { Burning Pit Area }\end{array}$ & $\begin{array}{l}\text { Late } 1940 \text { s to early } 1970 \text { s; } \\
\text { riot control agent disposal, } \\
1960 \text { s to early } 1970 \text { s }\end{array}$ & $\begin{array}{l}\text { OB of chemicals, chemical-filled } \\
\text { munitions, riot control agents (CS, } \\
\text { CN). }\end{array}$ \\
\hline $\begin{array}{l}\text { Robins Point } \\
\text { Demolition Ground }\end{array}$ & Late 1970 s-present & $\begin{array}{l}\text { OD of explosive materials, sensitive } \\
\text { and unstable chemicals. }\end{array}$ \\
\hline $\begin{array}{l}\text { South Beach } \\
\text { Demolition Ground }\end{array}$ & Late $1950 \mathrm{~s}-1970 \mathrm{~s}$ & $\mathrm{OD}$ of $\mathrm{HE}$. \\
\hline $\begin{array}{l}\text { Prototype Building } \\
\text { Area }\end{array}$ & During World War II & $\begin{array}{l}\text { Stored wastes and HE munitions. } \\
\text { Possible storage of solid wastes in } \\
\text { building or nearby. Building used to } \\
\text { test bombing effects. Periodically used } \\
\text { for storage since World War II. }\end{array}$ \\
\hline $\begin{array}{l}\text { Robins Point Tower } \\
\text { Site }\end{array}$ & Late $1950 \mathrm{~s}-1960 \mathrm{~s}$ & $\begin{array}{l}\text { Potential test burn of radioactively } \\
\text { contaminated wood. }\end{array}$ \\
\hline $\begin{array}{l}\text { South Beach } \\
\text { Trench }\end{array}$ & Late 1950s & Unknown. \\
\hline
\end{tabular}

a Plasticized white phosphorus.

b Chloroacetophenone.

c o-Chlorobenzylidene malononitrile.

Sources: Adapted from Nemeth (1989); EPA and U.S. Department of the Army (1990). 
mustard, Lewisite, and VX. It typically contained 90-95\% (by weight) TCLEA. If recovered scrap materials were decontaminated with DANC in the pit before being removed, the oxidizing agent would degrade. The most significant impact from this procedure would have been the introduction of TCLEA into the environment. Available information indicates that the use of DANC at J-Field was widespread and common (Nemeth 1989).

Disposal of radioactive waste is known to have occurred at J-Field. The TBP area was used for disposal of small amounts of radioactively labeled chemicals. In addition, test burns of contaminated wood wastes, including wood contaminated with radium and strontium-90, may have been conducted at the RPTS (Nemeth 1989).

J-Field has had only limited use since 1980. However, the Robins Point Demolition Ground and the WPP AOCs are still occasionally used for the destruction of explosivesrelated materials (Nemeth 1989).

\subsection{PURPOSE}

The purpose of a feasibility study (FS) is to gather sufficient information to support an informed decision about which remedial actions are most appropriate to address contamination at a site being evaluated pursuant to CERCLA. Information about the nature and extent of contamination is gathered and analyzed during an RI and then is used during the FS to determine suitable remedial action alternatives for the site.

The purpose of a focused feasibility study (FFS) is to identify and evaluate the remedial action alternatives that can be implemented to address the sources of contaminants of concern associated with a specific component of a CERCLA site. This FFS addresses contamination in the vicinity of the TBP AOC within J-Field (Figure 1.1). The final remedial alternative that is recommended will consist of one or more technologies that meet the criteria established by the EPA for the remediation of CERCLA sites. The preferred alternative will be an alternative that best protects human health and the environment and is cost effective (i.e., the lowest-cost alternative that is technically feasible and is considered protective). The decisions about alternatives will be based on the procedures developed by the EPA in Guidance for Conducting Remedial Investigations and Feasibility Studies under CERCLA, Interim Final (EPA 1988).

This FFS work plan outlines the tasks that will be performed to evaluate and select remedial technologies in conformance with the requirements of the National Contingency Plan (NCP), CERCLA, and the Superfund Amendments and Reauthorization Act (SARA). The stages in this evaluation process will include (1) developing remedial action objectives and response actions, (2) identifying alternative remedial action technologies, (3) screening remedial alternatives to provide a comparison with minimum acceptance criteria, and (4) performing detailed evaluation of remedial alternatives (including comparison of those alternatives) and selecting the preferred alternative. 


\subsection{REPORT ORGANIZATION}

Section 1 of this FFS work plan presents background information, summarizes the site history, and discusses the purpose of the FFS. Section 2 summarizes the site background, environmental setting, and previous and ongoing investigations. Also included is an overview of available information about the nature and extent of contamination at the TBP AOC, the types of waste present, and the potential pathways of contaminant migration.

- The environmental setting includes site topography, soils and geology, surface water, groundwater, climate, ecology, land use, and demography.

Section 3 describes the activities for each of the eight main FFS tasks. A draft outline of the FFS report is presented in Section 4, along with a summary of the contents of each report section. Section 4 also details the information to be provided to the Directorate of Safety, Health, and Environment (DSHE) on a monthly basis during the course of the project. All references cited in this report are listed in Section 5, and a list of preparers is provided in Section 6. 


$$
1-10
$$




\section{ENVIRONMENTAL CONDITIONS}

\subsection{ENVIRONMENTAL SETTING}

\subsubsection{Surface Features}

J-Field is nearly flat, with a maximum relief of about $10 \mathrm{ft}$. The ground surface slopes gently toward marshy areas or toward Chesapeake Bay and on-site surface water. In some places, wave erosion has formed short, steep cliffs (2-10 ft high) along the shore (Hughes 1993).

Surface water occurs in demolition craters, in marsh areas, and in a few open ponds within the marshes. Between December and May water collects in wooded areas where drainage is poor because the low-permeability soils slow the rate of infiltration. Figure 2.1 shows the overall topography of the site.

\subsubsection{Climate}

The climate in the area of APG is temperate and moderately humid and is moderated by the presence of Chesapeake Bay. The average annual precipitation of 45 in. is distributed relatively uniformly during the year. The average annual temperature is about $54^{\circ} \mathrm{F}$ (Nemeth 1989; Hughes 1993).

\subsubsection{Geology and Soils}

The stratigraphy of J-Field consists of Quaternary (Talbot) sediments underlain by Cretaceous (Potomac Group) sediments. The Quaternary sediments constitute a fluvial, estuarine, and marginal marine unit of sand, gravel, and silty clay. The Cretaceous sediments are a sand and clay unit of fluvial origin.

The Quaternary sediments can be divided into three units. The surface unit consists of interbedded sand and clay about 30-40 ft thick; the middle unit is silty, sandy clay and organic matter about 36-107 ft thick; and the base unit is gravelly sand and clay about 13-50 ft thick. The Cretaceous sediments consist of interbedded layers of fine-grained sand and massive clay. The top of this layer is at a depth of 110-160 ft. Metamorphic bedrock underlies the sediments at depths ranging from 200 to $900 \mathrm{ft}$.

\subsubsection{Surface Water}

The southern and eastern shores of J-Field are covered by an extensive marsh system (Figure 2.2). The marshes may be flooded during storms and very high tides but are 


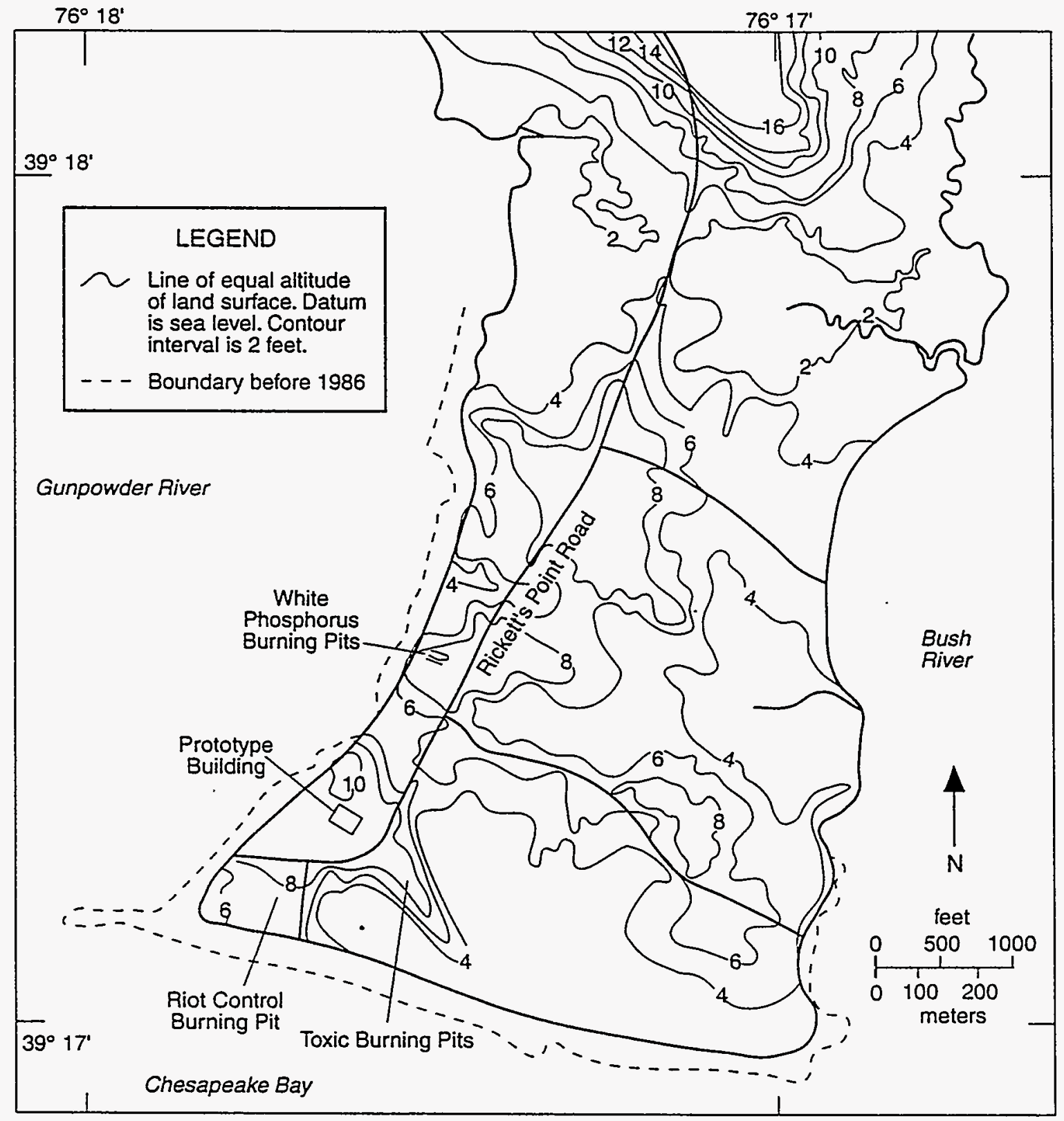

FIGURE 2.1 Topography of the J-Field Area (Source: Adapted from Hughes 1993) 


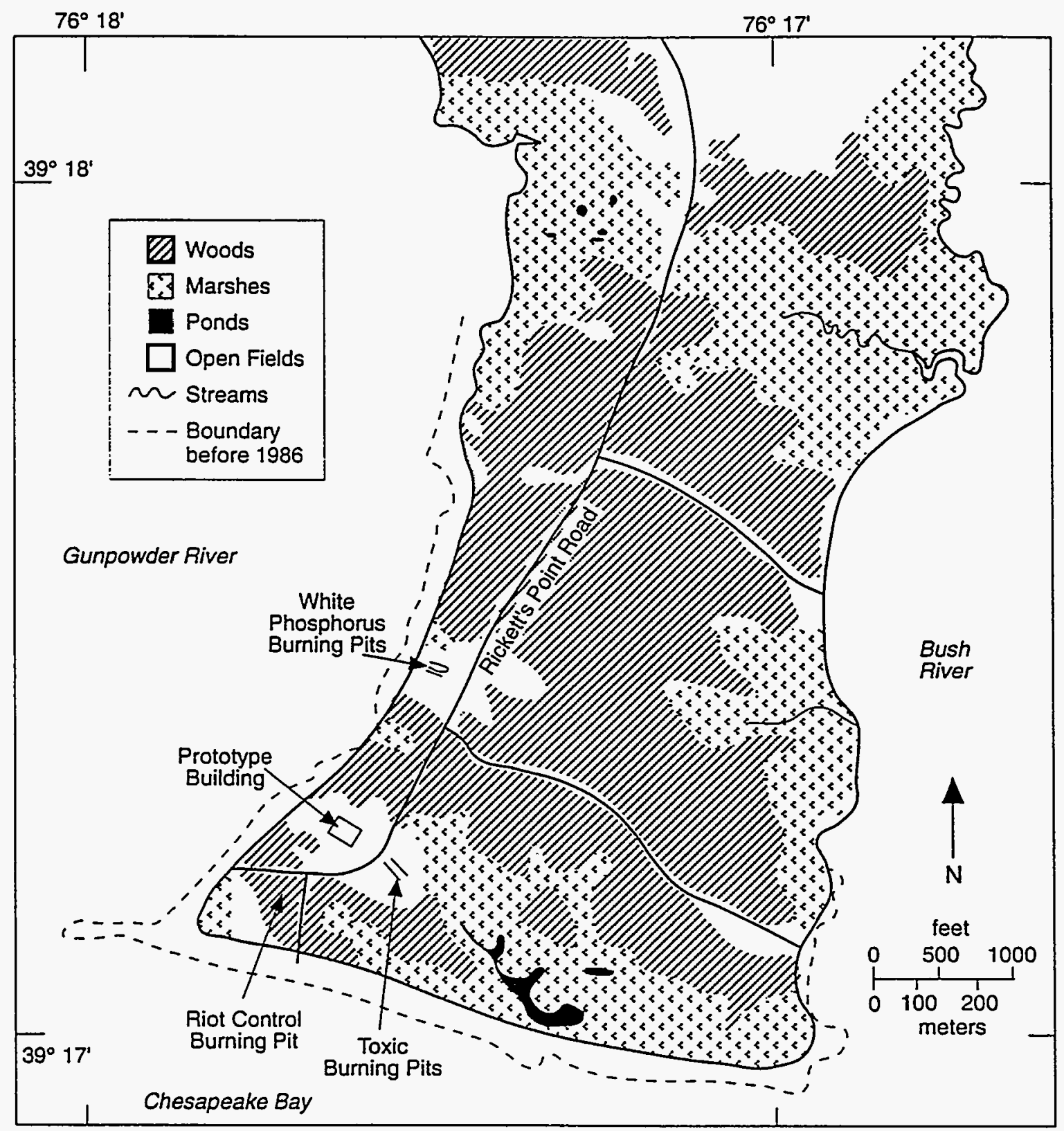

FIGURE 2.2 Locations of Woods, Marshes, Ponds, Open Fields, and Streams at J-Field (Source: Adapted from Hughes 1993) 
not affected by normal tides of 1-2 ft. The water level in the marshes is generally about $2 \mathrm{ft}$ above high tide in Chesapeake Bay. The disposal pits at J-Field originally drained into these marshes or into the Gunpowder and Bush rivers. During the 1970s, drainage from the disposal pits was blocked. Currently, surface water can be 1-2 $\mathrm{ft}$ deep in the TBP and the WPP during the wet season, generally March to June (Hughes 1993). Several ponds and streams are located within the marshy areas of J-Field (Figure 2.2). Most of the ponds are interconnected. The largest pond, which is about $5 \mathrm{ft}$ deep, is southeast of the TBP. Two streams on the eastern side of J-Field are the only on-site streams and do not carry much runoff except during storms.

\subsubsection{Groundwater}

Four major hydrologic units have been identified beneath J-Field - the surficial aquifer (in the overlying Talbot layer), the leaky confining unit (in the middle layer), the confined aquifer (in the bottom Talbot unit), and the Potomac Group aquifer. Groundwater flow in these units is described below on the basis of current knowledge of the aquifers. Groundwater is currently being modeled in these units. The model results are not yet available, but will be presented in the RI report with other results of the RI field investigation.

\subsubsection{Surficial Aquifer}

The surficial aquifer consists of interbedded sand and clay and corresponds to the surface unit of the Quaternary (Talbot) sediment; it ranges from 25 to $40 \mathrm{ft}$ thick, with elevations following the surface topography. The steepest hydraulic gradients were found near the TBP and WPP. Because the closest pumping of this aquifer is about $4 \mathrm{mi}$ to the west, the major influences on the flow system are recharge, evapotranspiration, and tidal fluctuations. Recharge is mainly through rainfall, and the system discharges into the marshes and Chesapeake Bay. Some recharge from Chesapeake Bay may occur during droughts (Hughes 1993). Figure 2.3 shows the direction of groundwater flow in the surficial aquifer.

A general downward gradient that occurs between the water table and the leaky confining layer indicates that the leaky confining unit is recharged primarily by the surficial aquifer. During the summer, the direction of vertical flow is reversed at some locations. Groundwater under the marsh and the rivers, which are discharge areas, probably leaks upward from the leaky confining aquifer into the surficial aquifer.

\subsubsection{Leaky Confining Unit}

The leaky confining unit consists of silty, sandy clay and organic matter and corresponds to the middle unit of the Quaternary (Talbot) sediments. Vertical leakage from 


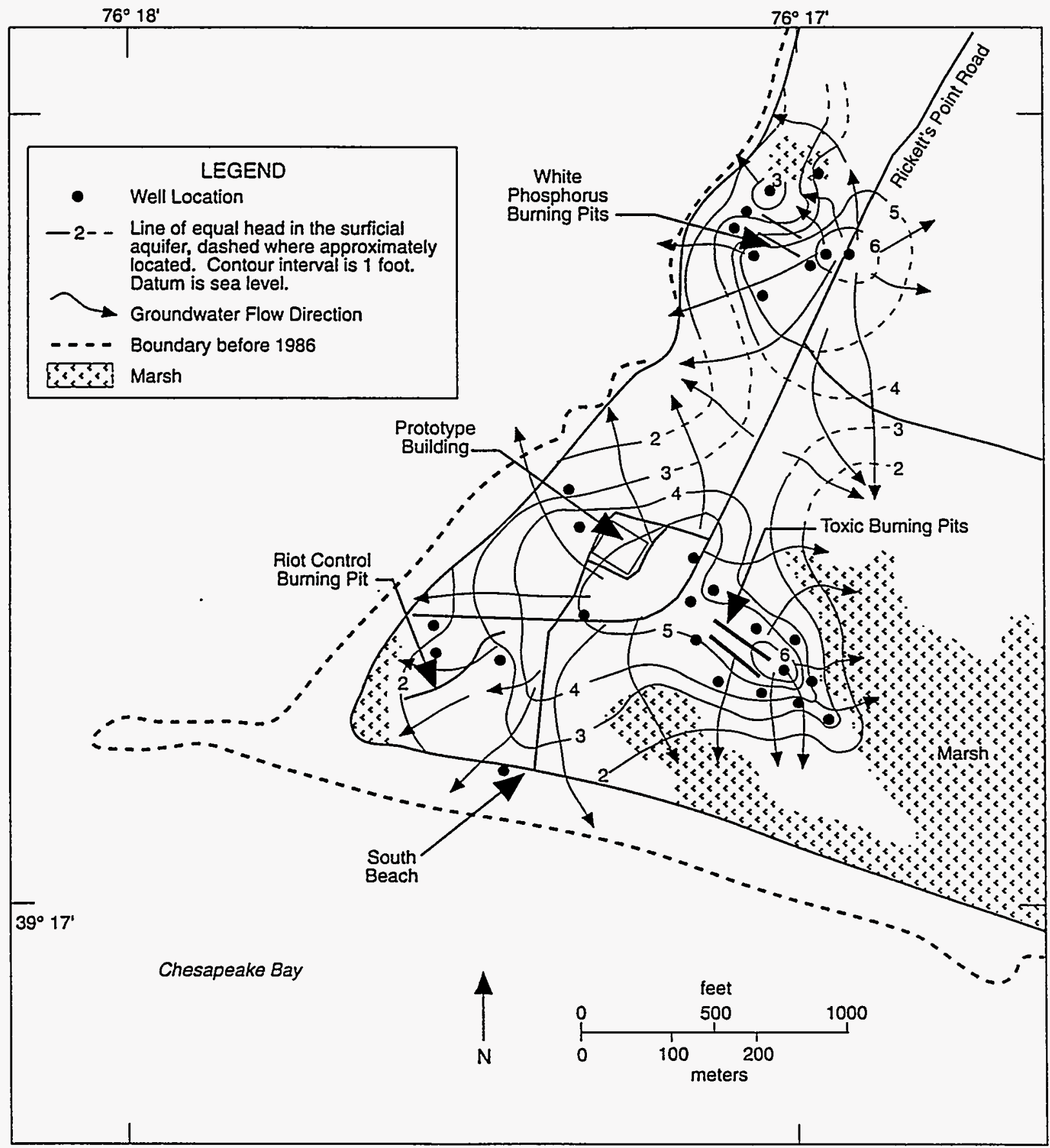

FIGURE 2.3 Groundwater Flow in the Surficial Aquifer, November 1989 (Source: Adapted from Hughes 1993) 
the leaky confining unit to the underlying confined aquifer occurs at all sites beneath J-Field but is probably quite limited offshore. The direction of vertical flow may be reversed in some offshore areas (Hughes 1993).

Lateral flow in the leaky confining unit is generally the same as that of the surficial aquifer. In the western part of the site, the unit is $40 \mathrm{ft}$ thick, with a surface elevation $25 \mathrm{ft}$ below mean sea level (MSL). In the eastern portion of the site, the unit is $107 \mathrm{ft}$ thick and has a surface elevation of $35 \mathrm{ft}$ below MSL. Hydraulic conductivities range from less than 0.01 to $0.20 \mathrm{ft} / \mathrm{d}$, with a median value of $0.05 \mathrm{ft} / \mathrm{d}$ (Hughes 1993).

\subsubsection{Confined Aquifer}

The confined aquifer consists of gravelly sand and clay and corresponds to the base unit of the Quaternary (Talbot) sediments. In the western part of J-Field, the top of the confined aquifer is $60 \mathrm{ft}$ below MSL, and the unit is $50 \mathrm{ft}$ thick. In the southeast, this aquifer dips to a surface elevation of $142 \mathrm{ft}$ below MSL and thins to $15 \mathrm{ft}$ thick. Lateral flow directions are similar to those in the water table; however, the hydraulic head and lateral gradients are very small. Groundwater flows away from the TBP toward the marshes and Chesapeake Bay, and wells show evidence of a tidal influence. Seasonal variations in the flow direction of the confined aquifer occur for short periods during the summer (Hughes 1993).

\subsubsection{Potomac Group Aquifer}

The Potomac Group aquifer consists of interbedded, fine-grained sand and massive clay. This aquifer corresponds to the Cretaceous (Potomac Group) sediments of fluvial origin. Surface elevations of the Potomac Group aquifer range from $105 \mathrm{ft}$ below MSL in the eastern part of J-Field to $157 \mathrm{ft}$ below MSL in the western part. The thickness of the aquifer is, in

general, uncertain but may be up to $800 \mathrm{ft}$. The sediments are underlain by metamorphic bedrock. Insufficient data are available to determine lateral or vertical flow directions or the effects of the seasons and tides on the Potomac Group aquifer (Hughes 1993).

\subsubsection{Ecology}

Gunpowder Neck Peninsula consists primarily of open fields (mowed and unmowed grass), bare ground, and second-growth woods (dominated by maple, oaks, and sweetgum). J-Field supports extensive areas of these second-growth woods and freshwater wetlands (dominated by reed canary grass). A large wetland at the southern end of J-Field (Figure 2.2) supports extensive areas of reed and includes a large area of open water. All wetlands at J-Field are separated from the Chesapeake Bay by beach ridges and thus are not directly influenced by tidal fluctuations except through changes in groundwater levels. A few areas of bare ground are located on the western and eastern sides of J-Field, particularly in the vicinity of disposal pits. Additional freshwater tidal and nontidal wetlands occur along the 
periphery of the Gunpowder Neck Peninsula, outside of J-Field. The peninsula is surrounded by freshwater tidal estuaries - Chesapeake Bay to the south, Gunpowder River to the west, and Bush River to the east.

Both the TBP and the WPP AOCs are in open areas cleared of natural vegetation. The area immediately around each pit consists of mowed grass with weeds typical of disturbed habitats and old fields. The TBP are west of a large wetland at the southern end of J-Field. Some of the burned material from these pits has, over time, been pushed into the wetland. The WPP are very close to the Gunpowder River. In 1986, a berm was constructed to prevent waste material from these pits from entering the river. Such material is now diverted into a wetland approximately $100 \mathrm{~m}$ north of the pits. The RCP has not been used since the early 1970s; therefore, it is presently overgrown with shrubs and reeds. It is likely that runoff from the pit enters an adjacent wetland and the Gunpowder River.

The biota at J-Field have not been surveyed in detail; however, common species are likely to include those typical of other areas of the APG. Mammals likely to be common at J-Field include the muskrat, raccoon, white-tailed deer, short-tailed shrew, and white-footed mouse. Common birds could include great blue heron and spotted sandpiper. Because of its status as a federal endangered species, the bald eagle (known to occur at J-Field) is of ecological and regulatory interest. Composition of the fish communities in the J-Field wetlands has not been determined. Common species in the surrounding estuary include alewife, American shad, Atlantic menhaden, channel catfish, and white perch.

\subsection{DESCRIPTION OF THE TBP AOC}

The TBP AOC is located on about 9 acres in the southern portion of J-Field (Figures 1.3 and 2.4). Disposal operations at the TBP area began in the 1940s and have continued until the present. The pits were used most extensively between the late 1940s and the 1960s. Items disposed of included chemical agents, bulk chemical wastes, drummed chemical wastes, HE (by OB/OD), nerve agents, incapacitating agents (also known as riot control agents), chlorinated solvents, and blister agents (Nemeth 1989).

Information from interviews, sampling, and magnetic surveys indicates that five disposal pits were used at the TBP area. The two existing (or main) burning pits (each covering about $4,500 \mathrm{ft}^{2}$ ) were the pits most actively used for the disposal of various chemical agents and explosives. Three other burning pits, now covered, were used to dispose of VX, dichlorodiethyl sulfide (mustard), and the primary components of liquid smoke - titanium tetrachloride (FM) and sulfur trioxide/chlorosulfonic acid (FS).

The VX pit and mustard pit are about 100 and $150 \mathrm{ft}$ long, respectively. The liquid smoke disposal pit is fairly small, covering an area of about $24 \mathrm{ft}^{2}$. Liquid smoke was probably disposed of by placing it on the ground and allowing it to vaporize into the atmosphere. HE munitions were also disposed of by detonation in an area along the southeastern edge of the TBP area (Nemeth 1989). 


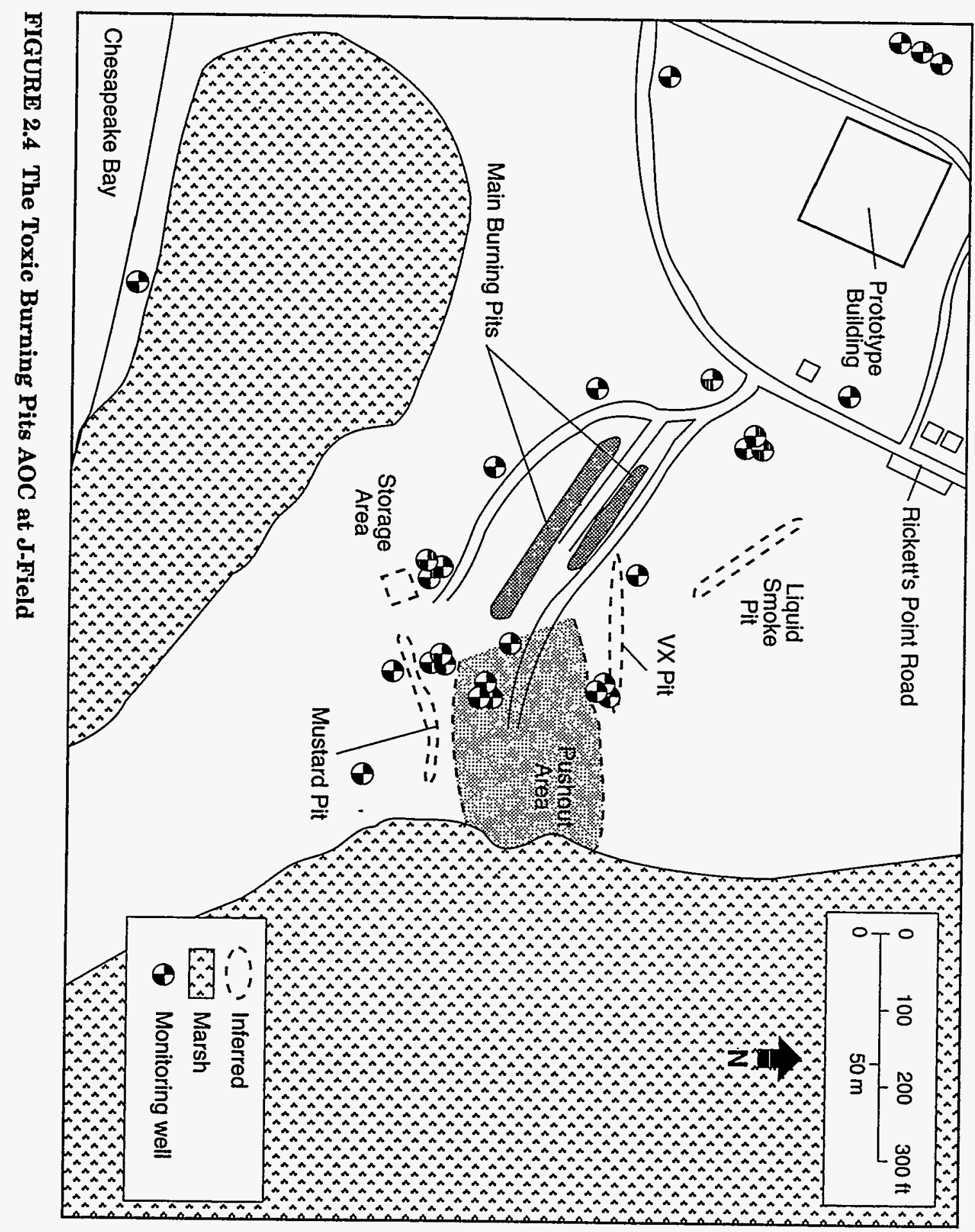


Storage and handling areas have been identified (in aerial photographs) at the upper end of both the VX burning pit and the mustard burning pit. In addition, a square pit, approximately $4 \mathrm{ft}$ by $4 \mathrm{ft}$ and $3 \mathrm{ft}$ deep has been identified at the current tree line south of the main burning pits. These storage and handling areas and the pit could be additional sources of contamination in the TBP AOC.

The TBP area is bounded to the northeast by marsh and to the south and southeast by woods and marsh (Nemeth 1989). Because the elevation of the ground surface is highest in the northwestern portion of the TBP area, surface water probably drains toward the southsoutheast into the marsh area. The direction of groundwater flow in the surficial aquifer is probably also toward the marsh. Soils are brownish-yellow silty fine sand at the surface, grading to bluish-gray silty fine sand below a depth of $14 \mathrm{ft}$ (Princeton Aqua Science 1984).

\subsection{PRELIMINARY EVALUATION OF THE TBP AOC}

Several investigations have been conducted at J-Field to characterize contamination from past operations, install monitoring wells, and characterize the estuarine sediments around the peninsula. Table 2.1 provides a chronological summary of these studies. An overview of the results of these studies as they pertain to the TBP AOC is presented in the following sections.

\subsubsection{Types of Waste Present}

The TBP were used to dispose of HE-filled munitions, nerve agents, mustard agents, chemical warfare agents (CWAs), decontaminating agents, liquid smoke, chlorinated solvents, and radioactive chemicals. In addition, fuel was used to ignite materials placed in the pits.

\subsubsection{Types of Contaminants Present}

A hydrological assessment of J-Field was carried out in two phases by the USGS. Phase I was conducted from 1987 to 1992 to select locations for establishing monitoring wells at the TBP and WPP areas. It was assumed that the pits and the open burning grounds around them were the primary sources of contamination in the area. The goal of Phase II, conducted in 1992, was to determine the extent of contamination in the area of the TBP, sample the RCP area, and determine if contaminated groundwater was moving into Chesapeake Bay (Hughes 1993). The following subsections discuss the findings relative to the nature and extent of contamination in the TBP area.

\subsubsection{Soil Gas}

During Phase I of the hydrological assessment, the USGS sampled 37 locations around the TBP for soil-gas concentrations of trichloroethylene (TRCLE), tetrachloroethylene 
TABLE 2.1 Summary of Previous Investigations at J-Field

\begin{tabular}{|c|c|c|c|}
\hline Field Investigation & Investigator $^{a}$ & Date & Objective/Activity \\
\hline $\begin{array}{l}\text { Environmental } \\
\text { Contamination Survey }\end{array}$ & USATHAMA & $1977-1978$ & $\begin{array}{l}\text { Conducted to determine if contamination from past } \\
\text { operations was migrating off-post. Eleven monitoring wells } \\
\text { (TH1-11) were installed in the surficial aquifer }-10 \text { near the } \\
\text { TBP and WPP and } 1 \text { near the Robins Point Tower. Ground- } \\
\text { water samples were collected and analyzed. }\end{array}$ \\
\hline Munitions Disposal Study & $\begin{array}{l}\text { Princeton Aqua } \\
\text { Science }\end{array}$ & 1983 & $\begin{array}{l}\text { Installed nine monitoring wells (P1-9) in the surficial } \\
\text { aquifer - five near the TBP and four near the WPP. } \\
\text { Composite soil samples were collected during drilling of wells. } \\
\text { Soil samples were also collected from the pits in the TBP and } \\
\text { WPP areas. }\end{array}$ \\
\hline $\begin{array}{l}\text { RCRA Facility } \\
\text { Investigation }\end{array}$ & USAEHA & 1986 & $\begin{array}{l}\text { Sampled groundwater from TH and P series wells. Soil } \\
\text { samples also collected in and around the pits in the TBP, } \\
\text { WPP, and RCP areas and near the Prototype Building. A } \\
\text { field radiation survey was also performed. }\end{array}$ \\
\hline $\begin{array}{l}\text { Hydrological Assessment, } \\
\text { Phase I }\end{array}$ & USGS & $1987-1992$ & $\begin{array}{l}\text { Drilled exploratory boreholes, collected soil samples, and ran } \\
\text { geophysical logs. Installed } 12 \text { well clusters (JF1-12), each } \\
\text { consisting of } 3 \text { wells screened in the upper portions of the } \\
\text { confined aquifer, the confining unit, and surficial aquifer. } \\
\text { Wells were sampled on a monthly (1987) and quarterly } \\
\text { basis (1989-1992); water-level measurements also taken. } \\
\text { Conducted slug tests. Currently using MODFLOW model to } \\
\text { simulate contaminant pathways in groundwater. A total of } \\
21 \text { surface samples also collected from Gunpowder River and } \\
\text { Chesapeake Bay. Soil and soil-gas samples collected in TBP } \\
\text { and WPP areas. }\end{array}$ \\
\hline
\end{tabular}


TABLE 2.1 (Cont.)

\begin{tabular}{|c|c|c|c|}
\hline Field Investigation & Investigator & Date & Objective/Activity \\
\hline $\begin{array}{l}\text { Characterization and } \\
\text { Interim Remediation }\end{array}$ & $\begin{array}{l}\text { Roy F. Weston, } \\
\text { Inc. }\end{array}$ & 1992 & $\begin{array}{l}\text { Activities included topographic survey of J-Field area; survey } \\
\text { of UXO } \mathrm{b}^{\mathrm{b}} \text { in each burning pit and along shoreline of WPP and } \\
\text { RCP; construction of access roads; placement of riprap and } \\
\text { gabion structures along WPP and RCP shoreline; removal } \\
\text { and staging of surface material and debris from burning pit } \\
\text { areas; sampling and staging drums from the Prototype } \\
\text { Building; sampling and analysis of soil from the pits and } \\
\text { pushout areas; installation of flood control berms in the pit } \\
\text { areas, where needed; and collection of surface and subsurface } \\
\text { soil samples. }\end{array}$ \\
\hline $\begin{array}{l}\text { Hydrological Assessment- } \\
\text { Phase II }\end{array}$ & USGS & 1992 & $\begin{array}{l}\text { Continued sampling of groundwater, measuring water levels } \\
\text { in all monitoring wells, and slug testing. Four new wells } \\
\text { installed. Collected surface water samples from marsh areas } \\
\text { and estuaries surrounding J-Field, based on thermal imagery } \\
\text { studies conducted by the USGS. }\end{array}$ \\
\hline Sediment Sampling Study & EPA & 1992 & $\begin{array}{l}\text { Conducted a study to characterize the estuarine sediments } \\
\text { around the Gunpowder Neck Peninsula. }\end{array}$ \\
\hline
\end{tabular}

a Abbreviations: USATHAMA = U.S. Army Toxic and Hazardous Materials Agency; USAEHA = U.S. Army Environmental Hygiene Agency; USGS = U.S. Geological Survey; and EPA = U.S. Environmental Protection Agency.

b UXO = unexploded ordnance. 
(TCLEE), alkanes, combined hydrocarbons, and simple aromatics. The relative contours for all contaminants except the alkanes show a broad band of contamination that extends across the eastern end of the pits from the marsh on the north to the marsh on the south (Figure 2.5). The alkanes appear to be limited to the area south of the TBP, and the data suggest a plume of contamination moving into the marsh at the southern edge (Figure 2.6) (Hughes 1993).

Additional soil-gas samples were collected during Phase II from wooded and marshy areas north and south of the TBP and from 15 locations along Chesapeake Bay. Samples were analyzed for combined dichloroethylenes (DCEs) and trichloroethanes (TCEs), combined TRCLEs and TCLEEs, phthalates, and heavy aromatic hydrocarbons (Hughes 1993).

Relative values and contours for concentrations of combined DCE and TCE and of combined TRCLE and TCLEE show a similar distribution, with elevated contamination to the southeast of the TBP. Figure 2.7 shows contours for combined TRCLE and TCLEE. The DCE plus TCE contamination south of the pits is somewhat more extensive, with elevated values extending to the shore of Chesapeake Bay. The concentration contours, when combined with contours from Phase I analyses, suggest that plumes of contaminated groundwater are moving downgradient under the marshes both on the northern and southern sides of the TBP. This hypothesis is supported by the relative contours for heavy aromatics (Figure 2.8), which show locations with more extensive contamination, including along the shore. The data also suggest that contaminated groundwater may be moving beneath, and possibly discharging into, the bay, or that contaminated surface water from the marshes may be moving into shore sediments (Hughes 1993).

\subsubsection{Soil}

In 1983, soil samples were collected during the installation of monitoring wells at the TBP. Four composite samples were collected at depth intervals of $5 \mathrm{ft}$. The samples were analyzed for metals, cyanide, phenols, total phosphorus, volatile organic compounds (VOCs), pesticides, polychlorinated biphenyls (PCBs), and herbicides. Some of the results are listed in Table 2.2. The data showed elevated concentrations of lead, zinc, nitrate, and petroleum hydrocarbons in each of the samples. It should be noted that the background samples also contained somewhat elevated concentrations of petroleum hydrocarbons.

During the 1986 RFA (Nemeth 1989), surface soil samples were collected from 20 locations in the TBP and the debris pushout area (Figure 2.9). All of the samples were analyzed for metals, extractable metals, and explosives-related compounds. The results, as summarized in Table 2.3, show that the surface soil in and around the TBP contain elevated levels of metals, especially lead (up to $2.6 \%$ in the pushout area [location 12]); mercury (up to $10.8 \mathrm{mg} / \mathrm{kg}$ in one of the pits [location 8]); and cadmium (16.6 mg/kg at location 20). Samples from locations 7 and 12 exceeded the RCRA extraction procedure (EP) limit of $5.0 \mathrm{mg} / \mathrm{L}$ for lead (40 CFR 261). 


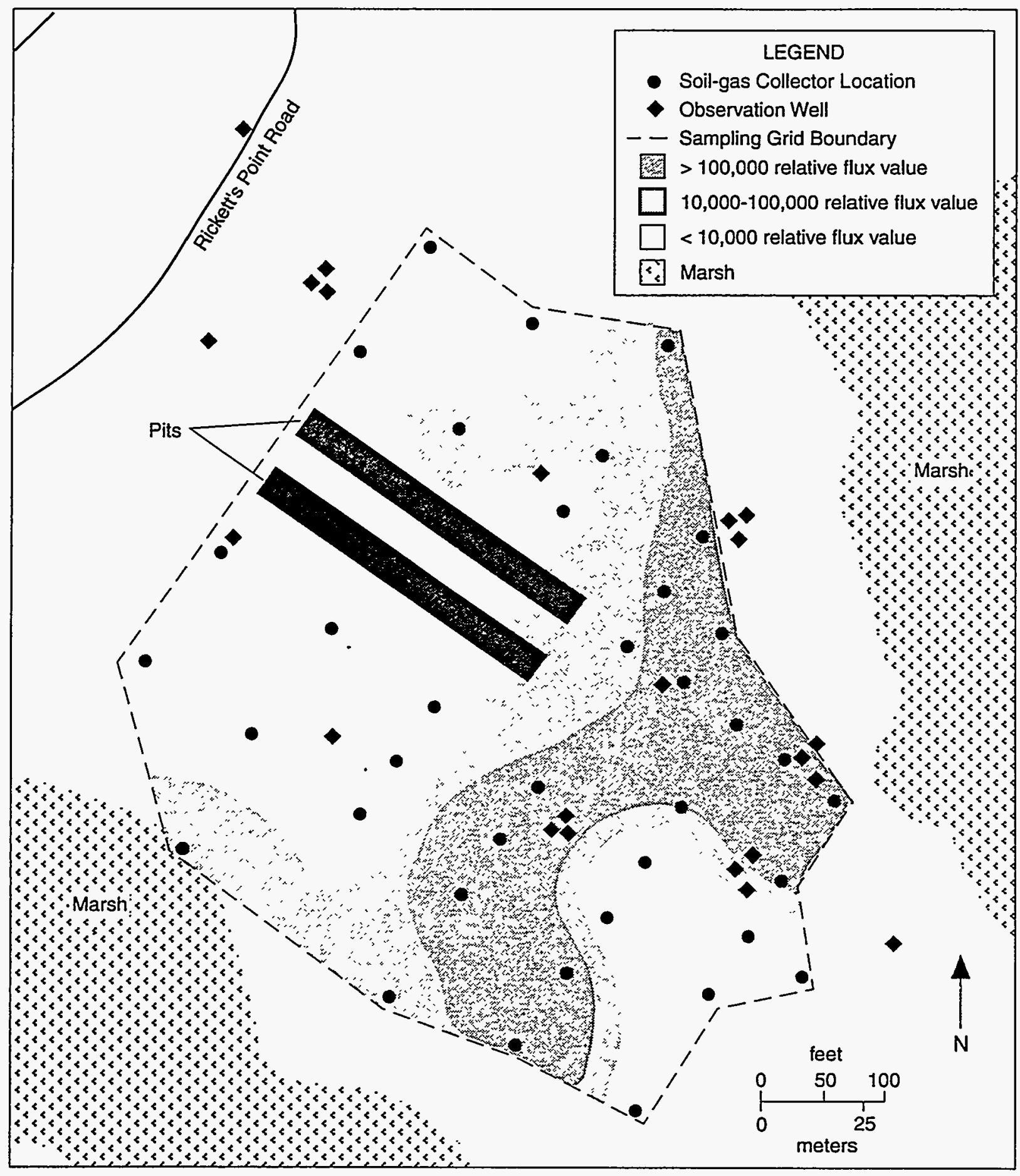

FIGURE 2.5 Relative Contours for all Soil-Gas Parameters (except alkanes) at the Toxic Burning Pits Area (Source: Adapted from Hughes 1993) 


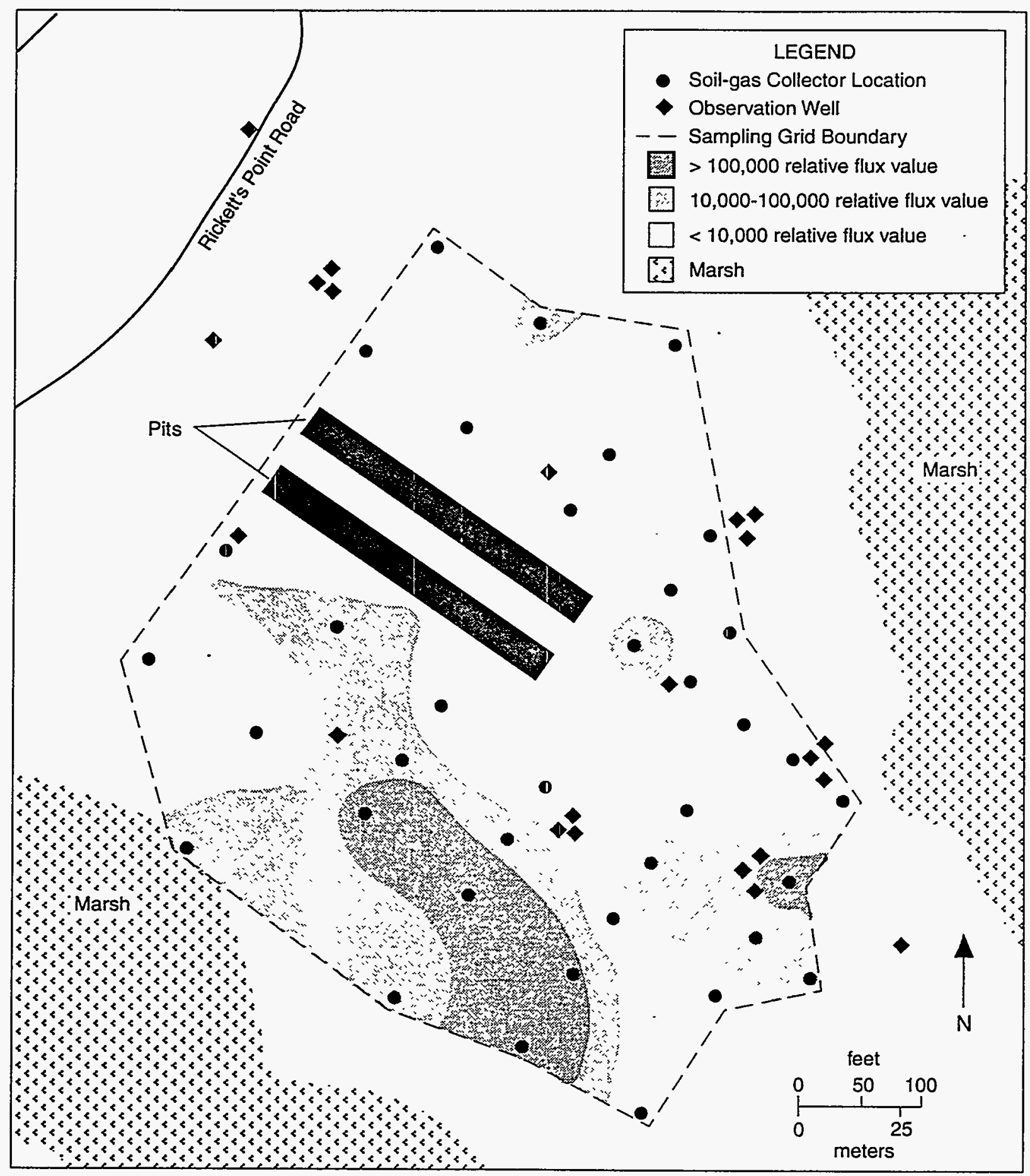

FIGURE 2.6 Relative Contours for Alkanes in Soil Gas from the Toxic Burning Pits Area (Source: Adapted from Hughes 1993) 


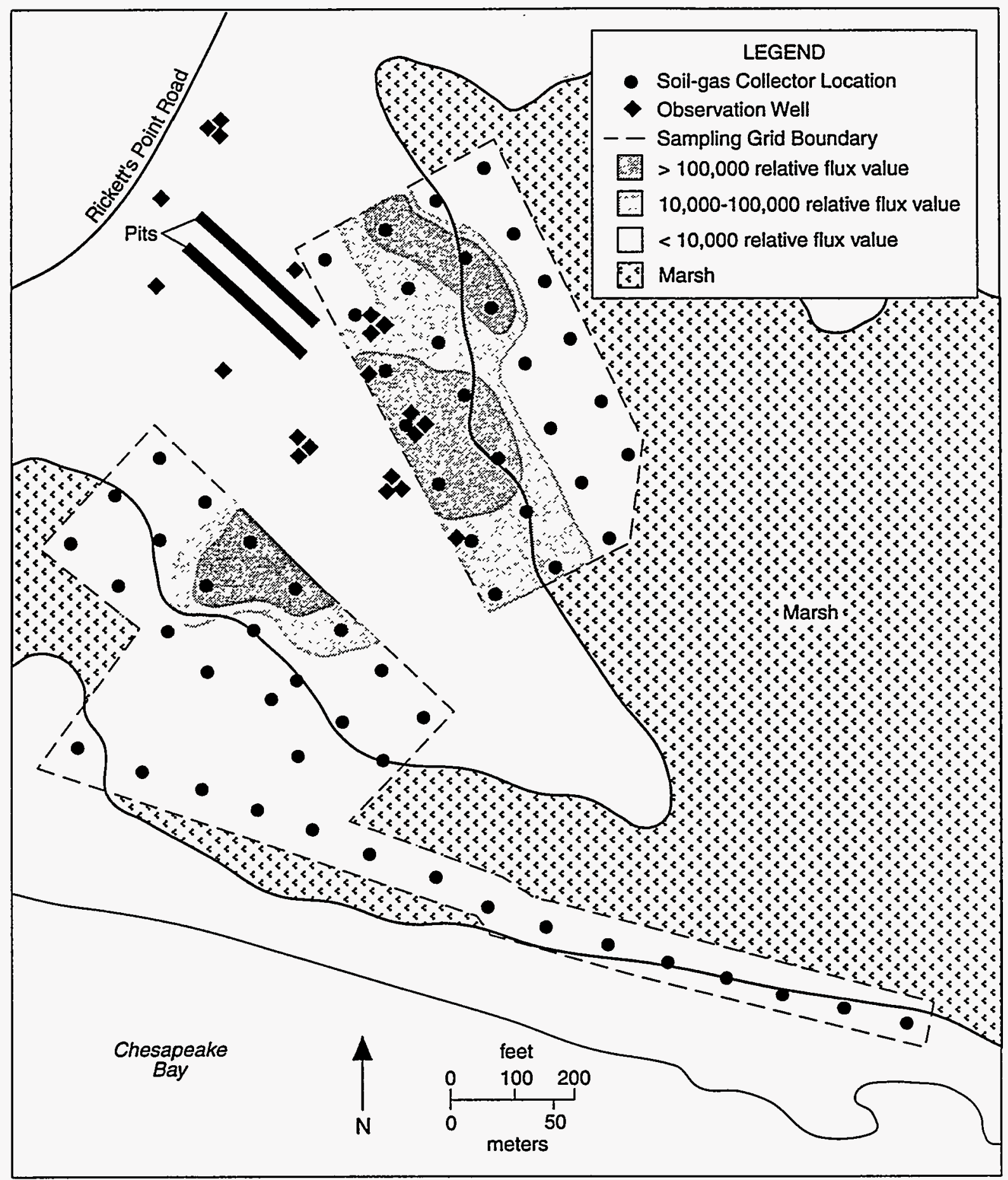

FIGURE 2.7 Relative Contours for Combined TRCLE and TCLEE at the Toxic Burning Pits Area (Source: Adapted from Hughes 1993) 


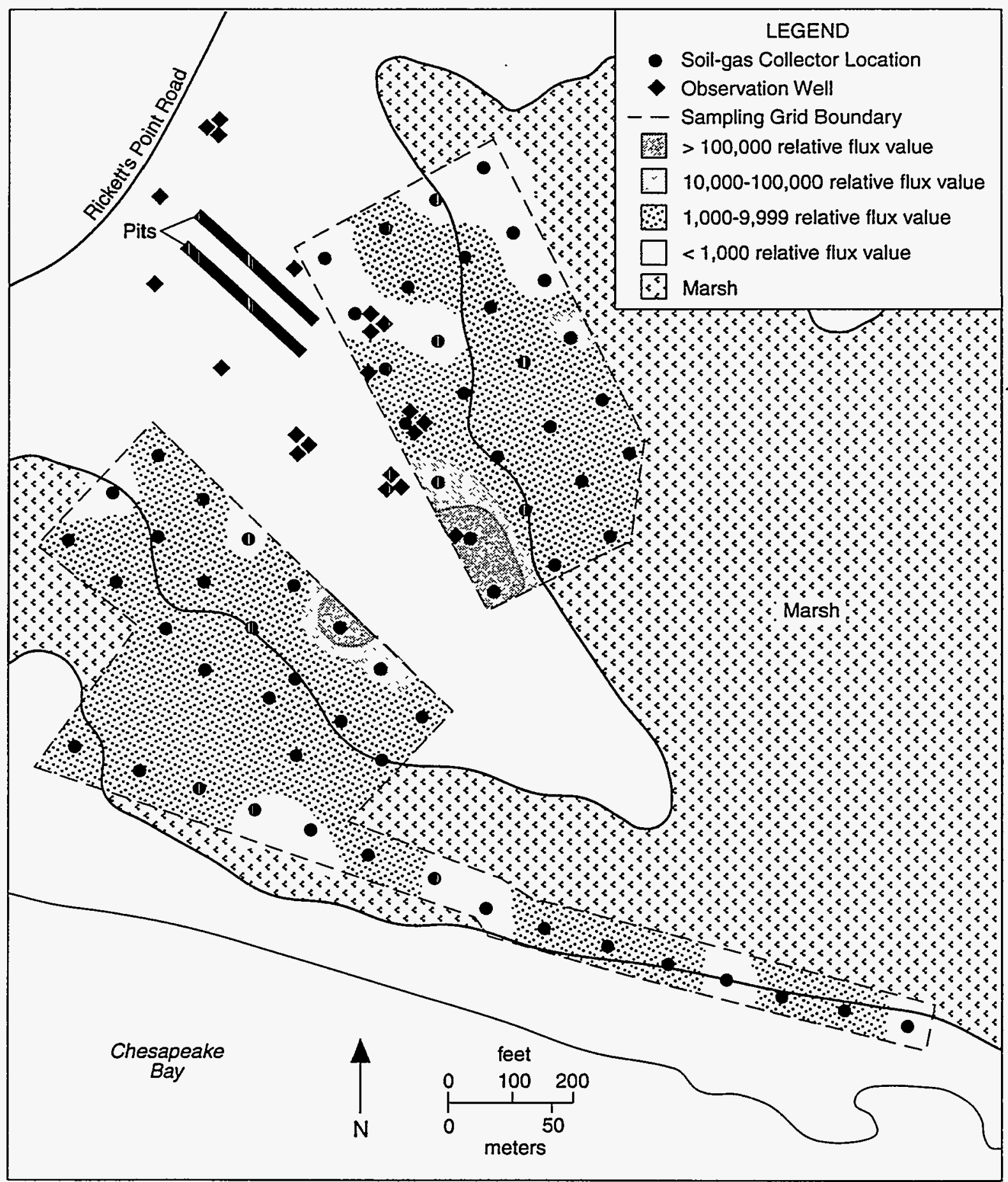

FIGURE 2.8 Relative Contours for Heavy Aromatics in Soil Gas from the Toxic Burning Pits Area (Source: Adapted from Hughes 1993) 
TABLE 2.2 Analytical Results for Analysis of Soil Samples from the Toxic Burning Pits AOC Main Burning Pits, January 1983

\begin{tabular}{|c|c|c|c|}
\hline \multirow[b]{2}{*}{ Parameter $^{\mathbf{a}}$} & \multicolumn{3}{|c|}{$\begin{array}{l}\text { Parameter Concentrations } \\
\text { (mg/kg except as noted) }\end{array}$} \\
\hline & $\begin{array}{l}\text { Back- } \\
\text { ground }\end{array}$ & Pit $1^{c}$ & Pit $2^{\mathrm{c}}$ \\
\hline Arsenic & $<0.481$ & 3.56 & $<0.53$ \\
\hline Barium & 110 & 247 & 257 \\
\hline Cadmium & 0.84 & 4.46 & 2.19 \\
\hline Chromium & 74.70 & 413 & 192 \\
\hline Iron & 6,000 & 18,900 & 17,000 \\
\hline Lead & 76.90 & 717 & 281 \\
\hline Manganese & 153 & 169 & 206 \\
\hline Mercury & 0.034 & 0.080 & 0.008 \\
\hline Potassium & 857 & 1,450 & 1,650 \\
\hline Zinc & 250 & 1,510 & 810 \\
\hline pH (standard units) & 6.30 & 8.50 & 8.80 \\
\hline Nitrate & 295 & 316 & 249 \\
\hline Total phosphorus & 9.00 & $<0.50$ & $<0.25$ \\
\hline Cyanide & $<0.50$ & $<0.50$ & $<0.50$ \\
\hline $\begin{array}{l}\text { Petroleum } \\
\text { hydrocarbons }\end{array}$ & 113 & 800 & 850 \\
\hline Phenols & 0.37 & $<0.13$ & 0.31 \\
\hline Toluene $(\mu \mathrm{g} / \mathrm{kg})$ & $<20.00$ & 32.00 & 28.00 \\
\hline Ethylbenzene ( $\mu \mathrm{g} / \mathrm{kg})$ & 20.00 & $<20.00$ & $<20.00$ \\
\hline
\end{tabular}

a Table lists all parameters detected at least once.

b Locations of background samples not given.

c Based on available information, it is inferred that Pit 1 is the northern main burning pit and Pit 2 is the southern main burning pit.

Source: Adapted from Princeton Aqua Science (1984). 


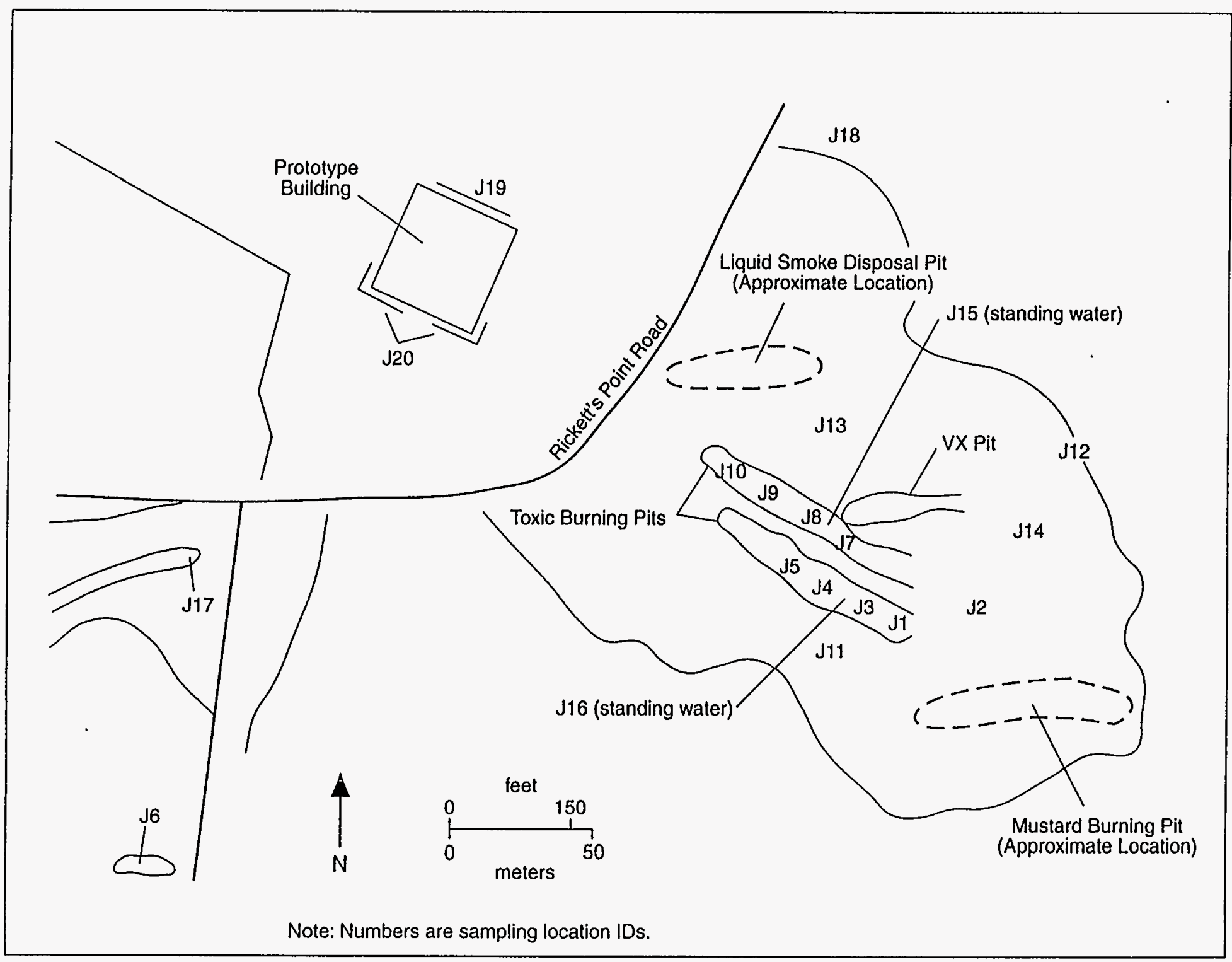

FIGURE 2.9 Locations in the Toxic Burning Pits Area where Surface Soil and Surface Water Samples Were Collected during the 1986 RCRA Facility Assessment (Source: Adapted from Nemeth 1989) 
TABLE 2.3 Analytical Results for Analysis of Soil Samples J1-J20 from the Toxic Burning Pits, 1986

\begin{tabular}{|c|c|c|c|c|c|c|c|c|c|}
\hline Parameter $^{a}$ & J1 & $\mathrm{J}^{\mathrm{b}}$ & J3 & $\mathrm{J} 4$ & J5 & J6 & J7 & J8 & J9 \\
\hline \multicolumn{10}{|c|}{ Total Metals (mg/kg) } \\
\hline Arsenic & 54.8 & 25.2 & 21.5 & 40.5 & 18.5 & 9.7 & 47.3 & 25.7 & 43.9 \\
\hline Barium & 592 & 277 & 313 & 90.5 & 134 & $<60$ & 488 & 172 & 296 \\
\hline Cadmium & 8.13 & 4.57 & 2.52 & 4.88 & 1.58 & 2.20 & 17.3 & 8.64 & 6.10 \\
\hline Chromium & 75.5 & 54.4 & 45.9 & 95.9 & 70.8 & 10.7 & 73.3 & 76.0 & 53.3 \\
\hline Lead & 472 & 548 & 378 & 85.3 & 60.3 & 38.5 & 2,998 & 720 & 1,369 \\
\hline Mercury & 0.78 & 0.87 & 0.46 & 0.15 & 0.22 & 0.17 & 2.16 & 10.8 & 7.29 \\
\hline Silver & 14.0 & $<5.0$ & $<5.0$ & 12.1 & $<5.0$ & $<5.00$ & 15.2 & 7.01 & $<5.0$ \\
\hline \multicolumn{10}{|c|}{ Extractable Metals (mg/L) } \\
\hline Cadmium & $<0.10$ & $<0.10$ & $<0.10$ & $<0.10$ & $<0.10$ & $<0.10$ & 0.228 & $<0.10$ & $<0.10$ \\
\hline Lead & $<0.50$ & $<0.50$ & $<0.50$ & $<0.50$ & $<0.50$ & $<0.50$ & 5.23 & $<0.50$ & $<0.50$ \\
\hline \multirow[t]{2}{*}{ Silver } & $<0.50$ & $<0.50$ & $<0.50$ & $<0.50$ & $<0.50$ & $<0.50$ & $<0.50$ & $<0.50$ & $<0.50$ \\
\hline & J10 & $J 11$ & J12 & J13 & J14 & J17 & J18 & J19 & $\mathrm{J} 20$ \\
\hline \multicolumn{10}{|c|}{ Total Metals (mg/kg) } \\
\hline Arsenic & 32.2 & 12.6 & 24.1 & 8.26 & 28.7 & 15.9 & 6.5 & 9.74 & 12.3 \\
\hline Barium & 208 & 101 & 855 & 107 & 256 & $<60$ & 81.4 & $<60$ & $<60$ \\
\hline Cadmium & 4.75 & 0.27 & 3.57 & 1.01 & 1.47 & 5.02 & $<0.20$ & 5.38 & 16.6 \\
\hline Chromium & 58.0 & 12.1 & 80.1 & 19.2 & 30.4 & 63.9 & 6.65 & 15.4 & 13.5 \\
\hline Lead & 4,101 & 15.8 & 26,040 & 41.8 & 1,522 & 203 & 12.1 & 140 & 1,622 \\
\hline Mercury & 6.10 & 0.11 & 0.77 & 0.11 & 0.59 & 0.20 & $<0.10$ & 0.28 & 3.40 \\
\hline Silver & $<5.0$ & $<5.0$ & $<5.0$ & $<5.0$ & $<5.0$ & 8.64 & $<5.0$ & $<5.0$ & $<5.0$ \\
\hline \multicolumn{10}{|c|}{ Extractable Metals (mg/L) } \\
\hline Cadmium & $<0.10$ & $<0.10$ & $<0.10$ & $<0.10$ & $<0.10$ & $<0.10$ & $<0.10$ & $<0.10$ & 0.112 \\
\hline Lead & $<0.50$ & $<0.50$ & 31.2 & $<0.50$ & $<0.50$ & $<0.50$ & $<0.50$ & $<0.50$ & $<0.50$ \\
\hline Silver & $<0.50$ & $<0.50$ & $<0.50$ & $<0.50$ & 0.154 & $<0.50$ & $<0.50$ & $<0.50$ & $<0.50$ \\
\hline
\end{tabular}

a Includes parameters that were detected in at least one soil sample.

b VOCs were measured in sample J2 only; 1,000 $\mu \mathrm{g} / \mathrm{kg}$ TRCLE and traces of other VOCs were found.

Source: Nemeth (1989). 
Composite samples from locations 1 and 2 contained 13,000 $\mathrm{\mu g} / \mathrm{kg}$ heptachlor epoxide and lower concentrations of other pesticides. Aroclor 1248 (a PCB) was detected at a concentration of $230,000 \mu \mathrm{gg} / \mathrm{kg}$. Composites from locations 3 through 5,7 through 10,19 , and 20 (near the $\mathrm{PB}$ ) also contained pesticides $-1,000 \mu \mathrm{g} / \mathrm{kg}$ each dichlorodiphenyldichloroethane (DDD), dichlorodiphenyldichloroethylene (DDE), and dichlorodiphenyltrichloroethane (DDT) (in locations 19 and 20 only); and $3,700 \mu \mathrm{g} / \mathrm{kg}$ PCBs (locations 3 through 5 only). Hughes (1993) states that detection of pesticides in samples containing PCBs may represent false positives. PCBs reportedly were used as heat-transfer fluids at the Edgewood Area and disposed of at J-Field (Nemeth 1989). Trace concentrations of organic compounds were also detected in samples: TRCLE (at 1,000 $\mu \mathrm{g} / \mathrm{kg}$ ) and traces of other VOCs in the sample from location 2 , the only sample analyzed for VOCs.

Soil samples were collected-by the USGS from depths of approximately $1 \mathrm{ft}$ below land surface at 36 sites in J-Field, including the TBP area (Figure 2.10). The samples were analyzed for indicator parameters, metals, VOCs, semivolatile compounds, and explosives (Hughes 1992). The results of these analyses, except for explosives, are presented in Table 2.4. Soil samples showed some metals contamination, especially at locations 39 and 30, north of the Mustard Pit. Traces of organic compounds were also detected in some samples.

Soil samples were also collected in the TBP area by Weston in October 1992 (Figure 2.11). The samples were collected at depths of 2,4 , and $6 \mathrm{ft}$ in the pits; and at depths of $3 \mathrm{in}$. and $1 \mathrm{ft}$ in the marshes and pushout areas. Tables 2.5 and 2.6 summarize the analytical results for parameters detected in some of these samples.

The highest concentrations of organic compounds were found in the area of the Mustard Pit: TCLEA, up to 3,270,000 $\mathrm{\mu g} / \mathrm{kg}$ at $6 \mathrm{ft} ; 1,1,2$-trichloroethane (112TCE), up to $8,500 \mu \mathrm{g} / \mathrm{kg}$ at $6 \mathrm{ft}$; TCLEE, up to $25,700 \mu \mathrm{g} / \mathrm{kg}$ at $6 \mathrm{ft}$; and trichloroethene, up to $263,000 \mu \mathrm{g} / \mathrm{kg}$ at $6 \mathrm{ft}$. Organic compounds, including TCLEA, 112TCE, acetone methylene chloride, and TRCLE, were detected in the main burning pits (see Table 2.6). High levels of PCBs were detected in the southern main pit (up to $143,000 \mu \mathrm{g} / \mathrm{kg}$ at $2 \mathrm{ft}$ ), the mustard pit (up to $178 \mu \mathrm{g} / \mathrm{kg}$ at $6 \mathrm{ft}$ ), the southern marsh (up to $3,200 \mu \mathrm{g} / \mathrm{kg}$ at $1 \mathrm{ft}$ ), and the pushout area northwest of the main pits (up to $3,800 \mu \mathrm{g} / \mathrm{kg}$ at $1 \mathrm{ft}$ ). The highest concentrations of lead were found in the southern main pit ( $340 \mathrm{mg} / \mathrm{kg}$ at $2 \mathrm{ft}$ ), the mustard pit (121 $\mathrm{mg} / \mathrm{kg}$ at $6 \mathrm{ft}$ ), the southern marsh - $(542 \mathrm{mg} / \mathrm{kg}$ at $1 \mathrm{ft})$, the marsh east of the main pits $(79,800 \mathrm{mg} / \mathrm{kg}$ at $3 \mathrm{in.}$, and the pushout area northwest of the main pits $(1,180 \mathrm{mg} / \mathrm{kg}$ at $3 \mathrm{in}$.$) .$

\subsubsection{Surface Water}

Surface water samples (J15 and J16) were collected from the TBP area as part of the 1986 RFA (Nemeth 1989). Sampling locations are shown in Figure 2.9. Samples were analyzed for metals, explosives-related compounds, inorganic compounds, gross alpha, gross beta, radium-226, radium-228, VOCs, semivolatile compounds, and PCBs. The results are summarized in Table 2.7 for locations $\mathrm{J} 15$ and $\mathrm{J} 16$. 


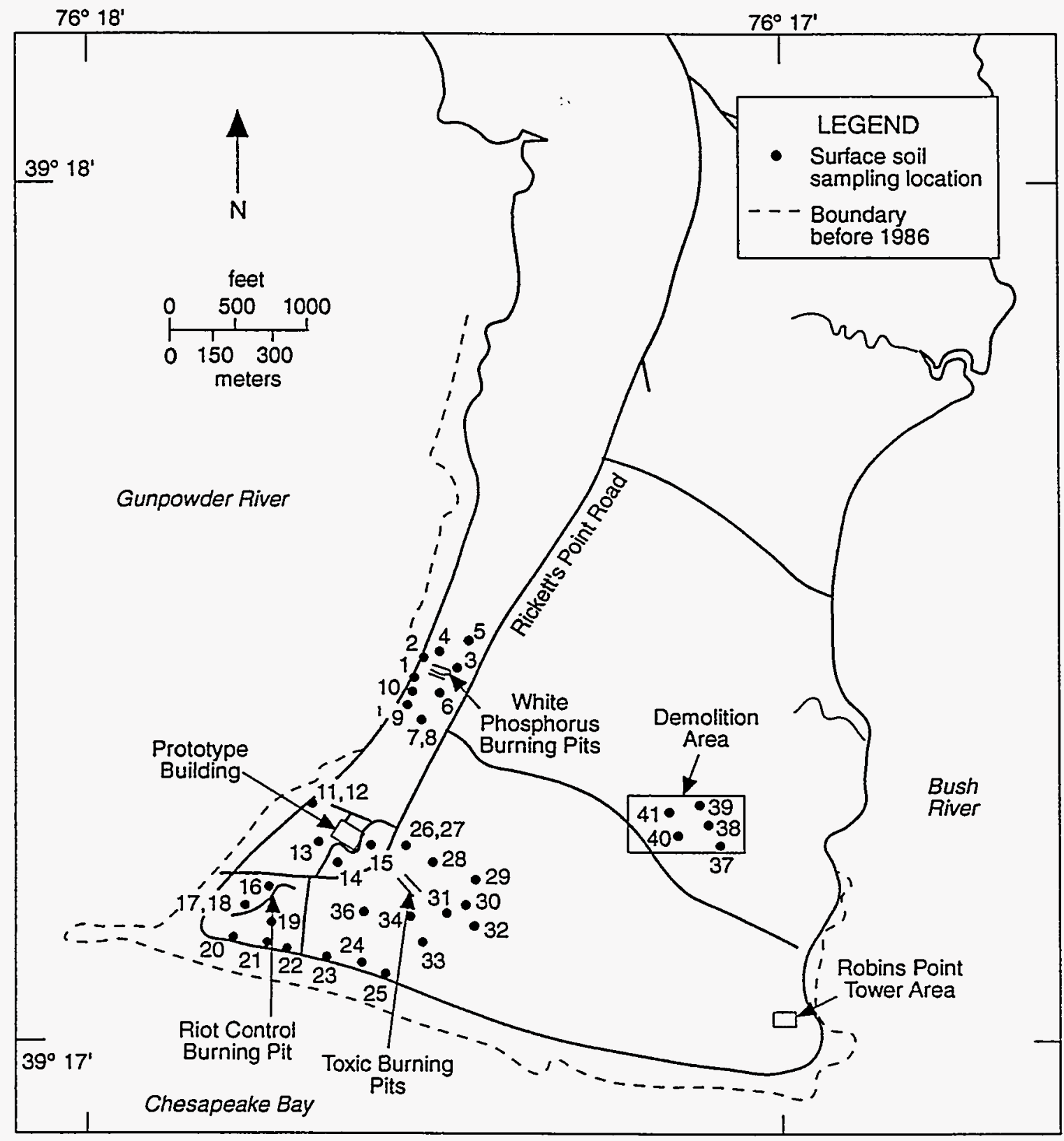

FIGURE 2.10 Locations where Soil Samples Were Collected by the USGS in 1991 (Source: Adapted from Hughes 1992) 
TABLE 2.4 Analytical Results for Analysis of Soil Samples from the Toxic Burning Pits Area, April 1991

\begin{tabular}{|c|c|c|c|c|c|c|c|c|c|c|c|c|c|}
\hline \multirow[b]{2}{*}{ Parameter } & \multicolumn{13}{|c|}{ Concentration by Soil Sample Location ${ }^{\text {b }}$} \\
\hline & 23 & 24 & 25 & 26 & 27 & 28 & 29 & 30 & 31 & 32 & 33 & 34 & 36 \\
\hline \multicolumn{14}{|l|}{ Metals (mg/kg) } \\
\hline Arsenic & 3.7 & 3.2 & ND & 4.5 & 4.2 & 7.8 & 49 & 21 & 2.6 & 3.3 & 3.5 & 6.6 & 3.2 \\
\hline Cadmium & ND & ND & ND & ND & ND & 2.4 & 16 & ND & ND & ND & ND & ND & ND \\
\hline Chromium & 14 & 11 & 6.6 & 16 & 15 & 37 & 121 & 46 & 12 & 13 & 13 & 17 & 17 \\
\hline Copper & 21 & 50 & 10 & 22 & 19 & 233 & 786 & 48 & 4.2 & 11 & 15 & 40 & 17 \\
\hline Lead & 17 & 40 & 14 & 41 & 38 & 662 & 87,100 & 952 & 15 & 17 & 29 & 42 & 19 \\
\hline Antimony & ND & ND & ND & ND & ND & ND & 1,120 & ND & ND & ND & $\mathrm{ND}$ & ND & ND \\
\hline Zinc & ND & ND & 20 & 96 & 157 & ND & 7,960 & $\mathrm{ND}$ & 25 & ND & $\mathrm{ND}$ & ND & ND \\
\hline \multicolumn{14}{|c|}{ Volatile Organic Compounds ( $\mu \mathrm{g} / \mathrm{kg}$ ) } \\
\hline Acetone & 5.89 & 13.9 & 6.73 & 15.8 & 6.75 & 9.80 & 15.7 & 4.88 & 2.24 & ND & 21.0 & ND & ND \\
\hline cis-1,2-dichloroethylene & NA & NA & NA & NA & NA & 2.4 & NA & 2.40 & NA & NA & NA & NA & NA \\
\hline Trichloroethylene & ND & ND & ND & ND & ND & 1.12 & ND & ND & ND & ND & ND & ND & ND \\
\hline \multicolumn{14}{|c|}{ Semivolatile Organic Compounds (ug/kg) } \\
\hline Butylbenzl phthalate & ND & 598 & ND & ND & 720 & ND & 580 & ND & ND & ND & ND & ND & ND \\
\hline Benzoic acid & 353 & 7,000 & 1,500 & ND & ND & ND & 420 & 420 & ND & ND & 2,100 & ND & ND \\
\hline \multicolumn{14}{|l|}{ Other (mg/kg) } \\
\hline Total Kjeldahl nitrogen & 1,040 & 2,340 & 695 & 249 & 247 & 637 & 605 & 488 & 627 & 1,030 & 1,730 & 639 & 552 \\
\hline Total organic carbon & 958 & 2,590 & 1,630 & 1,190 & 1,720 & 1,590 & 1,630 & 1,190 & 1,390 & 871 & 1,810 & 752 & 1,010 \\
\hline Total organic halogen & ND & ND & 157 & 20 & 48 & 37 & 34 & ND & ND & ND & ND & ND & ND \\
\hline
\end{tabular}

a $\mathrm{ND}=$ not detected; NA = not analyzed.

b Locations are shown in Figure 2.10.

Source: Hughes (1992). 


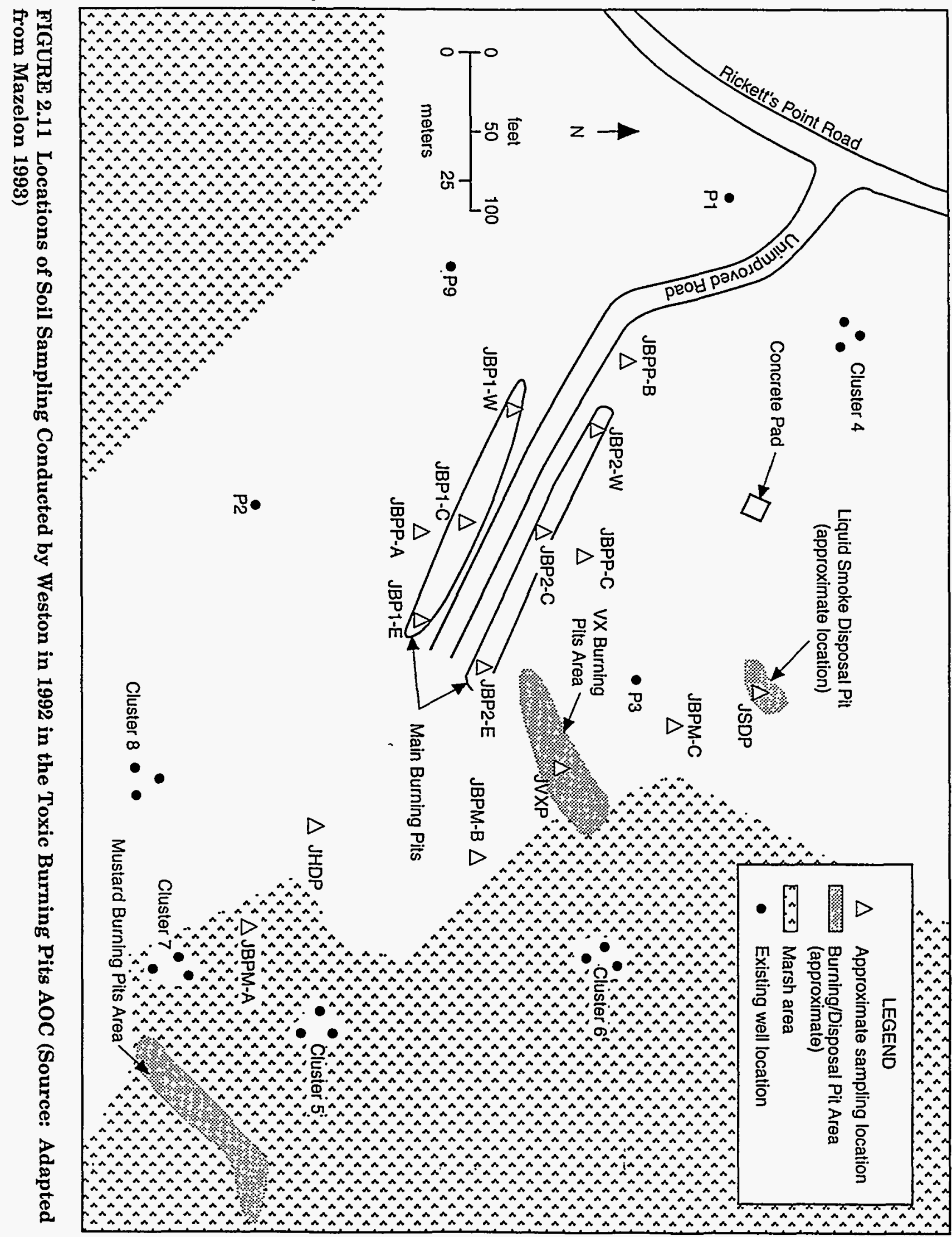


TABLE 2.5 Analytical Results for Target Compound List Analytes in Selected Soil Samples from the Toxic Burning Pits, $1992^{\mathrm{a}}$

Concentrations ( $\mu \mathrm{g} / \mathrm{kg}$ ) by Soil Sample Location

\begin{tabular}{|c|c|c|c|c|c|c|c|c|}
\hline $\mathrm{TCL}^{\mathrm{b}}$ Analyte & JBP1-E $\left(2^{\prime}\right)^{c}$ & JBP1-E(4') & JBP2-E(2') & JBP2-E(4') & $\operatorname{JVXP}\left(4^{\prime}\right)$ & $\operatorname{JVXP}\left(6^{\prime}\right)$ & $\operatorname{JSDP}\left(4^{\prime}\right)$ & $\operatorname{JSDP}\left(6^{\prime}\right)$ \\
\hline \multicolumn{9}{|l|}{ Volatile Organic Compounds } \\
\hline 1,1,2,2-Tetrachloroethane & 6.74 & $\mathrm{ND}^{\mathrm{d}}$ & ND & $\mathrm{ND}$ & 167 & 39 & 15,200 & 25.6 \\
\hline 1,1,2-Trichloroethane & ND & ND & $\mathrm{ND}$ & $\mathrm{ND}$ & ND & ND & 80.5 & ND \\
\hline 1,1-Dichloroethane & $\mathrm{ND}$ & ND & ND & $\mathrm{ND}$ & ND & $\mathrm{ND}$ & ND & ND \\
\hline 1,1-Dichloroethylene & ND & ND & ND & ND & $\mathrm{ND}$ & ND & ND & ND \\
\hline 1,2-Dichloroethane & ND & ND & ND & ND & $\mathrm{ND}$ & ND & ND & ND \\
\hline Acetone & 16.4 & 33 & 44.7 & 116 & ND & ND & 344 & ND \\
\hline Benzene & $\mathrm{ND}$ & ND & ND & ND & $\mathrm{ND}$ & ND & ND & ND \\
\hline Carbon tetrachloride & ND & ND & $\mathrm{ND}$ & $\mathrm{ND}$ & $\mathrm{ND}$ & ND & ND & ND \\
\hline Chloroform & ND & $\mathrm{ND}$ & ND & ND & $\mathrm{ND}$ & ND & ND & ND \\
\hline Methylene chloride & ND & 6.23 & ND & 6.30 & 7.03 & 8.25 & 44.0 & 12.4 \\
\hline Tetrachloroethylene & $\mathrm{ND}$ & ND & $\mathrm{ND}$ & ND & $\mathrm{ND}$ & ND & $\mathrm{ND}$ & $\mathrm{ND}$ \\
\hline Toluene & ND & ND & $\mathrm{ND}$ & $\mathrm{ND}$ & $\mathrm{ND}$ & ND & $\mathrm{ND}$ & ND \\
\hline trans-1,2-Dichloroethylene & $\mathrm{ND}$ & ND & $\mathrm{ND}$ & $\mathrm{ND}$ & ND & ND & 78.0 & ND \\
\hline Trichloroethylene & 28.1 & $\mathrm{ND}$ & $\mathrm{ND}$ & ND & ND & 15.8 & 345 & ND \\
\hline Vinyl chloride & ND & ND & ND & ND & ND & ND & ND & ND \\
\hline Xylenes & 12.4 & ND & ND & ND & ND & ND & ND & ND \\
\hline \multicolumn{9}{|c|}{ Semivolatile Organic Compounds } \\
\hline 2-Methylnaphthalene & 471 & ND & $\mathrm{ND}$ & ND & $\mathrm{ND}$ & ND & ND & ND \\
\hline Hexachloroethane & $\mathrm{ND}$ & ND & ND & ND & $\mathrm{ND}$ & ND & ND & ND \\
\hline Pyrene & 580 & ND & ND & ND & $\mathrm{ND}$ & ND & $\mathrm{ND}$ & $\mathrm{ND}$ \\
\hline \multicolumn{9}{|l|}{$P C B 8$} \\
\hline Aroclor 1248 & 143,000 & 1,180 & ND & ND & ND & ND & ND & $\mathrm{ND}$ \\
\hline Aroclor 1254 & $\mathrm{ND}$ & ND & 224 & ND & ND & ND & ND & ND \\
\hline
\end{tabular}




\begin{tabular}{|c|c|c|c|c|c|c|}
\hline \multirow[b]{2}{*}{ TCL Analyte } & \multicolumn{6}{|c|}{ Concentration $(\mu \mathrm{g} / \mathrm{kg}$ ) by Soil Sample Location } \\
\hline & $\operatorname{JHDP}\left(4^{\prime}\right)$ & $\operatorname{JHDP}\left(6^{\circ}\right)$ & JBPM-A(3") & JBPM-A(1) & JBPM-B(3") & JBPM-B(1) \\
\hline \multicolumn{7}{|l|}{ Volatile Organic Compounds } \\
\hline 1,1,2,2-Tetrachloroethane & 289,000 & $3,270,000$ & 123 & 1,460 & 13,200 & 15,200 \\
\hline 1,1,2-Trichloroethane & 2,100 & 8,540 & 61.0 & $\mathrm{ND}$ & 80.2 & ND \\
\hline 1,1-Dichloroethane & ND & 8.99 & ND & ND & ND & ND \\
\hline 1,1-Dichloroethylene & 31.3 & 77.6 & ND & ND & ND & ND \\
\hline 1,2-Dichloroethane & 40.1 & 62.4 & ND & ND & ND & $\mathrm{ND}$ \\
\hline Acetone & 177 & 113 & 275 & ND & 324 & ND \\
\hline Benzene & 19.1 & 83.1 & ND & ND & ND & ND \\
\hline Carbon tetrachloride & 17.1 & 172 & $\mathrm{ND}$ & ND & ND & $\mathrm{ND}$ \\
\hline Chloroform & 142 & 445 & ND & ND & $\mathrm{ND}$ & ND \\
\hline Methylene chloride & 44.9 & 41.2 & 36.1 & ND & 36.2 & ND \\
\hline Tetrachloroethylene & ND & 25,700 & ND & $\mathrm{ND}$ & ND & ND \\
\hline Toluene & $\mathrm{ND}$ & ND & ND & ND & ND & ND \\
\hline trans-1,2-Dichloroethylene & 3,860 & 3,220 & ND & ND & 50.4 & ND \\
\hline Trichloroethylene & 6,780 & 263,000 & 843 & 26,000 & 517 & ND \\
\hline Vinyl chloride & 315 & 302 & ND & ND & ND & ND \\
\hline Xylenes & $\mathrm{ND}$ & ND & ND & ND & ND & ND \\
\hline \multicolumn{7}{|c|}{ Semivolatile Organic Compounds } \\
\hline 2-Methylnaphthalene & $\mathrm{ND}$ & ND & ND & ND & ND & ND \\
\hline Hexachloroethane & ND & 628 & ND & 498 & ND & $\mathrm{ND}$ \\
\hline Pyrene & ND & $\mathrm{ND}$ & ND & ND & ND & $\mathrm{ND}$ \\
\hline \multicolumn{7}{|l|}{ PCBs } \\
\hline Aroclor 1248 & ND & 178 & ND & ND & ND & $\mathrm{ND}$ \\
\hline Aroclor 1254 & ND & $\mathrm{ND}$ & 1,700 & 3,160 & ND & ND \\
\hline
\end{tabular}

a Only detected analytes are reported; for samples with duplicate analyses, the higher value is reported. ..

b TCL $=$ Target Compound List.

c Sample depth shown in parentheses.

d $\mathrm{ND}=$ not detected.

Source: Weston (1992). 
TABLE 2.6 Analytical Results for Target Analyte List Analytes in Selected Soil Samples from the Toxic Burning Pits, $1992^{\mathrm{a}}$

\begin{tabular}{|c|c|c|c|c|c|c|c|}
\hline \multirow{2}{*}{$\begin{array}{c}\text { TAL }^{\mathrm{b}} \\
\text { Analyte }\end{array}$} & \multicolumn{7}{|c|}{ Concentration (mg/kg) by Soil Sample Location } \\
\hline & JBP1-E $\left(2^{\prime}\right)^{\mathbf{c}}$ & JBP1-E(4) & JBP2-E(2') & JBP2-E(4') & $\operatorname{JVXP}\left(4^{\prime}\right)$ & $\operatorname{JVXP}\left(6^{\prime}\right)$ & $\operatorname{JSDP}\left(4^{\prime}\right)$ \\
\hline Antimony & 5.08 & $\mathrm{ND}^{\mathrm{d}}$ & $\mathrm{ND}$ & ND & ND & ND & ND \\
\hline Arsenic & 5.02 & 4.18 & 3.50 & 2.33 & 1.19 & ND & 1.38 \\
\hline Beryllium & 0.309 & 0.453 & 0.228 & 0.380 & ND & ND & ND \\
\hline Cadmium & 3.21 & ND & ND & ND & ND & ND & ND \\
\hline Chromium & 36.6 & 18.2 & 14.2 & 12.7 & 5.33 & 3.15 & 4.09 \\
\hline Cobalt & 5.64 & ND & ND & ND & ND & ND & ND \\
\hline Copper & 248 & 10.1 & 6.85 & 10.1 & ND & ND & ND \\
\hline Lead & 340 & 10.5 & 15.9 & 96.3 & 10.5 & 2.6 & 3.37 \\
\hline Zinc & 1,220 & 123 & 94.4 & 76.5 & 33.8 & 13.1 & 13.5 \\
\hline
\end{tabular}

Concentration $(\mathrm{mg} / \mathrm{kg})$ by Soil Sample Location

\begin{tabular}{|c|c|c|c|c|c|c|c|}
\hline $\begin{array}{c}\text { TAL } \\
\text { Analyte }\end{array}$ & $\operatorname{JSDP}\left(6^{\prime}\right)$ & JHDP(4') & JHDP(6 $6^{\prime}$ & JBPM-A(3") & JBPM-A(1') & JBPM-B(3") & JBPM-B(1') \\
\hline Antimony & ND & ND & $\mathrm{ND}$ & ND & ND & 13.7 & ND \\
\hline Arsenic & ND & 3.94 & 6.29 & 4.80 & 22.5 & 7.49 & 3.58 \\
\hline Beryllium & ND & 0.457 & 0.408 & 0.434 & 0.263 & 0.339 & 0.398 \\
\hline Cadmium & $\mathrm{ND}$ & $\mathrm{ND}$ & 7.23 & 2.95 & 6.05 & 5.94 & ND \\
\hline Chromium & 5.54 & 11.9 & 44.1 & 37.8 & 67.9 & 53.4 & 15.6 \\
\hline Cobalt & ND & ND & ND & ND & ND & 6.41 & $\mathrm{ND}$ \\
\hline Copper & ND & $\mathrm{ND}$ & 123 & 305 & 392 & 521 & 4.77 \\
\hline Lead & 8.22 & 10.5 & 121 & 145 & 542 & 79,800 & 11.2 \\
\hline Zinc & 12.8 & 25.1 & 296 & 690 & 678 & 1,000 & 46.9 \\
\hline
\end{tabular}

a Only detected analytes are reported; for samples with duplicate analyses, the higher value is reported.

b $\mathrm{TAL}=$ Target Analyte List.

c Sample depth shown in parentheses.

d $\mathrm{ND}=$ not detected.

Source: Mazelon (1993). 
TABLE 2.7 Analytical Results for Surface Water Samples from the Toxic Burning Pits Area, 1986

\begin{tabular}{|c|c|c|}
\hline \multirow[b]{2}{*}{ Parameter $^{\mathrm{a}}$} & \multicolumn{2}{|c|}{ Location } \\
\hline & J15 & J16 \\
\hline \multicolumn{3}{|l|}{ Dissolved Metals ( $\mu g / L)$} \\
\hline Cadmium & $<1.0$ & 2.0 \\
\hline Lead & 40 & 104 \\
\hline Mercury & 0.60 & $<0.20$ \\
\hline \multicolumn{3}{|c|}{ Inorganic Compounds ( $\mu g / L)$} \\
\hline Nitrate and nitrite as $\mathrm{N}^{\mathrm{b}}$ & $<30$ & 60 \\
\hline Sulfate & 12,000 & 16,000 \\
\hline Chloride & 3,000 & 4,000 \\
\hline Total dissolved solids & $N^{c}$ & 34,000 \\
\hline \multicolumn{3}{|l|}{ Radioactivity (pCi/L) } \\
\hline Gross alpha & $<0.8$ & 7.0 \\
\hline Gross beta & 5.7 & 15 \\
\hline Radium-226 & NA & 0.50 \\
\hline Radium-228 & NA & 1.4 \\
\hline
\end{tabular}

a Includes parameters that were detected in one or more samples. No detection limits given for VOCs, semivolatile compounds, and PCBs.

b $\mathrm{N}=$ nitrogen.

c $\mathrm{NA}=$ not analyzed.

Source: Nemeth (1989).

The surface water contained some lead contamination. The lead concentration at location 16 was above the primary drinking water standard $(50 \mu \mathrm{g} / \mathrm{L})$. The gross alpha radionuclide was also slightly elevated at location 16 . The radioactivity measurements were consistent with results from a field radiation survey of the TBP for materials emitting beta and gamma radioactivity. No radiation above background levels was detected (Nemeth 1989).

The USGS collected nearshore surface water samples from the Gunpowder River (9 locations) and the Chesapeake Bay (11 locations) at low tide. One sample was collected onshore in a drainage ditch. Sampling locations are shown in Figure 2.12. Filtered and unfiltered samples were analyzed for water quality parameters, metals, and a few organic compounds. Nitrate concentrations in samples from locations 3, 7, and 13 ranged from 280 to $400 \mu \mathrm{g} / \mathrm{L}$. The metals data showed the presence of lead (from not detected [ND] ${ }^{2}$ to $28 \mu \mathrm{g} / \mathrm{L})$ and zinc (50-133 $\mathrm{\mu g} / \mathrm{L})$ at locations 1 through 4 . Lead and zinc concentrations at the

2 The detection limits for analyses were not reported. 


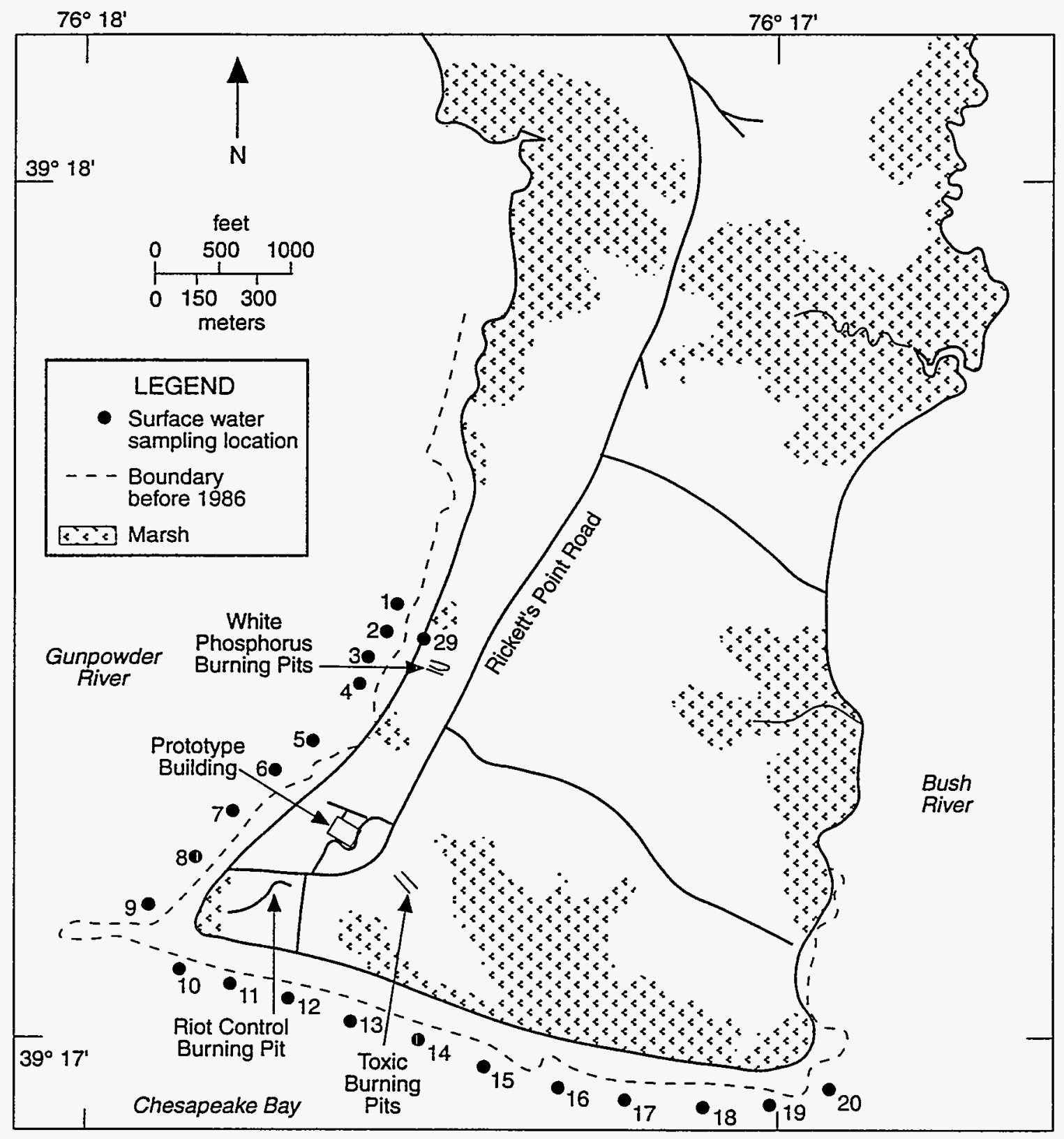

FIGURE 2.12 Locations of Surface Water Samples Collected at J-Field in 1988 (Source: Adapted from USGS 1991) 
other locations ranged from ND to 2.68 and $48 \mu \mathrm{g} / \mathrm{L}$, respectively. Mercury and nickel concentrations were slightly elevated at location 1 ( 0.54 and $33.7 \mu \mathrm{g} / \mathrm{L}$, respectively). No evidence was found of elevated concentrations of arsenic, barium, or chromium. Comparison of results from filtered and unfiltered samples showed that the elevated metals concentrations may be associated with the suspended solids in the samples (Hughes 1993).

Acetone, toluene, phenol, total organic carbon (TOC), and total organic halogen (TOX) were analyzed in the filtered and unfiltered samples from nine locations. Phenol (ND to $51.9 \mu \mathrm{g} / \mathrm{L})$, TOC $(4,000-7,000 \mu \mathrm{g} / \mathrm{L})$, and TOX $(21.6-30.4 \mu \mathrm{g} / \mathrm{L})$ were detected in the unfiltered samples only. The presence of acetone in some of the samples may represent laboratory contamination. Toluene $(3.05 \mu \mathrm{g} / \mathrm{L})$ was found at location 1 (Hughes 1993).

The data for the nearshore surface water have shown essentially no contamination. Contaminants appear to be associated with the suspended solids, suggesting that the nearshore sediments may be contaminated.

In August 1992, the EPA emergency response team collected nearshore surface water and sediment samples at 17 locations around the peninsula - in the Gunpowder and Bush rivers and in Chesapeake Bay (Figure 2.13). Filtered surface water samples were analyzed for VOCs, base neutral and acid extractable organic compounds (BNA), Target Analyte List (TAL) metals, pesticides, PCBs, and inorganic parameters (sulfate, total Kjeldahl nitrogen [TKN], total phosphorus, and cyanide). The data showed that beryllium, lead, and mercury were below their respective detection limits of $6,000,6,000$, and $200 \mu \mathrm{g} / \mathrm{L}$. Zinc concentrations ranged from $11,000 \mu \mathrm{g} / \mathrm{L}$ at locations 3,4 , and 16 to $96,000 \mu \mathrm{g} / \mathrm{L}$ at location 6 . Nickel concentrations ranged from $28,000 \mu \mathrm{g} / \mathrm{L}$ at most locations to $38,000 \mu \mathrm{g} / \mathrm{L}$ at location 9 . No cyanide, VOCs, pesticides, or PCBs were detected.

Sediment samples, collected at the same locations as the surface water, were analyzed for CWAs and CWA degradation products, explosives, VOCs, BNA, TAL metals, pesticides, PCBs, and other parameters (TOC, sulfate, total phosphorus, TKN, and percent solids). The results indicate that there is essentially no contamination in sediments at these locations, although lead was detected at concentrations ranging from $2 \mathrm{mg} / \mathrm{L}$ at location 11 to $22 \mathrm{mg} / \mathrm{L}$ at location 17 . Arsenic and cadmium were also detected: arsenic at concentrations ranging from 1 to $6 \mathrm{mg} / \mathrm{L}$ (at location 6) and cadmium at concentrations ranging from $<0.5$ to $3 \mathrm{mg} / \mathrm{L}$ (at location 8). The detection limit for beryllium was fairly high, ranging from 0.5 to $2.6 \mathrm{mg} / \mathrm{L}$. The only VOC detected was acetone, up to $101 \mu \mathrm{gg} / \mathrm{kg}$ at location 7.

\subsubsection{Groundwater}

Eleven groundwater monitoring wells (TH series) were installed in J-Field during the 1977 environmental survey. Locations of these wells are shown in Figure 2.14. Only one well (TH4) was installed in the area of the TBP. Well depths ranged from 20 to $25 \mathrm{ft}$. The wells were screened in the surficial aquifer with 25-ft-long screens (Sonntag 1991). Samples 


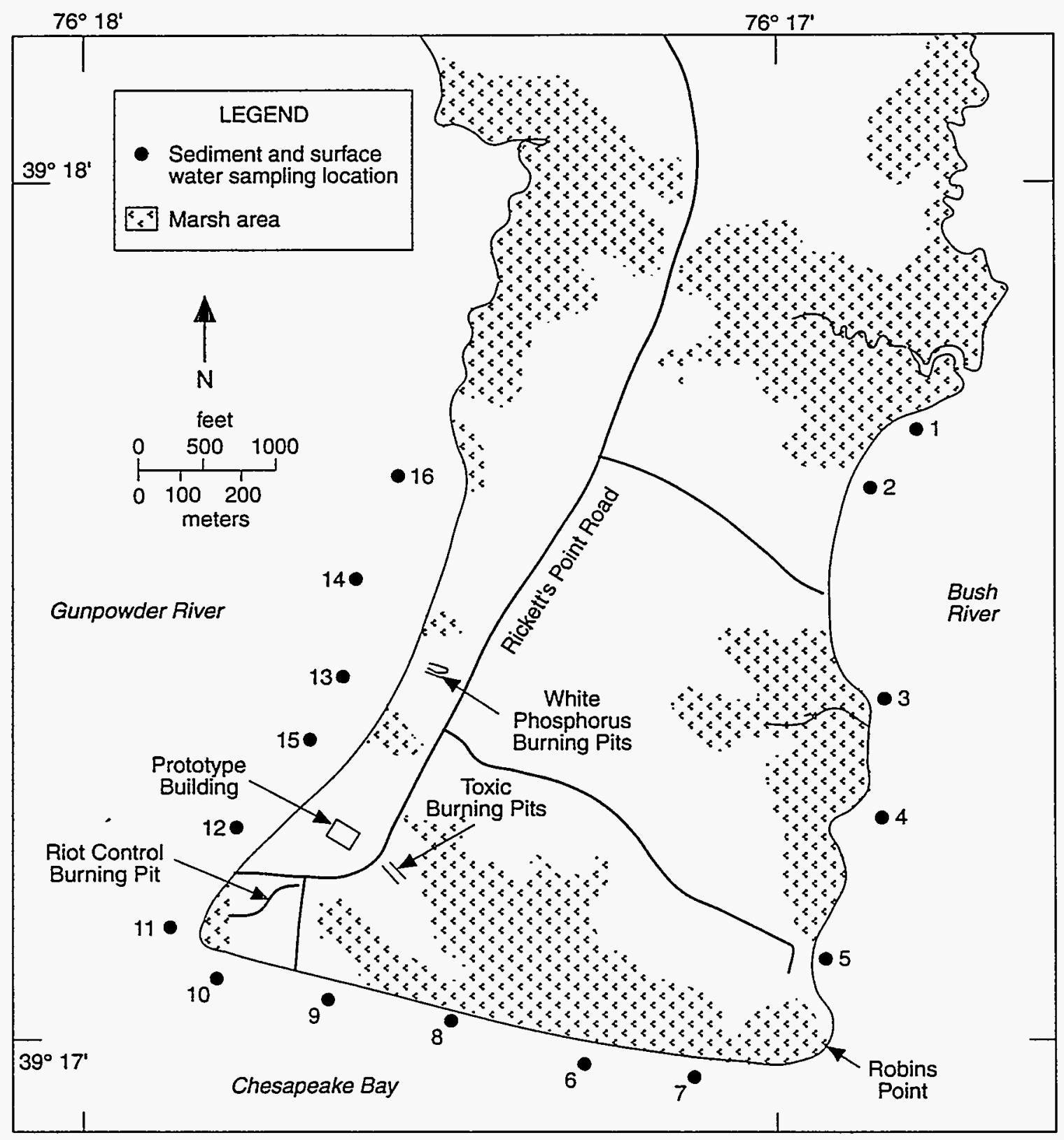

FIGURE 2.13 Locations of Surface Water and Sediment Samples Collected at J-Field in 1992 (Source: EPA 1992) 


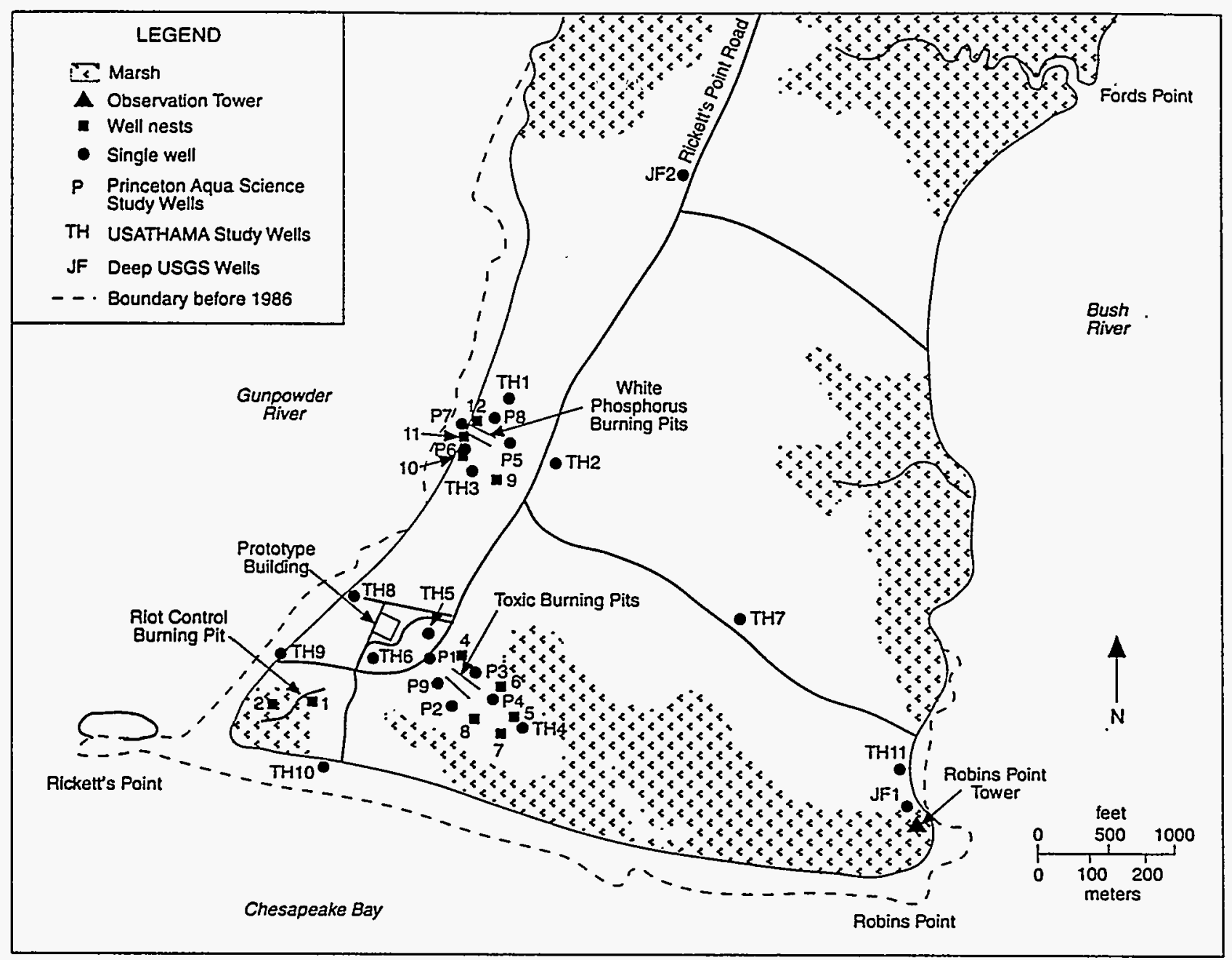

FIGURE 2.14 Locations of All Wells Installed at J-Field (Source: Adapted from Hughes 1993)

collected from the wells in 1977 were analyzed for metals, inorganic chemicals, white phosphorus, mustard degradation products, cholinesterase inhibitors, semivolatile compounds, and VOCs. Organic contaminants (up to $200,000 \mu \mathrm{g} / \mathrm{L}$ ) were found in all of the wells (no data were given for $\mathrm{TH} 7$ ).

Five additional wells were installed around the TBP as part of a munitions disposal study (Figure 2.14, P series) (Princeton Aqua Science 1984). The wells were screened in the surficial aquifer from depths of $17-20 \mathrm{ft}$ with 15-ft-long screens (Sonntag 1991). Water samples collected from the wells in 1983 were analyzed for metals, nitrate, TOX, TOC, radioactivity, pesticides, herbicides, and secondary drinking water parameters. Two of the five wells (P4 and P5) contained elevated concentrations of the gross beta radionuclide (140 and $12 \mathrm{pCi} / \mathrm{L}$, respectively). Two wells (P3 and P4) contained TOX (6.6 and $7.1 \mathrm{mg} / \mathrm{L}$, respectively). Two wells (P2 and $\mathrm{P} 5$ ) contained elevated concentrations of nitrates (12 and $10 \mathrm{mg} / \mathrm{L}$, respectively). 
The P-series wells were sampled again in 1986 as part of the Edgewood Area RFA (Nemeth 1989). The samples were analyzed for metals, explosives-related compounds, inorganic compounds, radioactivity, thiodiglycol, VOCs, semivolatile compounds, and PCBs. The results are summarized in Table 2.8. Elevated concentrations of VOCs were found in only two wells (P3 and P4), near the area exhibiting soil-gas contamination. The compounds found include trans-1,2-dichloroethylene (trans-12DCE), up to 8,500 $\mu / \mathrm{L}$ in well P4; TRCLE, up to $6,700 \mu \mathrm{g} / \mathrm{L}$ in well $\mathrm{P} 4$; vinyl chloride, up to $550 \mu \mathrm{g} / \mathrm{L}$ in well P3; and TCLEE, up to $420 \mathrm{\mu g} / \mathrm{L}$ in well P3. The data also indicate that the elevated gross beta activity detected in well P3 was due to naturally occurring potassium-40; however, it is not clear why potassium concentrations were so much higher in this well than in the others.

Thirty-eight additional monitoring wells were installed by the USGS in 1988 and 1989 (Sonntag 1991; Hughes 1993). Two of these wells, JF1 and JF2, were installed and screened in the Potomac Group. The 36 other wells were placed in nests of 3 at 12 different locations (Figure 2.14). Well nests JF3-JF8 were placed in the TBP area. The nested wells were screened in the confined aquifer, the leaky confining unit, and the surficial aquifer. The naming convention for the well nests involves a combination of letters and numbers. The letters with numbers (i.e., JF1-JF12) indicate the location. This location indicator code is then coupled with the numbers 1,2 , or 3 to indicate the strata being monitored. The confined aquifer is designated by the number 1 , the leaky confining unit by the number 2 , and the surficial aquifer by the number 3 .

During 1990, samples from 55 of the 58 existing wells at J-Field were analyzed for metals, inorganic compounds, VOCs, and semivolatile organic compounds. Several of the wells were also analyzed for organosulfur, explosives, and radioactive contaminants. Wells were selected for specific contaminant analyses on the basis of the nature of disposal activities that had occurred nearby (USGS 1991).

Table 2.9 summarizes the analytical results indicating the presence of metals and other inorganic compounds. Concentrations of lead (124 $\mathrm{\mu g} / \mathrm{L}$ ) in well P9 and arsenic $(60 \mu \mathrm{g} / \mathrm{L})$ in well JF83 exceed maximum contaminant levels (MCLs). Both of these wells are downgradient from the TBP. Potassium concentrations ranged from not detected to $140 \mu \mathrm{g} / \mathrm{L}$. Except for one measurement at well P3, the elevated concentrations of potassium (above $50 \mu \mathrm{g} / \mathrm{L}$ ) occurred in the leaky confining unit or the confined aquifer. Movement of sea water into the groundwater may not be a source of potassium because wells with elevated potassium do not have elevated chloride concentrations.

The analytical results (summarized in Table 2.10) show that the TBP are contaminated with VOCs, and a contaminant plume in the groundwater extends downgradient to the southeast. This condition is reflected in the elevated concentrations of 112TCE, 1,2-dichloroethylene (12DCE), TCLEA, TCLEE, and TRCLE in well nests JF5, JF7, and JF8. The concentrations are highest in the surficial aquifer - up to $7,150 \mu \mathrm{g} / \mathrm{L} 12 \mathrm{DCE}$ in wells JF73 and JF83. The data also show that some contamination extends down into the leaky confining unit and the confined aquifer $(1,400 \mu \mathrm{g} / \mathrm{L}$ TRCLE in the leaky confining unit 
TABLE 2.8 Analytical Results for Groundwater from the P-Series Monitoring Wells, 1986

\begin{tabular}{|c|c|c|c|c|c|}
\hline \multirow[b]{2}{*}{ Parameter ${ }^{\mathrm{a}}$} & \multicolumn{5}{|c|}{ Concentration by Well } \\
\hline & P1 & $\mathrm{P} 2$ & P3 & P4 & P9 \\
\hline \multicolumn{6}{|c|}{ Dissolved Metals ( $\mu g / L)$} \\
\hline Arsenic & $<10$ & $<10$ & 24 & $<10$ & $<10$ \\
\hline Cadmium & $<1$ & $<1$ & $<1$ & 3 & $<1$ \\
\hline Lead & $<5$ & $<5$ & $<5$ & 90 & $<5$ \\
\hline Selenium & $<5$ & 9 & 54 & 26 & $<5$ \\
\hline Potassium & 1,040 & 733 & 113,000 & 1,380 & 782 \\
\hline \multicolumn{6}{|c|}{ Inorganic Compounds ( $\mu g / L)$} \\
\hline Nitrate/nitrite as $\mathrm{N}$ & 490 & 12,000 & $<50$ & $<50$ & 8,000 \\
\hline Sulfate & 54,000 & 105,000 & 362,000 & 93,000 & 94,000 \\
\hline Chloride & 4,800 & 23,000 & 304,000 & 866,000 & 24,000 \\
\hline Total phosphate as $\mathrm{P}$ & $\mathrm{NA}^{\mathrm{b}}$ & NA & NA & NA & NA \\
\hline Total dissolved solids & 125,000 & 328,000 & $1,403,000$ & $1,087,000$ & 262,000 \\
\hline \multicolumn{6}{|l|}{ Radioactivity ( $p C i / L$ ) } \\
\hline Gross beta & 1.3 & 2.5 & 100 & $<4.8$ & 1.4 \\
\hline Potassium-40 & NA & NA & 120 & NA & NA \\
\hline Radium-226 & NA & NA & 0.43 & NA & NA \\
\hline \multicolumn{6}{|c|}{ Volatile Organic Compounds ( $\mu g / L)$} \\
\hline Benzene & $\mathrm{ND}^{\mathrm{c}}$ & ND & 6.0 & ND & ND \\
\hline Chlorobenzene & ND & ND & 980 & ND & ND \\
\hline Ethyl benzene & ND & ND & 3.0 & ND & ND \\
\hline Toluene & ND & ND & 5.0 & ND & ND \\
\hline Chloroform & ND & ND & 7.0 & 3.0 & ND \\
\hline Carbon tetrachloride & ND & 5.0 & ND & ND & ND \\
\hline $112 \mathrm{TCE}$ & ND & ND & 7.0 & 130 & ND \\
\hline TCLEA & ND & ND & ND & 200 & 5.0 \\
\hline Vinyl chloride & ND & ND & 550 & 48 & ND \\
\hline trans-12DCE & ND & ND & 2,220 & 8,500 & ND \\
\hline TRCLE & ND & ND & 980 & 6,700 & 5.0 \\
\hline TCLEE & ND & ND & 420 & $\mathrm{ND}$ & ND \\
\hline
\end{tabular}

a Includes all parameters that were detected at least once. Metals analyzed but not detected: barium $(<300 \mu \mathrm{g} / \mathrm{L})$, chromium $(<10 \mu \mathrm{g} / \mathrm{L})$, mercury $(<0.2 \mu \mathrm{g} / \mathrm{L})$, and silver $(<25 \mu \mathrm{g} / \mathrm{L})$.

b $\mathrm{NA}=$ not analyzed.

c $\mathrm{ND}=$ not detected.

Source: Nemeth (1989). 
TABLE 2.9 Analytical Results for Selected Inorganic Compounds, TOC, and Metals in Groundwater from the Toxic Burning Pits, 1990

\begin{tabular}{|c|c|c|c|c|c|c|c|c|c|}
\hline Well & $\begin{array}{c}\text { Chloride } \\
(\mathrm{mg} / \mathrm{L})\end{array}$ & $\begin{array}{l}\text { Potassium } \\
(\mathrm{mg} / \mathrm{L})\end{array}$ & $\begin{array}{c}\text { TOC } \\
(\mathrm{mg} / \mathrm{L})\end{array}$ & $\begin{array}{c}\text { Arsenic } \\
(\mu \mathrm{g} / \mathrm{L})\end{array}$ & $\begin{array}{c}\text { Cyanide } \\
(\mu \mathrm{g} / \mathrm{L})\end{array}$ & $\begin{array}{c}\text { Lead } \\
(\mu g / L)\end{array}$ & $\begin{array}{l}\text { Nickel } \\
(\mu \mathrm{g} / \mathrm{L})\end{array}$ & $\begin{array}{l}\text { Selenium } \\
(\mu \mathrm{g} / \mathrm{L})\end{array}$ & $\begin{array}{c}\text { Zinc } \\
(\mu \mathrm{g} / \mathrm{L})\end{array}$ \\
\hline P2 & $<100$ & $<50$ & $<10$ & $\mathrm{ND}^{\mathrm{a}}$ & ND & ND & ND & 3.8 & ND \\
\hline P3 & $<100$ & 61.8 & 25 & 30.2 & ND & ND & 61.9 & ND & ND \\
\hline $\mathrm{P} 4$ & 390 & $<50$ & $<10$ & $\mathrm{ND}$ & ND & ND & ND & ND & 292 \\
\hline P9 & $<100$ & $<50$ & $<10$ & ND & ND & 124 & ND & ND & ND \\
\hline TH4 & $<100$ & $<50$ & $<10$ & ND & $\mathrm{ND}$ & ND & ND & 2.35 & ND \\
\hline JF51 & $<100$ & 140 & $<10$ & ND & 13.9 & ND & ND & ND & ND \\
\hline JF52 & $<100$ & $<50$ & $<10$ & ND & ND & ND & ND & ND & ND \\
\hline JF53 & $<100$ & $<50$ & $<10$ & $\mathrm{ND}$ & ND & ND & 440 & ND & ND \\
\hline JF61 & $<100$ & 98 & 160 & 8.03 & ND & ND & ND & ND & ND \\
\hline JF62 & $<100$ & $<50$ & 10 & ND & ND & ND & ND & ND & ND \\
\hline JF63 & 180 & $<50$ & 50 & 4.11 & ND & ND & ND & ND & ND \\
\hline JF71 & $<100$ & 79 & $<10$ & 3.32 & ND & ND & ND & ND & ND \\
\hline JF72 & $<100$ & $<50$ & 180 & ND & ND & ND & ND & 3.21 & ND \\
\hline JF73 & $<100$ & $<50$ & $<10$ & 5.52 & ND & ND & ND & ND & ND \\
\hline JF81 & 130 & $<50$ & $<10$ & ND & ND & ND & ND & ND & ND \\
\hline JF82 & $<100$ & 74.7 & 100 & 20.4 & 88 & ND & ND & ND & ND \\
\hline JF83 & 120 & $<50$ & $<10$ & 60 & ND & ND & ND & 6.18 & ND \\
\hline
\end{tabular}

a $\mathrm{ND}=$ not detected.

Source: USGS (1991). 
TABLE 2.10 Analytical Results for Selected VOCs in Groundwater from the Toxic Burning Pits Area, 1990

\begin{tabular}{|c|c|c|c|c|c|c|c|c|c|}
\hline \multirow[b]{2}{*}{ Well $^{\mathrm{a}}$} & \multicolumn{9}{|c|}{ VOC $^{b}$ Concentrations ( $\mu \mathrm{g} / \mathrm{L}$ ) } \\
\hline & 112TCE & 11DCE & 12DCE & C2H3CL & $\mathrm{C} 6 \mathrm{H} 6$ & CHCL3 & TCLEA & TCLEE & TRCLE \\
\hline P2 & 4.02 & $N^{c}$ & 10.2 & $\mathrm{ND}$ & ND & ND & 101 & ND & 440 \\
\hline $\mathrm{TH} 4$ & ND & $\mathrm{ND}$ & ND & ND & $\mathrm{ND}$ & ND & 3.73 & ND & ND \\
\hline JF53 & 110 & 8.04 & 850 & 132 & ND & ND & 3,500 & ND & 820 \\
\hline JF52 & 10 & ND & 420 & ND & $\mathrm{ND}$ & 2.2 & 34.3 & $\mathrm{ND}$ & 52 \\
\hline JF51 & ND & 3.79 & 430 & ND & ND & ND & ND & $\mathrm{ND}$ & 520 \\
\hline JF63 & ND & $\mathrm{ND}$ & 7.33 & $\mathrm{ND}$ & ND & 7.6 & ND & 17.6 & 600 \\
\hline JF62 & ND & ND & ND & ND & ND & ND & ND & ND & 2.7 \\
\hline JF61 & ND & ND & ND & $\mathrm{ND}$ & ND & ND & ND & ND & 1.8 \\
\hline JF73 & 67.3 & 6.81 & 7,150 & ND & ND & 2.9 & 340 & ND & 1,800 \\
\hline JF72 & $N D$ & ND & 32.6 & ND & ND & 1.9 & $\mathrm{ND}$ & ND & 4.5 \\
\hline JF71 & ND & ND & ND & ND & ND & 24 & ND & $\mathrm{ND}$ & 7.3 \\
\hline JF83 & 7,100 & 19 & 7,150 & 56.3 & 4.88 & 50 & 250 & 1,000 & 4,900 \\
\hline JF82 & ND & 30.1 & 210 & ND & ND & 5.6 & ND & 47.2 & 1,400 \\
\hline JF81 & 7,100 & ND & 34.6 & ND & ND & ND & 290 & $\mathrm{ND}$ & 230 \\
\hline
\end{tabular}

a TBP wells not listed contained no VOCs, or traces of 111TCE; C2H5CL, CCL4, CH3CL, and C6H5CL. No data for wells P1, P3, P4, JF43, JF41.

b Installation Restoration Data Management System acronyms are used for VOCs: $112 \mathrm{TCE}=1,1,2$-trichloroethane; $11 \mathrm{DCE}=1$,1-dichloroethylene; $12 \mathrm{DCE}=1,2$-dichloroethylene; $\mathrm{C} 2 \mathrm{H} 3 \mathrm{CL}=$ vinyl chloride; $\mathrm{C} 6 \mathrm{H} 6=$ benzene; CHCL3 = chloroform; TCLEA = 1,1,2,2-tetrachloroethane; TCLEE = tetrachloroethylene; and TRCLE = trichloroethylene.

c $\mathrm{ND}=$ not detected.

Source: USGS (1991). 
[JF82] and 7,100 $\mathrm{gg} / \mathrm{L} 112 \mathrm{TCE}$ in the confined aquifer [JF81]). Because the well screens monitoring the confined aquifer are at depths of $70 \mathrm{ft}$ or more (well JF81 is screened at a depth of 120-123 ft), VOC contamination extends more than $100 \mathrm{ft}$ deep.

Because TRCLE was detected most often, the TRCLE data were used to create a contour map of contamination in the surficial aquifer (Figure 2.15). Those contours show that a plume of contaminated groundwater extends south of the TBP area to the shore and, possibly, into the bay. Additional data on VOC concentrations in the groundwater at locations farther south and closer to the shore are needed to determine if the plume in the surficial aquifer extends into the bay.

Data for the single wells screened in the Potomac Group sediments (JF1 and JF2) indicate low concentrations of VOC contamination in the deeper strata. Well JF1 contained $2.25 \mu \mathrm{g} / \mathrm{L}$ 1,1,1-trichloroethane (111TCE) at a depth of 185-190 ft; well JF2 contained $6.7 \mu \mathrm{g} / \mathrm{L}$ TRCLE at 208-213 $\mathrm{ft}$. These values are questionable because one of the two blanks

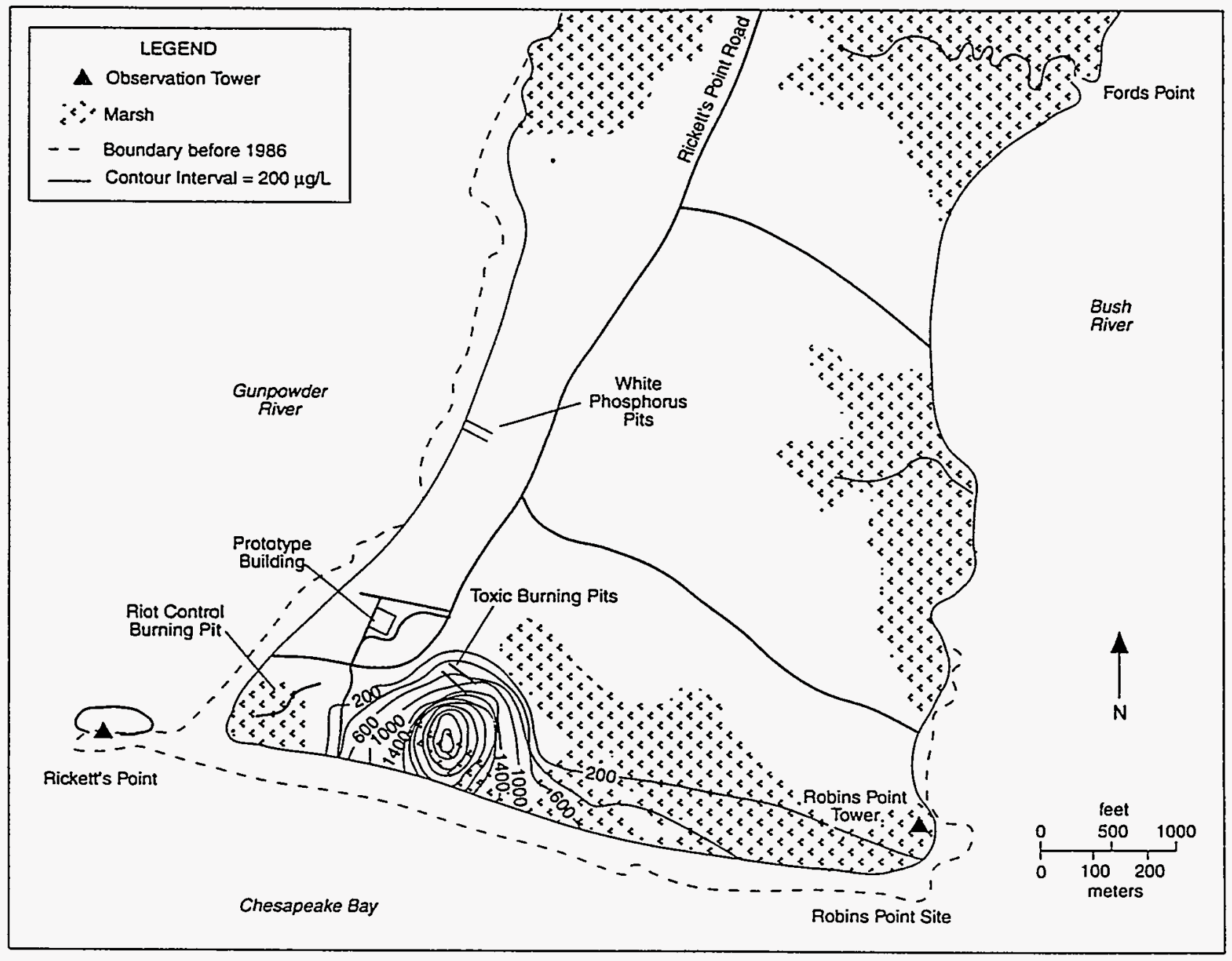

FIGURE 2.15 Contours of TRCLE Concentrations ( $\mu \mathrm{g} / \mathrm{L}$ ) in the Surficial Aquifer (contour interval $=200 \mu \mathrm{g} / \mathrm{L}$ ) (Source: Adapted from Hughes 1993) 
associated with the sampling event contained detectable concentrations of TCLEA, TCLEE, and TRCLE.

Groundwater samples from a few wells were analyzed for explosives and organosulfur compounds. Results are summarized in Table 2.11. The data indicate some contamination with organosulfur compounds (including degradation products of mustard) in the surficial aquifer downgradient from the TBP. The maximum concentration was $140 \mu g / L$ 1,4-dithiane in well P3 just north of the western end of the TBP. No organosulfur contamination was found in the middle or lower aquifers. Explosives-related compounds were also found in low concentrations (up to $226 \mu \mathrm{g} / \mathrm{L}$ nitrocellulose) in the water table and the lower aquifer. Because nitrocellulose is not soluble in water, this value is either lab error or due to suspended solids in the groundwater sample.

Concentrations of the radioactive species uranium, thorium-230, cesium-137, and strontium-90 were measured in monitoring wells P1, P3, P4, JF53, JF52, JF51, JF63, and JF73. Elevated concentrations of cesium-137 (up to $172 \mathrm{pCi} / \mathrm{L}$ ) and strontium-90 (up to

TABLE 2.11 Analytical Results for Organosulfur and Explosives-Related Compounds in Groundwater from the Toxic Burning Pits Area, 1990

\begin{tabular}{|c|c|c|c|c|c|}
\hline \multirow[b]{2}{*}{ Well } & \multicolumn{5}{|c|}{ Concentrations of Organosulfur Compounds ( $\mu \mathrm{g} / \mathrm{L}$ ) } \\
\hline & $\begin{array}{l}\text { 4-Chlorophenyl- } \\
\text { methsulfoxide }\end{array}$ & $\begin{array}{l}\text { 4-Chlorophenyl- } \\
\text { sulfone }\end{array}$ & 1,4-Dithiane & 1,4-Oxithiane & Thiodiglycol \\
\hline P3 & $\mathrm{ND}^{\mathrm{a}}$ & ND & 140 & ND & $N A^{b}$ \\
\hline $\mathrm{P} 4$ & ND & ND & 8.28 & ND & $\mathrm{NA}$ \\
\hline JF53 & ND & ND & 2.11 & ND & ND \\
\hline JF63 & ND & ND & 8.21 & 8.24 & 21 \\
\hline \multirow[t]{3}{*}{ JF83 } & ND & 20.5 & ND & ND & NA \\
\hline & \multicolumn{5}{|c|}{ Concentrations of Explosives-Related Compounds ( $\mu \mathrm{g} / \mathrm{L}$ ) } \\
\hline & $\mathrm{DNT}^{\mathrm{c}}$ & $\begin{array}{c}\text { Nitro- } \\
\text { benzene }\end{array}$ & $\begin{array}{l}\text { Nitro- } \\
\text { cellulose }\end{array}$ & $\mathrm{PETN}^{\mathrm{d}}$ & $\mathrm{RDX}^{\mathrm{e}}$ \\
\hline P9 & ND & ND & 226 & ND & 0.496 \\
\hline JF43 & ND & $\mathrm{ND}$ & 21.3 & $\mathrm{ND}$ & ND \\
\hline JF51 & ND & 0.0889 & ND & $\mathrm{ND}$ & ND \\
\hline JF63 & ND & ND & ND & 15.9 & ND \\
\hline JF73 & ND & ND & ND & ND & 1.18 \\
\hline
\end{tabular}

a $\mathrm{ND}=$ not detected.

b $N A=$ no data available.

c $\mathrm{DNT}=$ dinitrotoluene.

d PETN = penta-erythritol tetranitrate.

e $\mathrm{RDX}=$ hexahydro-1,3,5-trinitro-1,3,4-triazine.

Source: USGS (1991). 
$128 \mathrm{pCi} / \mathrm{L}$ ), measured as beta radiation, were found in wells P3, JF51, and JF73 (USGS 1991). If these values are confirmed by additional measurements, they would indicate the presence of radioactive contaminants.

In 1992, the USGS analyzed groundwater collected from wells in the TBP area (Figure 2.13) for VOCs (Table 2.12). The data indicate that VOCs are present in the three aquifers underlying J-Field (surficial unit, confining unit, and confined unit); that concentrations of TRCLE, TCLEE, TCLEA, 12DCE, and 112TCE have increased significantly since 1990 (see also Table 2.10); and that concentrations of 1,1-dichloroethylene (11DCE) have not been detected.

The highest VOC concentrations were found in well clusters JF5, 6, 7, and 8 in all three aquifers. The greatest increases in concentrations were found in JF83, which-monitors the surficial aquifer south of the main burning pits - TRCLE increased from 4,900 $\mathrm{\mu g} / \mathrm{L}$ in 1990 to $41,000 \mu \mathrm{g} / \mathrm{L}$ in 1992, TCLEE increased from $1,000 \mu \mathrm{g} / \mathrm{L}$ to $3,600 \mu \mathrm{g} / \mathrm{L}$, TCLEA increased from $250 \mu \mathrm{g} / \mathrm{L}$ to $260,000 \mu \mathrm{g} / \mathrm{L}$, and $12 \mathrm{DCE}$ increased from $7,150 \mu \mathrm{g} / \mathrm{L}$ to $12,000 \mu \mathrm{g} / \mathrm{L}$. Concentrations of 112TCE decreased from $7,100 \mu \mathrm{g} / \mathrm{L}$ in 1990 to $2,000 \mu \mathrm{g} / \mathrm{L}$ in 1992 (USGS 1992).

TABLE 2.12 Analytical Results for Selected VOCs in Groundwater Samples from the Toxic Burning Pits Area, 1992

\begin{tabular}{lrrrrrr}
\hline & \multicolumn{7}{c}{ VOC Concentrations ( $\mu$ /L) } \\
\cline { 2 - 7 } Well $^{\mathrm{a}}$ & 112TCE & 12DCE & C2H3CL $^{\mathrm{b}}$ & TCLEA & TCLEE & TRCLE \\
\hline P3 & ND $^{\mathrm{c}}$ & 980 & 600 & ND & 3,400 & 570 \\
P4 & 65 & 3,300 & ND & ND & ND & 3,600 \\
P9 & ND & ND & 10 & ND & ND & ND \\
JF53 & 290 & 10,000 & 95 & 4,900 & ND & 4,200 \\
JF52 & 1 & 140 & ND & 1 & ND & 3 \\
JF51 & ND & 210 & ND & ND & ND & 97 \\
JF63 & ND & 120 & ND & 75 & 130 & 4,400 \\
JF62 & ND & 4 & ND & ND & ND & 13 \\
JF61 & ND & 2 & ND & ND & 2 & 10 \\
JF73 & 90 & 920 & ND & 9,000 & 280 & 5,100 \\
JF71 & ND & ND & ND & 2 & ND & 3 \\
JF83 & 2,000 & 12,000 & ND & 260,000 & 3,600 & 41,000 \\
JF82 & ND & 190 & ND & ND & ND & 1,800 \\
JF81 & ND & 22 & ND & 5 & 3 & 220 \\
\hline
\end{tabular}

a TBP wells not listed contained no VOCs. No data were obtained for wells P1, P2, JF43, 42, 41, and JF72.

b $\mathrm{C} 2 \mathrm{H} 3 \mathrm{CL}=$ vinyl chloride.

c $\mathrm{ND}=$ not detected.

Source: USGS (1992). 


\subsubsection{Potential Pathways of Contaminant Migration}

Existing data indicate that the main pathway of contaminant migration at the TBP $A O C$ is movement through the vadose zone down into the groundwater and then transport by groundwater.

Contaminants are apparently moving from their source, down into the groundwater, and then downgradient into the marshes by surficial aquifer discharge or into the estuaries by groundwater upwelling, or to locations even farther downgradient.

The direction of groundwater movement in the Talbot aquifers appears to be away from the TBP AOC toward the low-lying marshes and under the Gunpowder and Bush rivers. However, the lateral gradients in the lower aquifers are quite small (USGS 1991). The vertical movement of groundwater appears to be down through the aquifers; however, offshore there may be upward flow from each of the three Talbot aquifers into the Gunpowder

and Bush rivers. Movement in the surficial and confined aquifers is affected by the tides (USGS 1991).

Surface water and associated sediment transport may play some role in contaminant migration in that surface runoff, particularly after intense storms, may carry dissolved and suspended contaminants from the contaminated areas into the marshes and estuaries. Surface water percolating through and leaching contaminated soils may be a major pathway by which contaminants move down into the groundwater, especially for metals and VOCs. Any contaminants that may have been present in the past in sufficient quantities to exist as free liquid in the soil would be expected to migrate down, independent of the presence of water.

Because of the generally humid conditions in the J-Field study area, wind transport of contaminated soil in areas with a good vegetative cover is expected to be minor. Diffusion of contaminated soil gas into the atmosphere and direct volatilization of contaminants from the soil are also expected to be minor release mechanisms. However, because portions of the TBP AOC are unvegetated or are sparsely covered with stressed vegetation, the air pathway may be significant and will be investigated. 


\section{FOCUSED FEASIBILITY STUDY TASKS}

In general, the FFS will be separated into two phases: (1) the development and screening of alternatives and (2) the detailed analysis of alternatives. Alternatives will be developed concurrently with the RI site characterization activities already in progress at the TBP AOC. This is an iterative process, with the results of the RI aiding in the development of alternatives and screening of technologies, and the range of alternatives guiding subsequent site characterization and treatability studies.

The FFS will consist of eight tasks:

- Task 1: Development of Remedial Action Objectives and Response Actions

- Task 2: Identification of Remedial Action Technologies and Assembly of Alternatives

- Task 3: Screening of Remedial Action Alternatives

- Task 4: Performance of Treatability Studies

- Task 5: Detailed Analysis of Alternatives

- 5.1 Detailed Development of Remaining Alternatives

- 5.2 Evaluation of Alternatives against Regulatory Criteria

- Task 6: Cost Analysis

- 6.1 Capital Costs

- 6.2 Operating and Maintenance Costs

- 6.3 Present Worth Analysis

- 6.4 Sensitivity Analysis

- 6.5 Cost Analysis Summary

- Task 7: Selection of Preferred Alternative

- Task 8: FFS Report Preparation

Each of these tasks is described in the following sections.

\subsection{TASK 1: DEVELOPMENT OF REMEDIAL ACTION OBJECTIVES AND RESPONSE ACTIONS}

\subsubsection{Development of Remedial Action Objectives}

Remedial action objectives to address contaminants of concern, potential exposure pathways, and remediation goals for this FFS will be developed on the basis of available information. The objectives will consist of specific goals for protecting human health and the 
environment. These goals will be developed with information from previous investigations and will address exposure routes, an acceptable contaminant level or range of levels for each exposure route (i.e., a preliminary remediation goal), and receptors. The goals will be as specific as possible without restricting the range of alternatives that can be developed.

\subsubsection{Development of General Response Actions}

General response actions (e.g., no action, treatment, containment, removal) will be developed to meet the objectives and goals. A list of feasible response actions will be developed to address specific problems and conditions. Table 3.1 lists examples of response actions and associated remedial technologies and process options to address sources of contamination at the TBP-AOC.

Currently available information indicates that the source of contamination at the TBP AOC is soil that has been contaminated by past disposal activities. If other sources are found, they will be integrated into the FFS. Because some simultaneous remediation of groundwater may be required, Table 3.1 also contains response action categories and associated technologies for groundwater contaminants. Remediation of the sources and the groundwater will be approached by development of limited remedial alternatives that will allow for quick action on the basis of limited design information, with larger-scale actions to follow.

Existing data will be used to identify site conditions that may limit or promote the use of certain response actions. Table 3.2 lists site characteristics that will be evaluated during this process. Response actions that are precluded by site characteristics or identified as not applicable on the basis of increased understanding of site conditions will be eliminated from further consideration. This process will include identification of waste characteristics that limit the effectiveness or applicability of certain technologies. Such waste characteristics include the following:

- Contaminant concentration,

- Toxicity of contaminant,

- Radiological characteristics,

- Chemical composition and characteristics,

- Persistence of contaminant,

- Mixture of contaminants, and

- Presence of unexploded ordnance (UXO) and/or CWAs. 
TABLE 3.1 Response Action Categories and Associated Technologies and Process Options

Response Action

Feasible Technologies

Feasible Process Options

Soil

No Action

May include some monitoring and

$\mathrm{TBD}^{\mathrm{a}}$

analysis

Restrict Access

Deed restrictions

TBD

Site fencing

TBD

Monitoring

Monitoring surface runoff

TBD

Migration Controls

Surface controls

Grading/revegetation

Containment

Soil cover

$N A^{b}$

Flood control

TBD

Capping

Synthetic membrane liner, clay with soil/vegetation cover, asphalt, multimedia (RCRA), chemical sealant, stabilizer

TBD

Removal/Treatment

Excavation; treatment on- or off-site

TBD

Ex-Situ Treatment

Chemical detoxification

TBD

Classification

TBD

Screening

Thermal destruction

Ceramic melter, rotary kiln, plasma arc, multiple hearth, molten salt reactor, pyrolysis

In-Situ Treatment

Microbial degradation

TBD

Vitrification

TBD

In-situ volatilization

TBD

Fixation/stabilization

TBD

Chemical detoxification

TBD

Soil aeration

TBD

Solvent extraction (soil washing)

TBD 
TABLE 3.1 (Cont.)

\begin{tabular}{|c|c|c|}
\hline Response Action & Feasible Technologies & Feasible Process Options \\
\hline \multicolumn{3}{|l|}{ Soil (Cont.) } \\
\hline \multirow[t]{2}{*}{ Removal/Disposal } & On-site landfill & NA \\
\hline & Off-site landfill & NA \\
\hline $\begin{array}{l}\text { Removal/Temporary } \\
\text { Storage }\end{array}$ & On-site interim storage facility & TBD \\
\hline \multicolumn{3}{|l|}{ Groundwater } \\
\hline No Action & $\begin{array}{l}\text { May include some monitoring } \\
\text { and analyses }\end{array}$ & TBD \\
\hline \multirow[t]{2}{*}{ Restrict Access } & Deed restrictions & NA \\
\hline & Site fencing & NA \\
\hline Monitoring & Groundwater monitoring & TBD \\
\hline \multirow[t]{4}{*}{ Containment } & Capping ${ }^{\mathbf{c}}$ & $\begin{array}{l}\text { Synthetic membrane liner, clay } \\
\text { with soil/vegetation cover, } \\
\text { multimedia (RCRA) }\end{array}$ \\
\hline & Vertical barriers & $\begin{array}{l}\text { Slurry walls, grout curtain, sheet } \\
\text { metal piling }\end{array}$ \\
\hline & Horizontal barriers & $\begin{array}{l}\text { Block displacement, grout } \\
\text { injection }\end{array}$ \\
\hline & Gradient control & TBD \\
\hline \multirow[t]{2}{*}{ Collection } & Extraction wells & TBD \\
\hline & Subsurface drains & TBD \\
\hline \multirow[t]{2}{*}{ Ex-Situ Treatment } & Biological treatment & $\begin{array}{l}\text { Activated sludge, trickling filter, } \\
\text { rotating biological contactor }\end{array}$ \\
\hline & Physical/chemical treatment & $\begin{array}{l}\text { Ion exchange, neutralization, } \\
\text { reverse osmosis, oxidation reduc- } \\
\text { tion, carbon adsorption, air } \\
\text { stripping, liquid/liquid extraction, } \\
\text { steam stripping }\end{array}$ \\
\hline \multirow[t]{3}{*}{ In-Situ Treatment } & Biodegradation & TBD \\
\hline & Activated carbon bed & TBD \\
\hline & Chemical detoxification & TBD \\
\hline
\end{tabular}


TABLE 3.1 (Cont.)

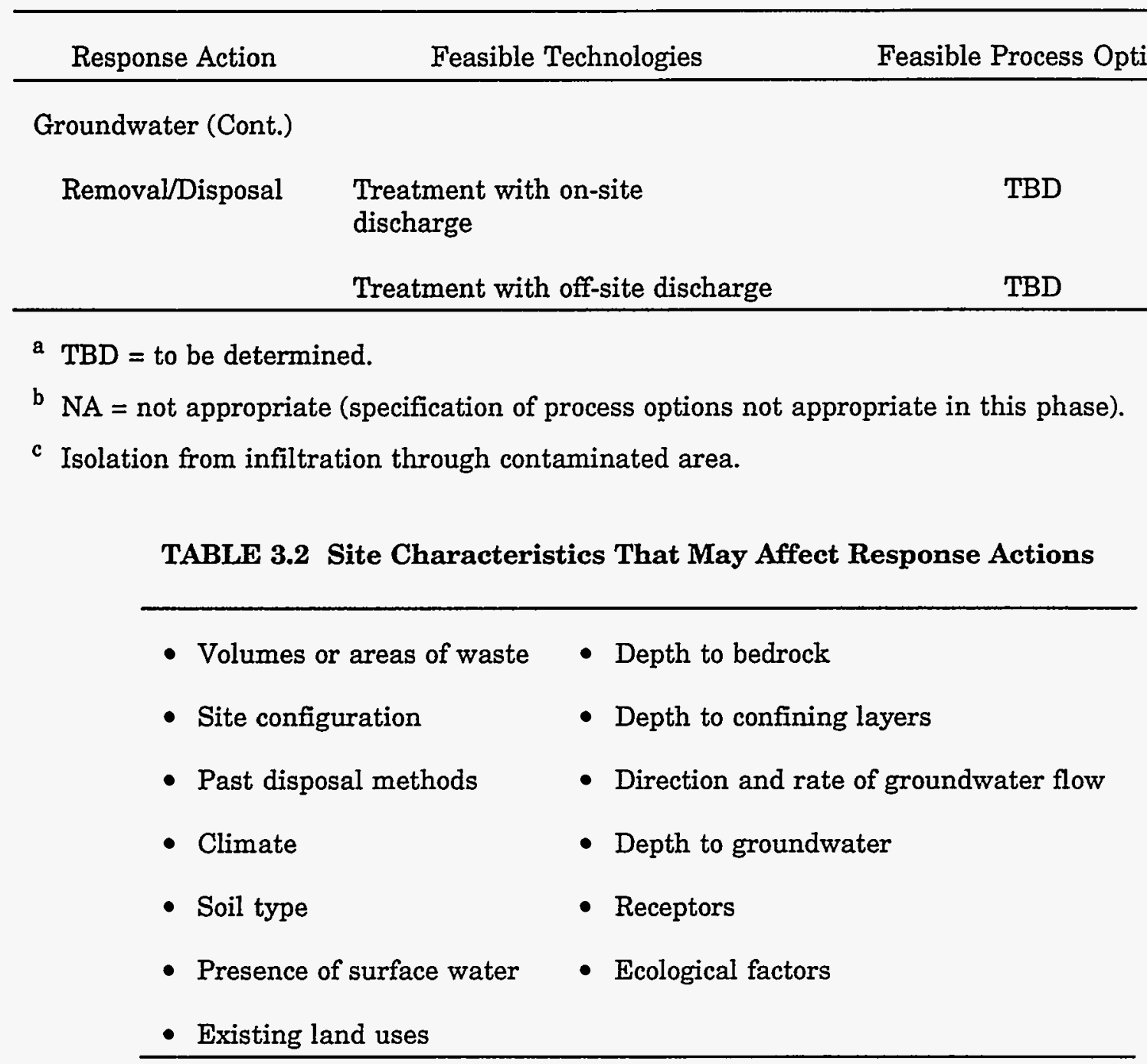

\subsection{TASK 2: IDEN'TIFICATION OF REMEDIAL ACTION TECHNOLOGIES AND ASSEMBLY OF ALTERNATIVES}

The CERCLA/SARA program permits remedial actions to be staged through multiple operable units, defined as discreet actions that comprise incremental steps toward the final remedy. The information developed in Task 1 (Section 3.1) will be used to assemble technologies ${ }^{3}$ into alternatives to remediate the TBP AOC as an operable unit through removal of the sources of contamination.

3 For this work plan, the term treatment technologies refers to general categories, such as thermal destruction or chemical treatment. The term process options refers to specific processes within a technology, e.g., the technology of thermal destruction includes incinerators, and process options within this technology deal with specific incinerator types (rotary kiln, fluidized bed, etc.). 
Operable units include interim actions (e.g., pumping and treating groundwater to retard plume migration) that must be followed by subsequent actions to fully address the scope of the problem (e.g., a final groundwater operable unit that defines the remediation goals and restoration time-frame for the site). This approach may be taken because of the need to respond to a pressing problem that will worsen if unaddressed, or because of an opportunity to undertake a limited action that will achieve significant risk reduction quickly. The concept of dividing remedial actions into operable units incorporates consideration of the interrelationship of site problems and recognizes the need or desire to initiate actions quickly when appropriate. Where the problems are reasonably separable, this phased response, implemented through operable units, promotes a more rapid reduction of risk.

For the TBP AOC, operable units will be identified and alternatives will be assembled by linking response actions with feasible process options that are considered applicable for the unit-specific conditions. In this case, applicability is based primarily on the remedial action objectives. The alternatives will be defined with respect to size and configuration of the representative process options; time for remediation; rates of flow or treatment; spatial requirements; distances for disposal; and required permits, imposed limitations, and other factors necessary to evaluate and compare the alternatives.

As mandated by SARA, three principal categories of alternatives are to be considered: (1) containment with treatment, (2) containment without treatment, and (3) no action. The first category will include alternatives that encompass a range of options in which treatment is used to reduce the toxicity, mobility, or volume of wastes, but that vary in the degree to which long-term management of residuals or untreated waste is required. The second category will include one or more alternatives that incorporate containment with little or no treatment. The no-action alternative may include some site monitoring, but alternatives incorporating administrative or access controls (deed restrictions, site fencing) will be presented as limited action alternatives.

The universe of potentially applicable technology types and process options will be reduced in an initial screening through evaluation of technical feasibility (also referred to as implementability), effectiveness, and relative cost. The criteria for this initial screening will be applied only to technologies and the general response actions they are intended to satisfy, not to the site as a whole. Evaluation of technical feasibility will focus primarily on whether the technologies and process options will meet remedial action objectives.

Cost considerations will be limited to relative capital costs and operating and maintenance (O\&M) costs. Costs will be estimated on the basis of engineering judgment, with each option evaluated as high, medium, or low cost relative to other options in the same technology. During this phase, only costs associated with different general technology types will be considered.

Evaluation of technology effectiveness will include comparison of technology types and the potential effectiveness of process options to: (1) handle the estimated areas or volumes of waste and meet remediation goals, (2) mitigate potential impacts to human health and the environment during construction and implementation, and (3) perform reliably with 
respect to the contaminants and conditions at the site. Additional site data may have to be collected for some media to adequately evaluate effectiveness.

\subsection{TASK 3: SCREENING OF REMEDIAL ACTION ALTERNATIVES}

Information developed in Tasks 1 and 2 will be screened to limit the number of alternatives evaluated during more detailed phases of the FFS. This screening process will include refinement of the initial alternatives on the basis of any new information that becomes available, the risk assessment, and other site investigations. In this more in-depth phase, each alternative will be evaluated with respect to feasibility, effectiveness, and cost. Alternatives also will be evaluated to ensure that they will protect human health and the environment relative to potential pathways of concern and areas of the site being addressed as separate operable units. If practicable, the range of treatment and containment technologies initially developed will be preserved; however, if alternatives within a portion of this range are not feasible, they will be eliminated.

Evaluation of the feasibility (implementability) of alternatives will consider both technical and administrative feasibility. The evaluation of technical feasibility will address the ability to construct, reliably operate, meet technology-specific regulations, and effectively monitor components into the future. Evaluation of administrative feasibility will consider the ability to comply with the substantive requirements of any permits issued; availability of treatment, storage, and disposal services; and the requirements for, and availability of, specific equipment and technical specialists.

In terms of effectiveness, each alternative will be evaluated for its ability to: (1) protect human health and the environment; (2) reduce toxicity, mobility, or volume (i.e., to effect changes in one or more characteristics of the hazardous substance that, as a result of treatment, decrease the inherent threats or associated risks); and (3) perform reliably with respect to the contaminants and conditions at the site. These elements will be evaluated for the construction and implementation periods (short-term effectiveness) and for the period after the remedial action is complete (long-term effectiveness).

Although cost factors are not as important as other criteria for selection of alternatives under CERCLA, they will be considered whenever the cost of an alternative far exceeds (by at least an order of magnitude) that of other alternatives without a demonstrated and equivalent difference in protectiveness, implementability, and reliability. Cost estimates will be developed for use in screening activities to the extent that comparisons of alternatives are possible. The estimates will be based on standard cost-estimating data, including cost curves, generic unit costs, vendor information, conventional cost-estimating guides, and estimates derived for similar sites (modified for site-specific information). 


\subsection{TASK 4: PERFORMANCE OF TREATABILITY STUDIES}

Treatability studies will be performed, as appropriate, to collect additional data on technologies identified during the alternative development process and to determine the applicability of specific remedial technologies to site conditions and problems. The sufficiency of existing data to evaluate alternatives will be assessed to determine the need for treatability studies. Where possible, additional data needs will be identified through an expanded literature search with the following objectives:

- Determine whether the performances of the technologies under consideration have been sufficiently documented on similar wastes;

- Obtain information on relative costs, applicability, removal efficiencies, O\&M requirements, and implementability of the technologies; and

- Determine the testing requirements for conducting bench or pilot studies.

The decision to conduct treatability studies will ultimately be made by weighing the cost and time required to complete an investigation against the potential value of the information in resolving uncertainties associated with the selection of an alternative. Should treatability studies be required, a testing plan will be developed to identify the types of studies and their goals, the level of effort needed, and a schedule for completion. The datamanagement guidelines will be submitted to the Directorate of Safety, Health, and Environment, Aberdeen Proving Ground, for review and approval and subsequent submittal to the EPA.

During the testing, all management and quality control review activities will be implemented to ensure the quality of the data. Upon completion of the testing, the results will be evaluated to assess the technologies with respect to the goals identified in the test plan. A report summarizing the testing program and its results will be presented in the final FFS report.

\subsection{TASK 5: DETAILED ANALYSIS OF ALTERNATIVES}

\subsubsection{Subtask 5.1: Detailed Development of Remaining Alternatives}

The detailed development of the alternatives remaining after the screening described above will provide the information needed to complete the final evaluation and selection of the preferred alternative. Examples of development information include the following:

- The components of treatment and disposal technologies will be described to provide an understanding of the features and functions of the technologies. 
- Special engineering considerations required to implement an alternative will be identified (e.g., treatability studies for in-situ treatment, benchscale testing for containment options, or pilot treatment facilities for on-site treatment).

- Proposed methods and costs, associated physical and legal issues, and compliance with applicable or relevant and appropriate requirements (ARARs) will be discussed.

- Operation, maintenance, and monitoring requirements will be addressed (e.g., frequency, complexity, cost, and availability of labor and materials necessary for effective operations of the technologies).

- Alternatives involving off-site disposal that may impose special requirements for implementation will be addressed. The disposal needs and transportation plans, such as zoning clearances, local permits, and appropriate actions to comply with state and federal regulations, will be identified.

- Safety requirements for implementation of alternatives will address both off-site and on-site issues. Factors relative to the health and safety of site personnel, nearby populations, and the environment will be identified for both short-term and long-term operational periods.

\subsubsection{Subtask 5.2: Evaluation of Alternatives against Regulatory Criteria}

Nine evaluation criteria, some of which are related to human health evaluation and risk, have been developed under the CERCLA program to address statutory requirements, as well as additional technical and policy considerations that have proven to be important to the process of selecting among remedial alternatives. The criteria are (1) overall protectiveness; (2) compliance with ARARs; (3) long-term effectiveness and permanence; (4) reduction of mobility, toxicity, or volume through treatment; (5) short-term effectiveness; (6) implementability; (7) cost; (8) state acceptance; and (9) community acceptance. These evaluation criteria will be use to conduct a detailed analysis and to select an appropriate remedial action for the TBP operable unit. The results of the evaluation will be arrayed so that alternatives can be compared and key trade-offs identified.

The first two criteria - overall protectiveness and compliance with ARARs - are considered threshold determinations and must be met before a remedy can be selected. Evaluation of the overall protectiveness of an alternative will focus on how well it will achieve protection over time and reduce site risks, and how it will become part of the sitewide remedy.

To satisfy the relevant NCP remedy-selection criteria, an assessment of the overall protectiveness and attainment of ARARs will be developed for each alternative. That 
assessment will determine how well the risks posed by each pathway associated with the operable unit are eliminated, reduced, or controlled through treatment, engineered controls, or institutional controls. A detailed analysis of the environmental effects will not be conducted if those effects are not within the scope of the alternative under consideration. Factors that will be considered include (1) effects on environmentally sensitive areas, (2) compliance with regulations, (3) short- and long-term effects, and (4) irreversible commitment of resources. Any known or potential environmental problems previously identified that are not addressed by the remedial alternative will be clearly described.

The evaluation of overall protectiveness criteria will address the effects (both longand short-term) of each alternative under consideration. Each alternative will be assessed with regard to how well it mitigates long-term exposure to any residual contamination and protects human health both during and after completion of the remedial action. The assessment will describe the levels and characteristics of contaminants, potential exposure routes, and potentially affected populations. In general, the evaluation of each alternative will consider both the expected adverse effects and the beneficial effects, such as changes in the release of contaminants, resultant environmental conditions, improvements in the resources, and improvements in the biological environment.

The level of detail in this evaluation will depend on the degree of actual or potential damage to the environment providing the impetus for response. The detail must be adequate to compare the expected environmental benefits of different alternatives and to determine the effects of construction and operation. Because remedial activities may themselves have a wide range of environmental effects, findings will be presented in such a way as to permit comparison of the environmental effects of the different alternatives on specific resources (e.g., hydrological, geological, biological, land use).

The associated mitigative measures to be implemented will be analyzed for any alternative that appears to have significant inevitable or irreversible environmental effects. The analysis will take into consideration the technology to be used, the associated cost, and the mitigating effects.

To determine if an alternative satisfies ARAR criteria, the effects of federal, state, and local requirements, regulations, and other institutional considerations relative to the design, operation, and timing of each alternative will be evaluated. These results will be presented as part of the noncost criteria analysis in the final report. All ARARs and other standards to be considered will be identified.

The next five criteria are primary balancing criteria: long-term effectiveness and permanence; reduction of mobility, toxicity, or volume through the use of treatment; shortterm effectiveness; implementability; and cost. Risk will be an important factor in the analysis of effectiveness and permanence. The analysis will evaluate the residual risk at the site after response objectives have been met. The primary focus will be on effectiveness of the controls to manage risk posed by treatment residuals or any untreated wastes that may remain. The evaluation will also consider the potential impacts on human health and the environment if the remedy fails. 
The last two criteria - state acceptance and community acceptance - are considered modifying criteria and do not include risk information. These criteria will be evaluated after public comments are received on the RI/FS report and the proposed plan. The acceptance criteria will be addressed once a final decision is made and the record of decision (ROD) is being prepared.

The FFS will satisfy the statutory requirements for the remedial actions that will be addressed in the ROD. Those provisions require that the remedial actions:

- Be protective of human health and the environment;

- Attain ARARs or provide grounds for invoking a waiver;

- Be cost-effective;

- Utilize permanent solutions and alternative treatment technologies, or resource recovery technologies, to the maximum extent practicable; and

- Satisfy the preference for treatment that reduces toxicity, mobility, or volume as a principal element (or provide an explanation as to why it does not).

Analyses of individual alternatives will include (1) a technical description that outlines the waste management strategy involved and identifies the key ARARs associated with each alternative and (2) a discussion that profiles the performance of the alternative with respect to each of the evaluation criteria. After the individual analyses are complete, the alternatives will be compared and contrasted relative to each of the evaluation criteria.

\subsection{TASK 6: COST ANALYSIS}

The cost analysis for each alternative and its component technologies will include consideration of site-specific factors identified in available information and determined during development of the alternative. Common sources for these cost estimates include vendors, estimates for similar projects, and standard costing guidance documents. This evaluation will include the following factors: cost estimation (estimation of capital costs and O\&M costs); present-worth analysis (calculation of annual costs and present worth on the basis of estimated costs); and summary of the costs of alternatives (summary of cost data, including total costs and distribution of costs over time).

\subsubsection{Subtask 6.1: Capital Costs}

Capital costs consist of direct (construction) and indirect (nonconstruction and overhead) costs. Direct costs include expenditures for equipment, labor, and installation materials. Capital costs that must be increased in future years as part of the remedial action alternatives will be identified and noted for the year in which they will occur. Indirect costs 
include expenditures for engineering, financial, and other services that are not part of actual installation activities but that are required to complete the installation of the technologies constituting the alternative. The following are examples of direct and indirect capital costs:

- Construction - materials, labor, and equipment;

- Equipment - remedial action and service equipment;

- Land and site development - purchase of land and preparation of the site;

- Buildings and services - utility connections, process and nonprocess buildings, purchased services;

- Disposal - transporting and disposing of wastes;

- Engineering - administration, construction supervision, design, treatability testing;

- License and permits - administrative costs to obtain building and operating permits;

- Start-up - activities to ensure that the systems are operational; and

- Contingency fund - funds for unforeseen circumstances (e.g., weather, unexpected levels of contamination).

\subsubsection{Subtask 6.2: Operating and Maintenance Costs}

Operating and maintenance costs are postconstruction expenditures necessary to ensure the continued effectiveness of a remedial action. Typical O\&M costs include the following:

- Labor - wages, salaries, training, and overhead;

- Maintenance materials and labor - routine maintenance and equipment replacement;

- Auxiliary materials and energy - chemicals, electricity, water, sewer, fuel;

- Purchased services - sampling, laboratory; 
- Insurance, taxes, and licenses - accident and liability insurance, real estate taxes, technology license fees; and

- Periodic site reviews - required at least every five years as long as wastes are present.

\subsubsection{Subtask 6.3: Present-Worth Analysis}

Present-worth analysis will be used to evaluate expenditures that occur over different time periods by discounting all future costs to the present. A discount rate of $3 \%$ before taxes and after inflation will be assumed in the present-worth analysis. This rate represents the average rate of return on private investment. Costs in each planning year will be estimated in constant dollars, representing the general purchasing power at the time of construction. The period of performance will not exceed 30 years for the purpose of detailed feasibility analysis.

\subsubsection{Subtask 6.4: Sensitivity Analysis}

After the present-worth analysis of each alternative is completed, sensitivity analyses will be used to evaluate each cost for the effects of variations in assumptions. This analysis will assess how variations in specific assumptions about the design, implementation, operation, discount rate, and effective life of an alternative can affect its estimated cost. The sensitivity analysis will be used to optimize the design of an alternative, particularly when design parameters are interdependent (e.g., treatment plant capacity for contaminated groundwater and the length of the period of performance).

\subsubsection{Subtask 6.5: Cost Analysis Summary}

Data developed in the cost estimation and present-worth analysis will be used in a summary table to describe the alternative. To provide a common basis for comparison of costs, the following elements will be included in the summary: (1) total capital cost, (2) total cost of implementation, (3) present-worth costs, and (4) cash flow over the life of the alternative (including O\&M costs and identification of future capital costs).

\subsection{TASK 7: SELECTION OF PREFERRED ALTERNATIVE}

To provide a basis for selection of a preferred alternative, the analysis of the alternatives will discuss the individual criteria assessment and include a comparative analysis to evaluate the relative performance of each alternative.

The individual alternative assessments will provide data on technology components, quantities of hazardous materials handled, time required for implementation, process sizing, implementation requirements, and assumptions. The significant ARARs for each alternative 
will be integrated into the discussion. A summary table will highlight the assessment of each alternative with respect to the nine evaluation criteria. The relative performances of the alternatives will be compared relative to each evaluation criterion. That analysis will include a discussion of the strengths and weaknesses of the alternatives (with respect to each criterion) and how reasonable variations of key uncertainties could change the expectations of relative performances. Substantive differences among alternatives will be identified.

The technology assessments and risk management judgments will be used to rank the alternatives and identify those alternatives projected to attain or exceed the requirements

of the evaluation criteria. The comparative advantages and disadvantages of each alternative will be presented.

\subsection{TASK 8: REPORT PREPARATION}

An FFS report will be prepared to document project activities carried out during implementation of the FFS at the TBP AOC. The report will include an overview of the site background information and the compliance process; and summarize cleanup criteria derived from the preliminary results (if available) of the baseline risk assessment and ecological risk assessment (since these risk assessments will not be complete at the time of the FFS). For each task, the report will outline the criteria used to perform the task and rationale for the conclusions reached. All data, including new data obtained from the RI, the baseline·risk assessment, and the ecological risk assessment, will be included.

A preliminary draft FFS report will be prepared and submitted to the DSHE for review and comment. After Argonne National Laboratory (ANL) has incorporated all comments received from the DSHE, a review draft version of the report will be submitted to other agencies designated by the DSHE. Draft final and final reports will be prepared on the basis of all comments received. 


\section{REPORT PREPARATION}

\subsection{DRAFT FOCUSED FEASIBLITY STUDY REPORT}

A draft FFS report documenting all FFS activities was submitted in September 1994. A draft final version of this report will be delivered in February 1995. Table 4.1 presents the general outline of the report; minor modifications may be made as appropriate. The contents of the report are discussed in the following sections.

\subsubsection{Section 1: Introduction}

Section 1 will discuss the purpose and scope of the FFS and the FFS report. It will also provide an overview of the environmental compliance process for the project and the report organization.

\subsubsection{Section 2: Site Background}

Section 2 will present the site background relevant to the analysis of remedial action alternatives and management of the site, including (1) a brief description of the operational history and environmental setting of J-Field; (2) a summary of contamination emphasizing key information from the RI report; (3) an overview of all environmental activities conducted at J-Field to date; and (4) a brief discussion of human health and environmental impacts that might occur in the absence of remedial action, using data from the baseline risk assessment (which includes an ecological risk assessment).

\subsubsection{Section 3: Remedial Action Objectives}

Section 3 will identify (1) the objectives of the remedial action at J-Field; (2) environmental standards, identified as ARARs; (3) the process for developing cleanup criteria; and (4) cleanup criteria for all contaminated media being remediated.

\subsubsection{Section 4: Identification and Screening of Technologies}

Section 4 will identify and screen potential response technologies for managing $\mathrm{J}$ - Field and the criteria used for the evaluation.

\subsubsection{Section 5: Development and Screening of Preliminary Alternatives}

Section 5 will document the development and screening of preliminary alternatives -and the criteria used for combining sets of technologies into alternatives. It will present the 
TABLE 4.1 Generalized Outline of FFS Report

1 Introduction

1.1 Background

1.2 Purpose and Scope

1.3 Overview of the Environmental Compliance Process

1.4 Report Organization

2 Site Background

2.1 Site History

2.2 Site Description

2.2.1 Topography

2.2.2 Soils and Geology

2.2.3 Surface Water

2.2.4 Groundwater

2.2.5 Climate and Meteorology

2.2.6 Ecology

2.2.7 Land Use and Demography

2.3 Nature and Extent of Contamination

2.4 Environmental Activities at J-Field

2.4.1 Remedial Investigation

2.4.2 Baseline Risk Assessment

2.4.3 Interim Action at the Toxic Burning Pits

2.5 Summary of Site Risks

2.5.1 Human Health Risk Assessment

2.5.2 Ecological Risk Assessment

3 Remedial Action Objectives

3.1 Overall Remedial Action Objectives

3.2 Environmental Standards and Guidelines

3.3 General Process for Developing Cleanup Criteria

3.4 Cleanup Criteria

4 Identification and Screening of Technologies

4.1 Criteria for Identifying and Screening Technologies

4.2 Technology Identification and Screening

4.3 Potentially Applicable Technologies

5 Development and Screening of Preliminary Alternatives

5.1 Criteria for Developing Preliminary Alternatives

5.2 Identification of Preliminary Alternatives

5.3 Criteria for Screening Alternatives

5.4 Screening of Preliminary Alternatives

5.5 Screening Summary and Identification of Final Alternatives 
TABLE 4.1 (Cont.)

6 Detailed Analysis of Alternatives

6.1 Alternative 1

6.1.1 Overall Protection of Human Health and the Environment

6.1.2 Compliance with ARARs

6.1.3 Long-Term Effectiveness

6.1.4 Reduction of Toxicity, Mobility, or Volume through Treatment

6.1.5 Short-Term Effectiveness

6.1.6 Implementability

6.1.7 Cost

7 Comparative Analysis of Alternatives

7.1 Threshold Criteria

7.1.1 Overall Protection of Human Health and the Environment

7.1.2 Compliance with ARARs

7.2 Primary Balancing Criteria

7.2.1 Long-Term Effectiveness and Permanence

7.2.2 Reduction of Toxicity, Mobility, or Volume through

Treatment

7.2.3 Short-Term Effectiveness

7.2.4 Implementability .

7.2.5 Cost

7.3 Comparative Summary

8 References

objective of the alternative (e.g., source control or mitigation of contaminant migration), identify key features, describe each alternative, and summarize the evaluation of the alternative. This section will also include (1) associated control, treatment, and disposal requirements; (2) special engineering, safety, and other features that affect the feasibility of the alternative; (3) operation, maintenance, and monitoring requirements; and (4) aspects of the contamination that the alternative will address.

\subsubsection{Section 6: Detailed Analysis of Alternatives}

Section 6 will present a detailed analysis of each alternative relative to the nine EPA evaluation criteria. The discussion of protectiveness and compliance with ARARs will focus on how well each alternative achieves protection over time and reduces risks identified for each operable unit. The technical discussion will focus on the effectiveness, implementability, and cost of each alternative. The discussion of modifying factors will present regulatory and community acceptance issues for each alternative and will address impacts of those issues on the selection of an alternative. The cost analysis will summarize the estimated costs for each alternative, review the main cost items, and discuss other important considerations in the cost analysis. The cost analysis will also include (1) costing methodology; (2) capital 
costs; (3) operation and maintenance costs; (4) present-worth analysis; (5) phasing of the work and its impact on cost, as appropriate; and (6) distribution of costs over time.

\subsubsection{Section 7: Comparative Analysis of Alternatives}

Section 7 will present a comparative analysis of the alternatives, describing the relative strengths and weaknesses of the alternatives with respect to each of the nine evaluation criteria. The effects of variations in key uncertainties on the relative performance of the alternatives will also be discussed. A preferred alternative will be selected and described in detail.

Tables and figures will be used to summarize important features of the alternatives. The advantages and disadvantages of each alternative will be listed for comparison. The preferred alternative and the rationale for its selection will be presented at the end of the section. The discussion will include, as appropriate (1) a review of what will and will not be accomplished by implementation of the preferred alternative; (2) special engineering considerations and studies required during the final design stage; (3) operating, maintenance, and monitoring requirements; (4) off-site disposal requirements and transportation plans; (5) safety requirements for implementation; and (6) integration of the alternative into the sitewide remedy.

\subsection{OTHER REPORTS AND COMMUNICATIONS}

\subsubsection{Monthly Progress Reports}

Monthly reports will be submitted to the DSHE, Aberdeen Proving Ground, in part to obtain input and agreement on the technologies considered. The reports will contain information about the following items:

- Status of work and the progress to date,

- Percentage of work completed and the status of the schedule,

- Problems encountered and the corrective actions taken,

- The activities in progress,

- The activities planned for the next reporting period,

- Any changes in key project personnel,

- Budget information, and

- Projection of expenditures needed to complete the project. 
These frequent communications will streamline the process and promote cost savings by providing technical reviewers with opportunities to comment early in the decision-making process - before a commitment is made to conduct in-depth study. Through these comments, the screening decisions, assembly of technologies into alternatives, and identification of data deficiencies will be developed with a broader scope of information.

\subsubsection{Responsiveness Summary}

The draft final FFS report will be revised to incorporate comments received from the sponsor, the public and regulatory agencies. A responsiveness summary will present the comments received and the actions taken to address the comments. After final review by the DSHE, the final FFS report will be prepared and delivered. 


\section{REFERENCES}

Benioff, P., et al., 1995a, Remedial Investigation Work Plan for J-Field, Aberdeen Proving Ground, Maryland, ANL/EAD/TM-40, Argonne National Laboratory, Argonne, Ml., March.

Benioff, P., et al., 1995b, Remedial Investigation Sampling and Analysis Plan for J-Field, Aberdeen Proving Ground, Maryland, Volume 1: Field Sampling Plan, ANL/EAD/TM-38, Vol. 1, Argonne National Laboratory, Argonne, Ml., March.

COE - see U.S. Army Corps of Engineers.

EPA - see U.S. Environmental Protection Agency.

Hughes, W.B., 1992, letter with attachment from Hughes (U.S. Geological Survey, Towson, Md.) to J. Wrobel (U.S. Army, Aberdeen Proving Ground, Md.), June 19.

Hughes, W.B., 1993, Hydrogeology and Soil-Gas at J-Field Aberdeen Proving Ground, Maryland, U.S. Geological Survey Water-Resources Investigations Report 92-4087, prepared in cooperation with the U.S. Army, Aberdeen Proving Ground Support Activity, Environmental Management Division, Towson, Md.

Mazelon, M., 1993, Letter from Mazelon (Chief Engineer, Roy F. Weston, Inc., Aberdeen Proving Ground, Md.) to R. Rizzieri (U.S. Corps of Engineers, Aberdeen Proving Ground, Md.), Feb. 26.

Nemeth, G., 1989, RCRA Facility Assessment, Edgewood Area, Aberdeen Proving Ground, MD, 39-26-0490-90, U.S. Army Environmental Hygiene Agency, Waste Disposal Engineering Division, Aberdeen Proving Ground, Md., Nov.

Prasad, S., et al., 1995, Remedial Investigation Sampling and Analysis Plan for J-Field, Aberdeen Proving Ground, Maryland, Volume 2: Quality Assurance Project Plan, ANL/EAD/TM-38, Vol. 2, Argonne National Laboratory, Argonne, Ml., March.

Princeton Aqua Science, 1984, Munitions Disposal Study, prepared for Department of the Army, Directorate of Engineering and Housing, Environmental Management Office, Aberdeen Proving Ground, Md.

Sonntag, W., 1991, Sampling and Analysis Plan for the Investigation of Ground-Water Contamination at J-Field, Aberdeen Proving Ground, Maryland, draft report, U.S. Geological Survey, Reston, Va.

U.S. Army Corps of Engineers, 1923, "Gunpowder Neck, Maryland, Grid Zone A," Terrain Map 26547531/46; War Department, U.S. Army, Washington, D.C. 
U.S. Environmental Protection Agency, 1988, Guidance for Conducting Remedial Investigations and Feasibility Studies under CERCLA, Interim Final, report EPA/540/G89/004, Office of Emergency and Remedial Response, Washington, D.C.

U.S. Environmental Protection Agency, 1992, unpublished data.

U.S. Environmental Protection Agency and U.S. Department of the Army, 1990, Federal Facility Agreement, Aberdeen Proving Ground, Administration Docket No. III-FCA-CERC-004, March.

USGS - see U.S. Geological Survey.

U.S. Geological Survey, 1991, Phase II Workplan and Field Sampling Plan Update for the Remedial Investigation at J-Field Aberdeen Proving Ground, Maryland, prepared by the USGS, Water Resources Division, Towson, Md., for the U.S. Army, Aberdeen Proving Ground Support Activity, Environmental Management Division, Aberdeen, Md.

U.S. Geological Survey, 1992, unpublished data.

Weston, 1992, Characterization and Interim Remediation of J-Field at Edgewood Area Aberdeen Proving Ground, Maryland, Draft Report, Roy F. Weston, Inc., for U.S. Army Corps of Engineers, Baltimore District. 


\section{LIST OF PREPARERS}

This Focused Feasibility Study Work Plan was prepared for the U.S. Army, Directorate of Safety, Health, and Environment, Aberdeen Proving Ground, by the Environmental Assessment Division of Argonne National Laboratory (ANL). The following ANL staff members have contributed to the preparation of this work plan.

\begin{tabular}{|c|c|c|}
\hline Name & Education/Experience & Contribution \\
\hline Louis Martino & $\begin{array}{l}\text { M.S., environmental toxicology; } \\
15 \text { years experience in environ- } \\
\text { mental assessment; J-Field project } \\
\text { manager. }\end{array}$ & $\begin{array}{l}\text { Section } 1 \text { Introduction } \\
\text { Section } 2 \text { Environmental } \\
\text { Conditions }\end{array}$ \\
\hline Carole Biang & $\begin{array}{l}\text { B.S., chemical engineering; } 15 \text { years } \\
\text { experience in management and } \\
\text { remediation of hazardous waste } \\
\text { sites; environmental assessment } \\
\text { lead author. }\end{array}$ & $\begin{array}{l}\text { Section } 1 \text { Introduction } \\
\text { Section } 3 \text { Focused } \\
\text { Feasibility Study Tasks } \\
\text { Section } 4 \text { Report } \\
\text { Preparation }\end{array}$ \\
\hline Paul Benioff & $\begin{array}{l}\text { Ph.D., nuclear chemistry; } 17 \text { years } \\
\text { experience in theoretical chemistry; } \\
16 \text { years experience in environ- } \\
\text { mental assessment. }\end{array}$ & $\begin{array}{l}\text { Section } 2 \text { Environmental } \\
\text { Conditions } \\
\text { Section } 3 \text { Focused } \\
\text { Feasibility Study Tasks }\end{array}$ \\
\hline Terri Patton & $\begin{array}{l}\text { M.S., geology; } 6 \text { years experience in } \\
\text { radiochemical analysis; } 5 \text { years } \\
\text { experience in environmental assess- } \\
\text { ment. }\end{array}$ & $\begin{array}{l}\text { Section } 2 \text { Environmental } \\
\text { Conditions } \\
\text { Section } 4 \text { Report } \\
\text { Preparation }\end{array}$ \\
\hline
\end{tabular}


